\title{
Index for Volume 101
}

AUTHOR AND SUBJECT INDEX. Pages indicating errata are in italic.

14-3-3-proteins, Bradyrhizobium japonicum on soybean and, S150

Aba, D., S232

Abad, G. Z., S136

Abad, J., S102

Abang, M., S135

Abawi, G., S257

Abawi, G. S., S1

Abbas, H., S1

Abbasi, P. A., S1

Abdelkarim, M., S2

Abd-Elmagid, A. W., S2

Abdo, Z., S171

Abdollahi, H., S60

Abdullah, S., S85, S192

Abdulsalam, K. S., S3

Abel, C., S1

Abies spp. (fir)

A. fraseri (Fraser fir), cellulase activity as a mechanism for suppression of Phytophthora root rot in, 223

A. grandis (grand fir), current season needle necrosis in, S31

A. nordmanniana (Nordmann fir), current season needle necrosis in, S31

A. procera (noble fir), current season needle necrosis in, S31

Abou Ghanem-Sabanadzovic, N., S158

Abscisic acid

Cercospora zeae-maydis production of, $\mathrm{S} 44$

potato purple top phytoplasma on tomato and, S275

Abu-El Samen, F. M., S2

Acacia spp.

A. koa (koa trees)

Fusarium oxysporum on, S165, S216 species profile and genetic variation in

Fusarium spp. isolated from, S146

A. mangium, root rot disease of, fungal antagonists for, $\mathrm{S} 114$

Acalypha wilkesiana (acalifa), Golovinomyces sp. on, $\mathrm{S} 253$

Acaricides, fenpropathrin, for Panonychus citri on

citrus, S186

Aceria tosichella (wheat curl mite)

Triticum mosaic virus in wheat and, S2.6

on wheat, virus transmission by, S71

Acerophagus papayae, for control of Paracoccus

marginatus on papaya, S85

Acetylcholinesterase, purified from field popu-

lations of Bactrocera dorsalis, S186

Acevedo, M., S21, S127

Acevedo-Torres, V., S276

Achata Bottger, J., S2

Achromobactin, synthesis of by Pseudomonas

syringae pv. syringae, iron responsive sigma factor and, S64

Acidovorax spp.

A. avenae

on cucurbits, S196

on millet, $\mathrm{S} 198$

on sugarcane, $\mathrm{S} 64$

A. cattleyae, on Phalaenopsis spp., S175

A. citrulli, on watermelon, S182, S265

Acosta-Leal, R., S194, 416

Actigard, for Xanthomonas perforans on tomato, S269

Actinomycetes, isolated from herbal vermicomposts, biocontrol and plant growth promotion potential of, $\mathrm{S} 62$

Adaskaveg, J., S2, S54, S111, S118

Adaskaveg, J. E., 1013

Adati, T., S224

Addy, H. S., S2

Adekunle, A. A., S131
Adesemoye, A., S2, S49

Adesemoye, A. O., S244

Adhikari, T., S127, S168, S243

Adhikari, T. B., 687, 1251, 1301, S2.7

Adjuvants, haloxyfop-methyl application and, S8

Adkins, S., S189

Adkins, S. W., S238

Aegilops longissima, Oculimacula spp. on, S165

Afla-Guard, for management of aflatoxin contamination in corn, S40

Aflatoxin

advances in management of in Africa, S225

Aspergillus flavus and

on almond, S44

on common bean, $\mathrm{S} 23$

on corn: detection of aflatoxin-producing isolates, S193; gene expression profile and response to kernels, 797; genetic diversity within vegetative compatibility group of, S250; in Mexico, S181; in Oklahoma, S40

in corn, reduction of by biocontrol strains of Aspergillus flavus, $\mathrm{S} 1$

preventing aflatoxicosis outbreaks in Kenya and, S222

proteins associated with resistance against in corn, S21

ribosomal intergenic spacer analysis, soil fungal community structure in peanut and, 52 risk assessment of contamination in peanut, S222

African citrus psyllid. See Trioza erytreae

African rice gall midge. See Orseolia oryzivora

Afunian, M., S87

Agaricus bisporus, Pseudomonas tolaasii on, essential oils for control of, S7

Agent-based modeling, of plant virus-host-vector interactions, S67

Aggarwal, R., S230

Aghamohammadi, V., S3

Agrobacterium spp.

A. tumefaciens

$\mathrm{T}$-complex recruiting protein $\mathrm{VBP}$ in, $\mathrm{S} 58$ for transformation of sugarcane, S122 on walnut, S91, S196

A. vitis

on grape, $\mathrm{S} 23, \mathrm{~S} 86$

on tobacco, $\mathrm{S} 23$

Agrostis palustris. See Agrostis stolonifera

Agrostis stolonifera (creeping bentgrass)

bacteria associated with disease syndrome of, S54

DMI fungicide applications and, S165

Rhizoctonia solani on, fungicides for control of, S41

Waitea circinata on, S35

Agudelo, P., S214

Aguilar-Pérez, L. A., S3, S98, S128

Ahangaran, A., S122

Ahmed, H. U., S77

Ah-You, N., 887

Aihuan, Z., S84

Ailanthus altissima (tree-of-heaven), Verticillium

albo-atrum on, $\mathrm{S} 89$

Aime, M. C., S157, S216

Ajlan, A. M., S3

Akagi, A., 1311

Akahoshi, K., S3

Akamatsu, H., S135

Akami, A., S3

Akridge, R., S68

Akula, N., S4

Al Rwahnih, M., S4, S61, S134

Al Shudifat, A. M., S2

Alabi, O. J., S4, S143, S144, 1446
Alagely, A., S176

Alananbeh, K., S115, S241

Alananbeh, K. M., S4, S241, S2.1

Alarcon, P. A., S71

Alborn, H. T., S214

Albrecht, A., S112

Albrecht, A. S., S249

Albrecht, K. D., S178

Albrigo, G., S178

Alcala, A. C., S4

Aldana, R., S254, S255

Aldicarb, root-knot nematode and Fusarium wilt

disease complex in cotton and, S270

Aldrich-Wolfe, L., S5

Alemow. See Citrus macrophylla

Aleurocanthus woglumi (citrus black fly), on citrus in Brazil, S27, S28, S29

Aleurodicus dispersus, geminiviruses in pepper and, S150

Alfalfa. See Medicago sativa

Alfano, J. R., S231

Alfenas, A. C., S127, S215, 555, 1005

Alfenas-Zerbini, P., S104

Alff, E., S5

Alford, S., S239

Algicides, for Phytophthora spp. in infested water, S119

Algu gene, Xylella fastidiosa and, S165

Alhudaib, K., S5

Alhudaib, K. A., S3

Ali, S., S5

Alicandro, J., S80

Alkaloids, for control of Clavibacter michiganen-

sis subsp. michiganensis on tomato, $\mathrm{S} 101$

Alkharouf, N. W., S209

Allen, C., S80, S121

Allen, F. L., S174

Allen, R., S155

Allen, T., S5

Allen, T. W., S85, 1122

Alligatorweed. See Alternanthera philoxeroides

Allium spp.

A. cepa (onion)

Alternaria porri on, management with bioformulations and fungicides, S42

bio-fumigation and soil solarization and, S143

Burkholderia cepacia on, S189

integrated pest management and, S56

Iris yellow spot virus in, S17, S109, S164, S172

management of bacterial diseases using mulches and plant spacing, S65

Pantoea ananatis on, S274

real-time disease/pest monitoring and reporting network for, S161

Sclerotium cepivorum on, novel fungicides for control of, S52

Thrips tabaci on, resistance against, $\mathrm{S} 17$

A. sativum (garlic)

Pseudomonas marginalis on, S115

Sclerotium cepivorum on, S179

Allokermes sp., on oak, S168

Almeida, R. P. P., 445

Almeyda, C. V., S5

Almond. See Prunus dulcis

Alpas, H., S65

ALS (acetohydroxyacid/acetolactate synthase) inhibiting herbicides, current state of resistance to, S236

Al-Taweel, K., S52

Altenbach, D., S6

Alternanthera mosaic virus (AltMV), in clock vine, S182

Alternanthera philoxeroides (alligatorweed), 
Nimbya alternantherae on, S194

Alternaria spp.

on almond, natural fungicide resistance and, S54

A. alternata

on citrus, S171, S182

on nut trees, fungicide resistance and, S166 on potato, $\mathrm{S} 180$

A. brassicicola

Amr1, melanin biosynthesis, and conidium production in, S36

on cabbage, $\mathrm{S} 171$

on cauliflower, S164

for control of Cephalanoplos setosum, S68

A. mali on apple, $\mathrm{S} 155$

A. porri, on onion, $\mathrm{S} 42$

A. radicina, on carrot, $\mathrm{S} 178$

A. solani

on potato, S60, S180, S190

on tomato, $\mathrm{S} 2$

A. tenuissima, heat-stable elicitor protein from, $\mathrm{S} 148$

A. tomatophila, on black nightshade, S74

Altier, N. A., S140

Alvarado-Rodríguez, M., S54

Alvarez, A. M., S114, S161

Alvarez, E., S6, S253

Alves, F. R., S82

Alwang, J., S227

Amaranthus spp.

Microsphaeropsis amaranthi and Phomopsis amaranthicola for control of, S134

Thecaphora amaranthi on, S123

Amazon forest species, diversity of plant pathogenic fungi associated with, S166

Ambrose, G., 323

Ambrosia beetle. See Xyleborus sp.

Ambrosia spp. (ragweed)

ability of native insects of Hungary to suppress, S238

biological control of, S185

weed management and human allergy and, S237

as worldwide problem, S93

Ambylseius barkeri, effect of temperature on development of, S107

Ameen, G., S2.1

Amemiya, Y., S6

Ames, K. A., S189, S246, S2.3, S2.8

AMF. See Arbuscular mycorrhizal fungi

Aminaee, M., S13

L-Amino acid oxidase isolated from, from Tricho-

derma harzianum, S108, S251

Amiri, A., S241

Amiri, S., 945

Ammar, E., S6

Amos, O., S6

Amphorophora agathonica, Raspberry latent virus transmission and, S149

Amr1 transcription factor, Alternaria brassicicola infection and, S36

AMV. See Apple mosaic virus

Amylovoran

Erwinia amylovora, EnvZ/OmpR and GrrS/

GrrA systems and, S102

RcsC sensor kinase of Erwinia amylovora and 710

Amyotte, S. G., S208

Anagyrus loeckii, for control of Paracoccus marginatus on papaya, S85

Ananas comosus (pineapple)

closteroviruses infecting, S42, S229

Phytophthora nicotianae on, S167

Anchieta, A., S208

Anco, D. J., S221

Andaloro, J. T., S235

Anders, M., S7

Andersen, P., S279

Andersen, P. C., S170
Anderson, B. L., S199

Anderson, R., S230

Andreason, S., S7

Andreeva, K., S7

Angel, C. A., S7

Anikster, Y., 870

Anisogramma anomala, on hazelnut

ascospore viability and dispersal from pruned branches, S71

detection of in breeding programs, S123

genome sequencing and analysis of, S25

Anna Maria, V., S7

Annual bluegrass. See Poa spp.

Ansari Dezfooli, N., S7

Antagonist yeasts

cloning glucanase and chitinase from, S66

for control of Salmonella enterica on lettuce, S66

Anthocyanins, grapevine leafroll disease and, S67

Anthracnose. See Colletotrichum spp.; Elsinoe ampelina

Anthurium andraeanum

Radopholus similis on, innate response in tissue cultures, S113

Antibiosis, Pseudomonas spp. for control of

Clavibacter michiganensis on tomato and, S98

Antibiotics, phenazine-1-carboxylic acid, Strepto-

myces scabies on potato and, S9

Anticarsia gemmatalis (velvet bean caterpillar),

biological control of, $\mathrm{S} 224$

Antignani, V., S230

Antimicrobial peptides, TMV-based transient

expression system for, S163

Antuniassi, U. R., S8

Aphids

Banana bunchy top virus and, localization of within aphid vector, S20

Beet yellows virus transmission and, S230

Carrot thin leaf virus transmission and, S194

Cucurbit aphid-borne yellows virus and, protein-protein interaction of, S32

identification of common fungi infecting, S153

mulches for management of, S130

multiplex RT-PCR for detection of mixed

infections viral infections and, S163

Peronospora belbahrii on basil and, S263

on ragweed in Hungary, S238

Raspberry latent virus transmission and, S149

Soybean mosaic virus and, S274

sweet potato potyviruses and, S270

on wheat, arbuscular mycorrhizae and, S2

Aphis fabae, on ragweed in Hungary, S238

Aphis glycines, identification of common fungi infecting, S153

Aphthona spp., for control of Euphorbia esula/ virgata, $\mathrm{S} 24$

Appel, D., S95

Appharknessia sp., for control of pathogens of

Brassica rapa, $\mathrm{S} 37$

Apple. See Malus spp.

Apple chlorotic leafspot virus, in Prunus spp. in

National Clonal Germplasm Repository, S134

Apple mosaic virus (AMV), in rose, $\mathrm{S} 62$

Apricot. See Prunus spp.

Ara, J., S8, S47, S173

Arabidopsis thaliana

assessment of resistance pathways induced in by Rhizoctonia spp., 828

Bacillus cereus AR156 and resistance in, S129

CRT1 gene family and pathogen immunity in $\mathrm{S} 113$

Fusarium oxysporum on, volatile-mediated plant growth promotion and, S16

hypersensitive response (HR) in, C-terminal region of plant ferredoxin-like protein and, 741

induction of resistance in by hypovirulent Rhizoctonia spp. isolates, S168

iturin and systemic resistance induction, S95 as model host for Xylella fastidiosa, S155

Pseudomonas syringae pv. tomato on, NDR1

integrin-like protein and, S2.5

Arabis mosaic virus (ArMV), in grapevine and rose, $\mathrm{S} 44$

Arachis glabrata, Phytophthora cinnamomi on avocado and, S278

Arachis hypogaea (peanut)

Aspergillus niger on

endophytic associations and mycotoxin production, S135

plant growth promoting rhizobacteria for control of, S200

Cylandrocladium spp. on, prothioconazole for management of, S19

exploring soil bacterial communities in different cropping sequences using multiple molecular approaches, 819

genetic linkage map for whole genome sequence assembly, S66

Peanut Rx for management of diseases of, S56 preventing aflatoxicosis outbreaks in Kenya and, S222

pythium pod rot of, S265

ribosomal intergenic spacer analysis in relation to aflatoxin-producing fungi for comparison of soil fungal community structure, 52

risk assessment of aflatoxin contamination of, S222

Sclerotinia spp. on

S. minor: effect of post-inoculation relative humidity on, S20; ICRISAT mini-core peanut germplasm characterization and, S30; management in Texas, S193; oxalate oxidase gene and resistance, 786; population structure and genetic diversity, S59

S. sclerotiorum, screening core collection for resistance, $\mathrm{S} 168$

Sclerotium rolfsii on

differential gene expression during early interactions between, $\mathrm{S} 84$

rapid laboratory screening method for, S264

Tomato spotted wilt virus in

in North Carolina and Virginia, 147

production practices, cultivar selection, and incidence of disease and yield of, S68

Tomato yellow fruit ring virus in, S62

viruses detected in North Dakota nursery plots, S2.5

Aradhaya, M. K., S92

Aram, K., S8

Arancon, N. Q., S124

Arango, M., S253, S255

Arbuscular mycorrhizal fungi (AMF)

and aphids on wheat, S2

in cheatgrass and big sagebrush communities, S23

Arce-Johnson, P., S163, S250

Arcibal, S. S., S9

Arias, C. R., 52, 819

Arie, T., S233

Arif, M., S2, S9, S135

Ariss, J. J., S176

Aritua, V., S80

Ariza, J., S254

Armengol, J., S83

Armillaria spp.

A. astoyae, on Prunus spp., $\mathrm{S} 188$

A. mellea, clonal and sexual dispersal in ornamental landscape, S178

on peach, high planing, root collar excavation and, S161

in Pinus and Tsuga-dominated forests, S258

A. solidipes

on forest trees, invasiveness of, S91

Armstrong, C., S205

Armstrong, J., S157 
Armstrong, K. F., S70

Armyworm. See Spodoptera spp.

Aromascan electronic-nose instruments, for detec-

tion of termites in wood, S192

Arpaci, B. B., S24

Arredondo, F. D., S230

Arrested ear development, foliar-applied pesti-

cides and surfactants and, S2.8

Arsenault-Labrecque, G., S183, S257

Arseneault, T., S9

Arteaga, H., S10

Artemisia tridentata (big sagebrush), arbuscular mycorrhizal fungi and, S23

Arun, B. M., 367

Arunan, G., S10

Asaad, S., S10

Asafoetida, for management of root diseases of

watermelon and eggplant, S47

Asaro, C., S74

Ascochyta spp.

on chickpea, detection of fungicide resistance and, S62

heterothallism in, $\mathrm{S} 2.2$

Ascophyllum nodosum, extract of for control of thrips on peppers, cucumbers, and Hass avocadoes, S126

Ascospore germination, of Monosporascus can-

nonballus, Olpidium bornovanus-mediated, 794

Ashley, R., S2.6

Ashley-Koch, A., S222

ASI-261, as alternative to methyl bromide, S156

Asian citrus psyllid. See Diaphorina citri

Asian corn borer. See Ostriniae furnacalis

Asian soybean rust (ASR). See Phakopsora pachyrhizi

Askew, A., S221

Askew, S. D., S144

ASM (acibenzolar-S-methyl), for control of Iris yellow spot virus, $\mathrm{S} 178$

Asparagus officinalis, Fusarium spp. on, S258 Aspergillus spp.

A. carbonarius, on grape, novel fruiting structure produced by, $\mathrm{S} 142$

on corn, proteins associated with aflatoxin resistance in, $\mathrm{S} 21$

Flavi section, on almond, aflatoxin producing potential and community structure of, S44

A. flavus

on bean, aflatoxin production and, S23

biocontrol of aflatoxins, cyclopiazonic acid, and fumonisins in corn and, $\mathrm{S}$ community structure and persistence of toxigenic strain AF36, S80

comparison of soil and corn kernel populations, 952

on corn: detection and identification of using solid-phase microextraction, S269 detection of aflatoxin-producing isolates, S193; evaluating resistance using stem inoculations, S193; gene expression profile and response to kernels, 797; genetic diversity within vegetative compatibility group of, S250; management of aflatoxin contamination, S40; in Mexico, aflatoxin contamination and, S181; at varying elevations in Mexico, S133

A. fumigatus, for control of Sclerotinia sclero-

tiorum on soybean, S2.4

A. niger

on corn, endophytic associations and mycotoxin production, $\mathrm{S} 135$

on grape, novel fruiting structure produced by, $\mathrm{S} 142$

nematicidal activity of component from broth filtrate of, S148

nontoxigenic strains, fumonisin biosynthetic genes in, S136

on peanut: endophytic associations and mycotoxin production, S135; plant growth promoting rhizobacteria for control of
S200

A. ochraceus, ochratoxin A biosynthesis in, S48

Asperisporium caricae, on papaya, climate change and, S82

Asselin, J. E., 935

Assunção, I. P., S166

Astragalus sinicus (milk vetch), Pseudomonas viridiflava on, $\mathrm{S} 90$

Astragalus spp. (locoweeds)

Embellisia astragali on, S102

Undifilum spp. on

comparison of Undifilum DNA and swainsonine content, $\mathrm{S} 2$

detection and localization of, S152

new swainsonine-producing species, S14 proteomic analysis of, $\mathrm{S} 104$

Atallah, Z., S208

Atallah, Z. K., S10

Atallah, Z. N., S157

ATG8 autophagy gene, of Verticillium spp., S251

Athinuwat, D., S10

Atiri, G., S78, S158

Atmospheric conditions, exponential and power-

law contact distributions, modeling epidemics and, 1465

Attanayake, R. N., S10

Atumurirava, F., S219

Aubertot, J., S223

Augusto, J., S264

Aun, C. P., S127

Avanzato, M. V., S11

Avenot, H. F., S11

Avila, L. L., S11

Avocado. See Persea americana

Avr genes

of Phytophthora sojae, S190

Phytophthora sojae on soybean and, S246

AVRDC- The World Vegetable Center, overview of, S225

AWR effector proteins, Ralstonia solanacearum virulence and, S168

Aya, H., S254

Aye, S., S11

Azarmanesh, N., S11

Azevedo, J., S96

Aziz, A., 768

Azoxystrobin

for Alternaria solani on tomato, S2

for Asochyta rabiei on chickpea, detection of resistance, $\mathrm{S} 62$

for Cercospora sojana on soybean, resistance to, $\mathrm{S} 132$

for Cercospora zeae-maydis on corn, S31

for Rhizoctonia solani on sugar beet, S89, $\mathrm{S} 126, \mathrm{~S} 245$

Babadoost, M., S12, S94, S259

Babette, G., S247

Baccari, C., 77

Baccari, G. V., S89

Bacillus spp.

B. amyloliquefaciens

and Botrytis cinerea on grape, S71

for control of Fusarium spp. on wheat, S39, S200

B. cereus

for Botrytis cinerea on Formosa lily, induction of systemic disease resistance and plant growth and, S76

strain AR156, resistance in Arabidopsis thaliana and tomato and, S129

for control of Burkholderia glumae on rice, S270

for control of coffee berry borer, S278

for control of Streptomyces spp. on potato, S119

B. firmus

for control of Meloidogyne incognita, 92

strain GB-126, for control of reniform nematode on cotton, S29 iturin production by, systemic acquired resistance in Arabidopsis thaliana and, S95

B. mojavensis, for control of Fusarium verticillioides on corn, $\mathrm{S} 12$

B. sereus, lily systemic resistance and, S248

B. subtilis

amplification culture of endospore formulation of, S76

for control of Xanthomonas citri pv. citri, S202

for Monilinia fructicola, antifungal protein of a newly isolated strain, S204

for Monilinia spp. on peach, S97

for Phytophthora spp. on pepper, S74

for potato disease management, S30

for powdery mildew on cucumber, S111 strain QST713, S184

B. thuringiensis $(\mathrm{Bt})$

Bombyx mori gut bacteria and, S103

for control of Hypantria cunea, S177

in transgenic crops for pest management, impact of on environment and food safety, S226

use of in Brazil, S224

B. vallismortis, for enhancement of plant growth, plant growth and defense activation, S234

Backhouse, D., S12

Backman, P. A., S39, S258

Backus, E. A., 912

Bacon, C., S135

Bacon, C. W., S12, S206

Bacteriophages

for control of Ralstonia solanacearum, S145

for control of Xanthomonas arboricola pv. pruni on peach, S261

Bactrocera spp.

B. dorsalis acetylcholinesterase purified from field populations of, S186

gut bacterial communities in, S185

$B$. invadens, on mango, $\mathrm{S} 182$

B. musae, on banana, $\mathrm{S} 220$

Badebo, A., S132

Badillo-Vargas, I. E., S12

Badji, K., S182

Bae, S., S198

Baeg, J., S36

Baek, E., S199

Baek, I., S100

Bag, S., S12, S121

Bagi, F., S22

Bai, G., 1322

Bailey, B., S112

Bailey, B. A., S272, S274

Baillieul, F., 768

Baird, R., S193

Baird, R. E., S158, S269

Baird, S. M., S33

Bais, H., S5

Bais, H. P., S97

Bait trapping

for Bactrocera invadens on mango, S182

for Erysiphe necator on grape, S139

for Phytophthora ramorum in Italian forests, $\mathrm{S} 182$

Bakanae disease. See Gibberella fujikuroi

Baker, C. A., S183

Bakkeren, G., S208

Bala, K., S247

Balaji, V., 349

Balázs, E., S126

Balbyshev, N., S115

Baldauf, P. M., S22

Baldwin, T. T., S206

Baley, G., S93

Balidion, J. F., S182

Baloch, G. N., S8, S47, S173

Bamboo, USDA-APHIS quarantine program for, $\mathrm{S} 114$ 
Banana. See Musa spp.

Banana bunchy top virus (BBTV)

in banana, cloning and sequence analysis of, S199

localization of within aphid vector, S20

Bancal, R., 1346

Bandyopadhyay, R., S225

Banihashemi, Z., S81

Banik, M., S86

Banks, C., S158

Banno, S., S13, S56

Bao, X., S13

Baptista, L., S277

Barak, J., S212

Barak, J. D., S96

Barash, I., S136

Barba, P., 502

Barbara, D. J., S208

Barbison, L., S20

Barbosa, A. A., S114

Barbosa, J. C., S110

Barboza, N., S151

Barcoding, for identification of quarantine nematodes and close relatives, $\mathrm{S} 90$

Bargeron, C. T., S96

Barley. See Hordeum vulgare

Barnes, J., S51, S172, S184

Barnham, J., S267

Barouti, S., S175

Barphagha, I., S264

Barphagha, I. K., S88, S266

Barreau, C., 929

Barros, D. R., S104

Barros, V. D., S174

Barsam, S., S13

Barton, W. R., S115

Bartz, J. A., S13

Basi, S., S13

Basil. See Ocimum basilicum

Basky, Z., S238

Basra, S. A., S151

Bata, H., S242

Bates, A. A., S77

Bates, C., S59

Batuman, O., S13

Batzer, J. C., S2.6

Bau, H., S35

Baucom, D., S14, S102

Baudoin, A., S274

Baughman, T., S193

Baumgartner, K., S14, S56, S156, S178

Bay laurel. See Laurus nobilis

Bayesian statistical methods

and framework for analysis of risk factors for crop health under global change and agricultural shifts, 696

for investigating the genetic structure of Phytophthora capsici populations, 1061

for loss caused by Tomato spotted wilt virus on tobacco in winter weather, 462

in meta-analysis, 42

Baysal-Gurel, F., S14, S101

BBTV. See Banana bunchy top virus

BBWV2. See Broad bean wilt virus 2

BCTV. See Beet curly top virus

BDMV. See Bean dwarf mosaic virus

Bean. See Phaseolus spp.

Bean bug. See Riptortus pedestris

Bean dwarf mosaic virus (BDMV), tobacco Hspalpha protein and movement of, S137

Bean leaf beetles, Bean pod mottle virus and, S274

Bean leafroll virus (BLRV)

in alfalfa, $\mathrm{S} 182$

in pea, $\mathrm{S} 2.5$

Bean pod mottle virus (BPMV)

bean leaf beetles and, S274

in soybean in Nigeria, S78

Beaulieu, C., 1045

Beauveria bassiana cultivation of endophytic strain, S80

on mulberry, silkworm white muscardine and, $\mathrm{S} 224$

Rhizoctonia and Pythium spp. spore germination and, S109

Beaver, J., S277, S278

Becerra, V. C., S120

Becker, J. O., S197

Beckerman, J., S14, S242, S2.3

Beckerman, J. L., S213, S244, S2.5

Beech. See Fagus sylvatica

Beer, S. V., 935

Beet. See Beta vulgaris

Beet Curly Top Virus (BCTV), quantification and differentiation in mixed viral infections, S139

Beet cyst nematode. See Heterodera schachtii

Beet mild curly top virus (BMCTV)

effect of host plants on single and mixed infections, S192

quantification and differentiation in mixed viral infections, S139

Beet necrotic yellow vein virus (BNYVV), resistance-breaking ability of, 718

Beet pseudo yellows virus, in cucurbits in Costa

Rica, S151

Beet severe curly top virus (BSCTV)

effect of host plants on single and mixed infections, S192

quantification and differentiation in mixed viral infections, S139

Beet webworm moth. See Loxostege sticticalis

Beet yellows virus (BYV), aphid transmission of, S230

Begley, T. P., S64

Begomoviruses

genetic diversity, geographic distribution of in Yunnan, China, S43

infectivity in Nicotiana benthamiana, S277

in leguminous weeds, Macrophilum lathyroides and, $\mathrm{S} 166$

whiteflies and, in pepper and tomato, S210

Behn, J. L., S2.1

Beirn, L. A., S14, S211

Beitler, J., S232

Bekkaoui, D., S67

Bekoscke, K., S14

Bélanger, R. R., S183, S257, S260

Belcher, A. R., S15, S190

Belfon, R., S14

Belgeri Garcia, A., S238

Beligan, G., S170

Belisario, A., 679

Bell, A. A., S119

Bell pepper. See Capsicum annuит

Bellomo, L. M., 182

Belzile, F., S183

Bemisia tabaci (whitefly)

Begomovirus spp. and, in pepper and tomato, S210

biotype Q on field crops in China, S201

cassava mosaic disease and, S210

criniviruses in multiple crops in Costa Rica and, S151

geminiviruses in pepper and, S150

Leaf curl virus transmission by, eco-friendly management methods, $\mathrm{S} 96$

parasitoids of, $\mathrm{S} 185$

PCR primers for rapid identification of, S7

resistance traits from wild tomato and feeding behavior of, Tomato yellow leaf curl virus spread and, 1191

on sweet potato, $\mathrm{S} 201$

Ben M'Barek, S., S208

Benimadhu, S. P., S109

Benitez, M., S133, S183

Benson, D. M., S110, 223, 1373

Bentgrass. See Agrostis stolonifera

Benzimidazoles, resistance of Botrytis cinerea against, S56

Berbegal, M., S83
Berendsen, S., S133

Berg, R., S150

Bergdahl, D. R., S257

Bergdahl, J. A., S257

Bergstrom, G., S39

Bergstrom, G. C., 594

Bermudagrass. See Cynodon dactylon

Bernal, A., S120

Bernal, A. J., S152, S179

Bernal Giraldo, A. J., S152

Bernards, M. L., S2.9

Berner, D. K., S258, S272

Bernhardt, E., S8

Bernier, L., S262

Berríos, J., S162

Berrios, L., S253

Berry, S., S66

Bertin, A., S65

Bestor, N., S242, S2.1

Bestor, N. R., S15

Beta vulgaris (beet)

Beet necrotic yellow vein virus in, resistancebreaking ability of, 718

Cercospora beticola on, integrated disease management for, $\mathrm{S} 22$

Fusarium spp. isolated from, on wheat, 1338

Fusarium spp. on, 1330, S2.5

Leuconostoc mesenteroides on, storability and, $\mathrm{S} 172$

Loxostege sticticalis on, S202

Rhizoctonia solani on

aggressiveness and crop rotation, $\mathrm{S} 19$

azoxystrobin for, S89, S245

depth at which causes infection, S246

genetic characterization of population isolated from, S159

metconazole for, $\mathrm{S} 118$

negative interactions between glyphosate and azoxystrobin and, S126

remote sensing for detection of, S153

storability and, S172

Bettiga, L. J., S139

Beukes, I., S18

Bhanare, K., S61

Bharti, A., S208

Bhat, R. G., S15, S160

Bhatnagar, D., S21

Bhattarai, M., S225

Bi, Y., 1104

Bibi, F., S15

Biddle, E., S206

Bill and Melinda Gates Foundation, seed supply challenges in sub Saharan Africa and, S232

Binary power law, heterogeneity of disease incidence and, 1396

Biochar, use of to increase mycorrhizal colonization and suppress Fusarium crown rot of asparagus, S258

Biocides, forest products protection and, S197

Biodiversity, soil, effect of on fungistasis, disease suppression, and colonization by biological control agents, S160

Biofilms

formation of by Xanthomonas citri ssp. citri, S101

Xylella fastidiosa on grape and, S141

Bioindicators, Psyllobora vigintimaculata, for Erysiphe necator, S139

Bioinformatics, for study of type III effector signals, S145

Biological control

of Aleurocanthus woglumi on citrus in Brazil, S27, S28

of Alternaria porri on onion, S42

of Anticarsia gemmatalis, in Brazil, S224

of arthropod pests in Indonesia, S224

of Aspergillus niger on peanut, S200

Bacillus thuringiensis (Bt) cry genes in transgenic crops, S226

bioprotection strategy for greater integration 
of beneficial microbes into IPM, S223

of Botrytis cinerea, on geraniums, S2.4

in Brazil, S224

of Cephalanoplos setosum, S68

of diamondback moth on collard greens, S53

of early blight and septoria leaf spot in tomato,

S51

of Erwinia amylovora, on pear, 113, 299

of Fusarium oxysporum sp. cubense on

banana, $\mathrm{S} 89$

genes, metabolites, and regulatory pathways of

bacteria involved in, S231

of Gibberella zeae on wheat, S200

of Helicoverpa spp., S224

of invasive pests and diseases in the Pacific,

S219

of leaf curl diseases, $\mathrm{S} 96$

of major pests in African cropping systems, $\mathrm{S} 224$

of Meloidogyne incognita, 92

of Monilinia spp. on peach, S97

of Paracoccus marginatus on papaya, S85

pasture bioprotection and, S224

of Phytophthora cinnamomi on avocado, S278

of powdery mildew

on cucumber, S111

on dogwood, S112

review of effectiveness of, S213

of Salmonella enterica on lettuce, S66

of Sclerotinia spp.

on lettuce, 358

on soybean, $\mathrm{S} 2.4$

of silvery threadmoss, in golf course greens

and nurseries, S144

of Xanthomonas campestris pv. vesicatoria on pepper, S154

of Xanthomonas citri pv. citri, S202

of Xylella fastidiosa, using endophytic bacteria, S96

Biological control agents

actinomycetes isolated from herbal vermicomposts as, S62

Actinovate, for Fusarium oxysporum f. sp. niveum on watermelon, S72

Agrobacterium vitis strain F25 (nontumerigenic) for control of A. vitis on grape, S86

as alternatives to chemical fumigants, S233

analysis of products evaluated for control of fire blight, 512

antagonist yeasts, S66

Appharknessia sp., for control of pathogens of

Brassica rapa, $\mathrm{S} 37$

asafoetida, for management of root diseases of

watermelon and eggplant, S47

Aspergillus spp.

A. flavus: for aflatoxins, cyclopiazonic acid, and fumonisins in corn, $\mathrm{S} 1$; for management of aflatoxin contamination in corn, $\mathrm{S} 40$

A. fumigatus, for control of Sclerotinia sclerotiorum on soybean, S2.4

Bacillus spp.

B. amyloliquefaciens: for Botrytis cinerea on grape, S71; for control of Fusarium spp. on wheat, S200; for Fusarium graminearum on wheat, S39

B. cereus: for Botrytis cinerea on Formosa lily, S76; strain AR156, S129

for control of Burkholderia glumae on rice, S270

for control of coffee berry borer, S278

B. firmus: for Heterodera glycines on soybean, S161; for Meloidogyne incognita, 92; strain GB-126, for control of reniform nematode on cotton, S29

B. mojavensis, for control of Fusarium verticillioides on corn, $\mathrm{S} 12$

$B$. sereus, lily systemic resistance and, S248

for Streptomyces spp. on potato, S119
B. subtilis: amplification culture of endospore formulation, S76; for Aspergillus niger on peanut, S200; for control of Xanthomonas citri pv. citri, S202; for Monilinia fructicola, S204; for Phytophthora spp. on pepper, S74; for potato disease management, S30; for powdery mildew on cucumber, S111; for Rhizoctonia solani on rice, S204; for Xanthomonas axonopodis pv. citri on citrus, S76

B. thuringiensis (Bt): Bombyx mori gut bacteria and, S103; in Brazil, S224; for control of Hypantria cunea, S177

B. vallismortis, for enhancement of plant growth, plant growth and defense activation, S234

bacteriophages

for Ralstonia solanacearum, S145

for Xanthomonas arboricola pv. pruni on peach, S261

Beauveria bassiana

cultivation of endophytic strain, S80

silkworm white muscardine and, S224

BlightBan A506, for Erwinia amylovora on pear, 113, 299

Brassica juncea, for Phytophthora nicotianae on tobacco, $\mathrm{S} 73$

Burkholderia contaminans strain MS14, occF gene associated with occidiofungin production in, S33

Candida intermedia, for Botrytis cinerea on strawberry, 859

Chromobacterium sensu lato, for Phytophthora cinnamomi on cranberry, S168

Chromobacterium spp., chromomycin from, $\mathrm{S} 231$

Chromolaena odorata extract, for Rhizoctonia solani, on rice, 231

combined use of

in theory and practice, 1024

using two agents with different mechanisms in controlling foliar pathogens, 1032

compost water extracts, against anthracnoses of pepper and cucumber, 732

composts, control of plant pathogens by microorganisms isolated from, S66

Coniothyrium minitans

for control of Sclerotinia sclerotiorum on soybean, S126, S245, S2.4

new strain from Iowa, S2.4

for Sclerotinia spp. on lettuce, 358

Cryptococcus flavescens, for Fusarium spp. on wheat, S160, S200

cymene, Rhizoctonia and Pythium spp. spore germination and, S109

Ectropis oblique nucleopolyhedrovirus

(EoNPV), for control of tea looper, S194

effect of microbial diversity on, S160

Epiblema strenuana and Ophraella communa, for control of ragweed, S185

epiphytic yeasts, for Botrytis cinerea on grape, S162

for Erwinia amylovora under field conditions, S60

essential oils

against brown blotch disease on Agaricus bisporus, $\mathrm{S} 7$

for control of pinewood nematode, S137

fish emulsion, for potato scab management and potato yield enhancement, S1

Fusarium oxysporum (nonpathogenic), on cucumber, control of Fusarium wilt disease and, S37

Ganoderma lucidum, for control of Xanthomonas campestris pv. vesicatoria on pepper, $\mathrm{S} 154$

Gliocladium spp., for control of root rot disease of Acacia mangium, $\mathrm{S} 114$

Glucoraphane, Rhizopus stolonifer on strawberry and, $\mathrm{S} 128$
Green Muscle, for control of hopper bands of locusts and sahelian grasshoppers, S224

Gymnoascus reessii za-130, extraction of active component from, S107

for Hyparrhenia rufa, S278

Hyptis suaveolens essential oil for control of mosquitoes, S132

isolated from Trichoderma harzianum

L-amino oxidase, S108

evaluation of, S108

iturin, systemic acquired resistance in $\mathrm{Arabi}_{\text {- }}$

dopsis thaliana and, S95

for Japanese knotweed, S179

Laetisaria arvalis, for control of Pyrenophora teres on barley, S98

leaf anthracnose for control of swallow worts, S272

Lysobacter enzymogenes

for Magnaporthe oryzae on rice, S116

pathogenesis as mechanism of biological control by, S231

role of type IV pilus in, $\mathrm{S} 138$

marker-assisted selection for improvement of bioprospecting for, $\mathrm{S} 137$

Martelella endophytica, for Phytophthora capsici and Pythium ultimum, plant growth promotion, resistance induction, nitrogen fixation and, S15

Maruca vitrala Multiple Nucleopolyhedrovirus (MaviMNPV), S224

Metarhizium anisopliae

for control of hopper bands of locusts and sahelian grasshoppers, S224

for sugar cane pests, S224

Microsphaeropsis amaranthi and Phomopsis amaranthicola, for control of waterhemp and redroot pigweed, $\mathrm{S} 134$

Mycosphaerella spp., for control of Japanese knotweed, S56, S95

mycoviruses

for Macrophomina phaseolina, S169 for Sclerotinia sclerotiorum, S83

Myrothecium roridum, for control of water lettuce, $\mathrm{S} 131$

ningnanmycin, for control of Sclerotinia homeocarpa and Colletotrichum cereale, on turfgrass, S111

nucleopolyhedroviruses, S224

for onion, management of bacterial diseases using mulches and plant spacing, S65

Paecilomyces lilacinus, for root-knot nematode, S90, 92

Paenibacillus polymyxa, for Botrytis cinerea on grape, S71

Pantoea spp.

P. agglomerans E325: against Erwinia amylovora on apple flower stigmas, S146, 1234; monitoring environmental impact and behavior in orchards, S19 applied genomics to understand and improve biocontrol activity of, S232

Peak, S77

plant extracts, for Rhizoctonia spp. and Sclerotium hydrophilum on rice, $\mathrm{S} 11$

Pochonia chlamydosporia var. catenulata, for Meloidogyne incognita, 92

for potato, inducible defense genes, metabolic genes and, S30

Pseudomonas spp.

$P$. aureofaciens, for control of Sclerotinia homeocarpa on turfgrasses, S2.9

for Clavibacter michiganensis on tomato, S98

P. CMR12a, for control of Rhizoctonia solani on bean, 996

P. fluorescens: Q2-87 and Q8r1-96, S231; SP007s for control of rice pathogens, S146; on tomato, S116

for Gaeumannomyces graminis var. tritici, S201, 148 
for Helminthosporium solani on potato, S257

LBUM300, monitoring gene expression of in soil, $\mathrm{S} 130$

properties of isolates, $\mathrm{S} 117$

for Ralstonia solanacearum on tobacco, $\mathrm{S} 72$

spontaneous GAC mutants in, S45

for Streptomyces scabies on potato, S9

Pseudozyma flocculosa, Ustilago maydis as model system for study of glycolipid gene cluster in, S260

Puccinia punctiformis, for control of Canada thistle, S39, S258

purified fire ant venom alkaloids, for control of Clavibacter michiganensis subsp. michiganensis on tomato, S101

Pythium spp.

$P$. nunn, for control of $P$. ultimum and $P$. aphanidermatum, $\mathrm{S} 177$

P. oligandrum, for control Esca pathogenic attack, S21

Reynoutria sp., for control of Rhizoctonia solani and Pythium ultimum on soybean and cotton, S172

Rhizobacteria spp., for multiple pathogens on pepper, 666

Rhizoctonia spp.

induction of resistance in Arabidopsis by, $\mathrm{S} 168$

$R$. solani, for potato disease management, S30

for root rots of groundnuts, S164

Scutellaria, for control of Monilinia fructicola on peach, $\mathrm{S} 107$

seaweed

extract of for control of thrips on peppers cucumbers, and Hass avocadoes, S126

for management of root diseases of watermelon and eggplant, S47

for suppression of root diseases of cotton and chili, S8

seed meals, for Macrophomina phaseolina on strawberry, S117

Serratia entomophila, for control of New

Zealand grass grub, S224

Spodoptera exigua nucleopolyhedrovirus, S225

Streptomyces spp.

for control of Phytophthora spp., S180

$S$. lydicus: breeding effective strain of S107; for control of Xanthomonas cam pestris pv. vesicatoria on pepper, S154

Synchytrium solstitiale, for control of yellow

starthistle, S273

Talaromyces trachyspermus, for control of

Sclerotinia sclerotiorum on soybean, S2.4

Trichoderma spp.

T. asperellum, for control of Phytophthora ramorum in nursery soil, S191

for control of Sclerotinia sclerotiorum, on bean, S109

T. harzianum: Botrytis cinerea and, S106; chrysophanol and pachybasin from, S106; interaction with Fusarium solani f. sp. pisi, $\mathrm{S} 91$

heat shock response in, $\mathrm{S} 145$

T. koningi, genes from in Materhizium anisopliae, S33

for root rot disease of Acacia mangium, $\mathrm{S} 114$

T. virens, for potato disease management, S30

Trichogramma dendrolimi, for Asian corn borer, S39

Vericompost tea, for Phytophthora nicotianae on pineapple, $\mathrm{S} 167$

Veronica anthelmintica, for Meloidogyne javonica, $\mathrm{S} 173$

Bionem. See Bacillus firmus

Bioprospecting, marker-assisted selection and
S137

Biosecurity. See also Quarantine

agroecosystem resilience in water limited

wheat-based cropping systems and, S226

EU network of excellence for, S65

global threats and issues of, S216

international perspective on, S216

Biotechnology. See Genetic engineering; Transgenic crops

Bipolaris oryzae

on rice

Chromolaena odorata extract for control of, 231

deficiency in silicon uptake and, 92 on switchgrass, S61

Bird, D. M., S42

Bird, Julio, six decades with, S278

Birdseed, Sclerotinia sclerotiorum in, S2.7

Birithia, R., S172

Birun, L., S15

Bissonnette, K. M., S16

Bitas, K. M., S16

Bitas, V., S16

Bitterlin, W., S6

Black, J., S16

Black nightshade. See Solanum sp.

Black raspberry necrosis virus (BRNV), elimination of by in vitro therapy, S81

Black root rot disease complex, on strawberry, S108, S178

Black shadow disease, on blueberry, S143

Black sigatoka. See Mycosphaerella fijiensis

Black walnut. See Juglans nigra

Blackberry. See Rubus spp.

Blackberry chlorotic ringspot virus (BCRV), epidemiological studies on, S145

Blackberry yellow vein associated virus (BYVaV) elimination of by in vitro therapy, $\mathrm{S} 81$ as emaravirus, $\mathrm{S} 70$

epidemiological studies on, S145, S268 overview of, $\mathrm{S} 229$

Blackeye cowpea mosaic virus (B1CMV), in soy-

bean in Nigeria, S78

Blackstain root disease, of Ponderosa pine, S135

Blades, S., S230

Blagden, T., S16, S81

Blahut-Beatty, L., S25

Blair, J. E., S16

Blanchette, R., S78

Blanchette, R. A., S140

Blanco-Meneses, M., S153

Blast. See Pyricularia oryzae

BlCMV. See Blackeye cowpea mosaic virus

Bledsoe, M. E., S101

BlightBan A506, for control of Erwinia amylovora on pear, 113, 299

Block, C. C., S16

Blom, J., S144

Blood, R. Y., S17

Blough, K., S59

Blueberry. See Vaccinium corymbosum

Blueberry necrotic ring blotch virus (BNRBV), in blueberry, S115

Bluegrasses. See Poa spp

Bluhm, B. H., S44, S72, S113, S153, S167

Blumeria graminis

barley host and nonhost resistances and, S202

on triticale, analysis of interaction between, S53

on wheat

in China, S45

$\mathrm{N}$-deficiency and, S22

Blumeriella japaii, on Prunus spp., S86

Blumer-Schuette, S. E., 182

Blunt, T., S17

BMCTV. See Beet mild curly top virus

BNRBV. See Blueberry necrotic ring blotch virus

BNYVV. See Beet necrotic yellow vein virus

Boateng, C., S17

Bock, C. H., S17, S193, S196
Bockelman, H. E., S127

Bockus, W., S220, S243

Bockus, W. W., S18, S40, S141, 1251, 1322

Bodiroga, D., S109

Boehm, M. J., S160

Boerma, H. R., 535

Bohannon, R., S157

Bohlmann, H., S163

Bohlmann, J., S188

Bois noir, new approach to management of, S156

Boiteux, L. S., S43, S152

Bojanowski, A., S257

Bolaños-C, C., S276

Boland, G., S20

Bolat, N., S226

Bolda, M., 523

Bolton, M., S245, S246

Bolton, M. D., S157

Bombyx mori, gut bacteria of, B. thuringiensis

(Bt) and, $\mathrm{S} 103$

Bonani, J. P., 1191

Bonanomi, G., S160

Bonants, P., S153, S218

Bonants, P. J., S18

Bonasera, J. M., 935

Bond, J., S11, S79, S171

Bond, J. P., S11, S113, S209, S246, S2.3

Bonde, M. R., 894

Bonifert, M., S65

Bonilla, L. L., S253

Bonilla Avilés, L. L., S276

Bonman, J., S127, S2.7

Bonman, J. M., 1301

Bonsall, R. F., 1481

Booker, B., S156

Boonham, N., S46, S53, 1365

Boonkerd, N., S200

Borchert, D. M., S46

Borneman, J., S197

Bornemann, K., 718

Borodynko, N., S18, S70

Borrego, E., S230

Borth, W., S42, S119

Borth, W. B., S229

Borthakur, D., S216

Boscalid

for Botrytis cinerea on apple, resistance to, 986, 1385

for Sclerotinia spp. on lettuce, S249

Boscia, D., 611

Bost, S. C., S121

Bostock, R. M., S78, S147

Botryosphaeria spp.

B. dothidea

on apple, $\mathrm{S} 175$

on blueberry, S194

evaluation of control agents for, S170

on live oak, species complex, S111

live oak mortality and, S248

Botrytis spp.

on blackberry, identification of new, S103

B. cinerea

on apple: boscalid resistance and, 986, 1385; endogenous ethylene biosynthesis and resistance to, 1311; multiple resistance phenotypes of, S90; pyraclostrobin resistance and, 1385

on blackberry, postharvest control of, S151 on Brassica rapa, Appharknessia sp. for control of, S37

fungicide resistance of, S56

on geraniums, S2.4

on grape: characterization of $B s l$ genes in response to, S250; epiphytic yeasts for biocontrol of, S162; fenhexamid resistance and, S158; multidrug resistant, promoter rearrangements and, $1176 ; B$. pseudocinerea and, 1433; R2R3MYB transcription factor and, S163 
on raspberry, S69

resistance against, grapevine-associated bacteria that induce a prime oxidative burst and phytoalexin production and, 768

on solanaceae, molecular and biochemical characterization of resistance, S167

on strawberry: control of by volatile organic compounds of Candida inter media, 859; forecast system for control of, $\mathrm{S} 140$

Trichoderma harzianum and, S106

$B$. pseudocinerea, on grape, B. cinerea and, 1433

Botschner, M., S2.5

Bottle gourd, Didymella bryoniae on, S89

Boudreau, M., S56

Boulais, V. L., S114

Boumin, K., 575

Boutigny, A., S18

Boutigny, A.-L., 929

Bouzidi, M. F., 970

Bowen, C. R., 750

Bowen, K. L., 52, S68, S222, 819

Bowman, H., S106

Bowman, N. D., S110

Boyd, E. C., S151

Boyd, L. A., S220

Boydston, R. A., S144

Boyzo-Marín, J., S151

Brachiaria spp., resistance to Rhizoctonia spp., S6

Brachycaudus helichrysi, on ragweed in Hungary, S238

Bradeen, J. M., S18, S58

Bradley, C., S50, S132, S191, S223

Bradley, C. A., S31, S160, S189, S203, S242,

S246, S267, 1122, S2.3, S2.8, S2.9

Brady, C. R., S19

Brady, J., S18

Bradyrhizobium japonicum, on soybean, norma nodulation, 14-3-3- protein and, S150

Bragard, C., S168, 1149

Branchaud, A., S262

Brandão, R. S., S109

Brandl, M. T., S212

Brankatschk, K., S19

Brannen, P. M., S115

Brantner, J. R., S19

Brasier, C. M., S218

Brassica spp.

B. napus (canola)

Leptosphaeria maculans on: increasing diversity of, S127; population genetic analysis of, S127

Plasmodiophora brassicae on: in Canadian prairies, S179; management of resistant cultivars, S77

Sclerotinia sclerotiorum on: association mapping of resistance against in world collection, S67; genetic diversity and population differentiation, S10; temporal ascospore dispersal pattern during flowering, S147

B. oleracea (broccoli)

Colletotrichum gloeosporioides on, glucoraphane and, S98

Verticillium dahliae on, phenological and phytochemical changes correlating with 523

B. oleracea (cabbage)

Alternaria brassicicola on, S171

Verticillium longisporum and $V$. dahliae on, quantitative detection in soil, $\mathrm{S} 13$

B. oleracea (cauliflower)

Alternaria spp. on, S164

Verticillium dahliae on, phenological and phytochemical changes correlating with, 523

B. oleracea (collard greens), diamondback moth on, biorational insecticides used for, S53
B. rapa subsp. chinensis (pak choy), Plasmodiophora brassicae on, effect of temperature on cortical infection, 1424

for Fusarium oxysporum f. sp. niveum on watermelon and Rhizoctonia solani on rice, S204

for Macrophomina phaesolina on strawberry, S117, S249

Pseudomonas cannabina pv. alisalensis on, S189

for Rhizoctonia solani on apple, S249

as rotation crops, disease suppression in potato and, S98

Braun-Kiewnick, A., S19

Brazee, N. J., S258, S263

Brenneman, T., S19, S264

Brenneman, T. B., S11, S17

Brenneria quercina, on oak, S168

Bressan, A., S20, S24, S72

Breuil, C., S188

Brewer, M. T., S20

Brewster, C., S60

Brewster, C. C., S228

Brinjal, invasive mealybugs on, $\mathrm{S} 162$

Britton, K. O., S20, S137

Brlansky, R., S48

Brlansky, R. H., S36, S156, S199

BRNV. See Black raspberry necrosis virus

Broad bean wilt virus 2 (BBWV2), in pepper, S199

Broccoli. See Brassica oleracea

Brodbeck, B., S279

Brodbeck, B. V., S276

Broders, K., S20

Bromus tectorum (cheatgrass)

arbuscular mycorrhizal fungi and, S23

as invasive weed, S238

Brooks, S., S7

Broome, J. C., S139

Broomrape. See Orobanche spp.

Broscious, S., S184

Brown, A., S21

Brown, C. J., S88, 778

Brown, H., S114

Brown, J., S7, S21, S210

Brown, J. K., S20, S277

Brown, M. J., S20

Brown, R., S21

Brown planthopper. See Nilaparvata lugens

Brown ring patch. See Waitea circinata

Brown root rot. See Phoma sclerotioides

Brown spot. See Bipolaris oryzae

Browne, G. T., S15, S160

Brown-Guedira, G., S127, 1322

Browning, M., S274

Bruckart III, W. L., S273

Brueggeman, R., S21, S64

Bruez, E., S21

Brule-Babel, A., S52

Brunk, G., S17

Bruns, T., S22

Brust, G. E., S22

Bruton, B., S59

BSCTV. See Beet severe curly top virus

BTH (acidbenzolar-S-methyl), for induction of systemic acquired resistance, $\mathrm{S} 233$

Buah, S., S23

Buchman, J. L., S162

Buchwaldt, L., S67

Buck, J., S22, S181

Budakov, D., S22

Buehring, N., S5

Buell, C., S168

Buell, R. C., S247

Buerling, K., S22, S77

Buhrig, W., S15

Bull, C. T., S59, S115, S116, S157, 847

Bulluck, R., S22, S85

Bunderson, T., S129

Bunt. See Tilletia spp.
Burans, J., S16

Burans, J. P., S81

Burbank, L. P., S23

Burdman, S., 436

Burgos, N., S236

Burgos-Garay, M. L., S23, S258

Burkhard cyclone sampler, for air sampling of

three powdery mildew populations, S106

Burkholderia spp.

B. cepacia, on onion, S189

B. contaminans, strain MS14, occF gene associated with occidiofungin production in, S33

B. gladioli, on rice, suppression by pretreatment with various chemicals, S166

B. glumae, on rice

management with beneficial $B$. strains, S270

melanin-like pigments and virulence of, S266

molecular and genomic studies of, S266

NAC-like transcription factor and, S268

PidS/PidR two-component regulatory system of, S88

quorum sensing in, S264

and ratoon, $\mathrm{S} 205$

silver nanoparticles for control of, S36

Burkina Faso, Farmer's Field School approach in, S125

Burlakoti, R. R., 687

Burman, P., 523

Burns, D., S266

Burr, T., S23

Burr, T. J., S10, S27, S37

Burris, E., S266

Bursaphelenchus spp.

B. cocophilus (red ring nematode), on oil palm, S254

B. xylophilus (pinewood nematode) distribution of in stem, xylem embolism development and, S3 on pine, Pseudomonas spp. and, S209 plant essential oils for control of, S137

Buruchara, R. A., S23, S124

Busby, R., S23

Buskila, Y., 436

Butler, D., S156

Butternut. See Juglans cinerea

Buzkan, N., S24

Byamukama, E., S274, S2.2

Byamukama, E. Z., S24

BYV. See Beet yellows virus

Cabanas, D., S24

Cabbage. See Brassica oleracea

Cabos, R., S185

Cabrera-Asencio, I., S255

CABYV. See Cucurbit aphid-borne yellows virus

Cacao. See Theobroma cacao

Cacopsylla picta, spread of Candidatus Phyto-

plasma mali on apple and, 1471

$\mathrm{CaCV}$. See Capsicum chlorosis virus

Cadle-Davidson, L., S14, S158, 502, 839

Cadle-Davidson, M., 502

Caesar, A., S24

Caesar, A. J., S24, S98

Caesar-TonThat, T., S24, S98

Cafaro, M. J., S277

Cafe-Filho, A. C., S97

Caffi, T., S24

Cai, F., S108

Cai, G., S25

Cai, J., S189

Cai, M., 1104

Cai, R., 847

Cai, X. K., 1074

Cain, S., S73

Çakir, B., S65

California bay. See Umbellaria californica

Calla, B., S25, S186 
Calosphaeria pulchella, on sweet cherry, S179

Cambra, M., 611

Camellia spp.

Phytophthora ramorum on, S177

C. sinensis (tea), Pratylenchus loosi on, distribution and population density in Iran, S75

Campa, A., 757

Campbell, F. T., S218

Campbell, J. B., S25

Campbell-Nelson, K., S25, S262

Campell, L., S68

Campoverde, E. V., S26

Canada thistle. See Cirsium arvense

Canaday, C. H., S26

Canary Island date palm. See Phoenix canariensis

CANARY technology, for rapid detection of plant pathogens, S106

Canatharidin, mechanism of toxicity of, S203

Canavirgella banfieldii, on pine, S260

Candida intermedia, volatile organic compounds

of, for control of Botrytis cinerea on strawberry, 859

Candidatus Liberibacter spp.

African citrus psyllid and, S10

Ca. L. asiaticus

analysis of strains for Pakistan, S150

assay to test inoculativity of psyllids with, S6

chemical compounds effective against, 1097 on citrus: orange jasmine plants, and psyllids in Texas, S95; and psyllids in Pakistan, S151; seasonal fluctuation of titers, S110

colonization of citrus seed coats by, 1242

comparison of populations from Brazil, China, and US, S41

detection with high fidelity PCR, S278

in Diaphorina citri, metagenomic analysis using BAC libraries, S205

differentially expressed virulence genes of S170

evaluation of genome for intracellular lifestyle, S70

flagellin protein of, host defense response induced by, S206

genetic diversity of strains from Thailand, S44

hemolysin of, expression in citrus using citrus tristeza virus vector, S68

identification of small molecule inhibitors against SecA of, S4

interactions with nutrients in symptom development and bacterial movement, S84

production of single chain antibodies against, S199

prophages of and their distribution in southern China, S58

on psyllid and citrus hosts in Pakistan, S151

seasonal variation in branches and in insect vector, S138

stochastic optimization method for estimation of spatial distribution of, 1184

striped mealybug as vector of, S73

structure and diversity of rhizosphere microbial communities and, S178

on sweet orange, tissue-specific host response to, $\mathrm{S} 181$

in vital organs of psyllid vector, localization of, S6

Ca. L. psyllaurus, on tomato, S113

Ca. L. solanacearum

on potato: effect of temperature on reproduction and titer level, S194; effects of temperature on, S162; endophytic bacteria in tubers and, S108; genome sequence analysis and functional predictions, S105; pathogenesis-related protein activity, host defense-associated secon- dary metabolite production and, S184; PCR assay for detection of, S190; translocation of, 1278

on tomato, translocation of, 1278

Candidatus phytoplasma spp.

Ca. P. asteris, on fruits and vegetables in Islamabad, S51

Ca. P. brasiliense, on guacimo, $\mathrm{S} 255$

Ca. P. mali, on apple, Cacopsylla picta and spread of, 1471

Ca. P. trifolii, passion fruit diseases and, S272

Candidatus spp., of potato in Yunnan, China, S44

Candresse, T., 611, 980

Cannon, P., S216

Cannon, P. G., S127

Canola. See Brassica spp.

Cantalapiedra-Navarrete, C., 1168

Cantaloupe. See Cucumis melo

Canto-Canché, B., S133

Cao, B., S176

Cao, J., 1202

Cao, S., S26, S83

Cao, X., S26

Capelluto, D. G., S230

Caplan, J., S116

Caplan, J. L., S76, S273

Capodilupo, M., S160

Capsicum chlorosis virus ( $\mathrm{CaCV})$

in vegetables, in India, 367

Capsicum spp.

C. аппиит (chili pepper)

emerging viral diseases of, S54

seaweed for suppression of root diseases of, S8

C. аппиит (Jalapeño pepper), Curly top virus in, $\mathrm{S} 154$

C. аппиит (pepper)

anthracnose forecaster for, S200

Begomovirus spp. in, whiteflies and, S210

Broad bean wilt virus 2 in, S199

Colletotrichum spp. on: C. acuatum, 666; compost water extracts for control of, 732; C. simmondsii, S88

Curly top virus in, $\mathrm{S} 154$

emerging viral diseases of, S54

Meloidogyne incognita on: co-infection with Phytophthora capsici and, S176; fluensulfone for control of, S97, S131

Phytophthora spp. on: biofungicides as transplant and soil treatment, S250; coinfection with Meloidogyne incognita and, S176; control by microbial and chemical fungicides, S74; fungicides for management of, S115; Revus drip application and, S94

Potato virus $X$ in, $\mathrm{S} 136$

Ralstonia solanacearum species complex on, resistance to, 154

seaweed extract for control of thrips on, S126

whiteflies vectoring geminiviruses in Indonesia, S150

Xanthomonas campestris pv. vesicatoria on, biological control of, S154

Colletotrichum spp. on, S175

Phytophthora capsici on, S43

Carbendazim, for Cercospora beticola on sugar beet, $\mathrm{S} 22$

Carbonari, C. A., S8

Carbone, I., 147, S147, 1373

Càrdenas, M., S120

Cardenas, M. E., S62

Cardwell, K. F., S161

Carey, A. B., S26

Carhuapoma, P., S57

Carica papaya (papaya)

Asperisporium caricae on, climate change and, S82

fungicides for control of postharvest diseases of, S133
Papaya leaf-distortion mosaic virus in, S198

Papaya ringspot virus in, S35, S198

Paracoccus marginatus on, biological control of, S85

Phytophthora palmivora on, disease tolerance gene identification, S82

successful introduction to transgenic virusresistant in Hawaii, S237

Carisse, O., S26, 696

Carlson, G. R., S73

Carner, G. R., S224, S225, S226

Carnes, M. E., S27

Carrillo-Tripp, J., S54

Carris, L., S13

Carroll, A. G., S27, S38, S49

Carroll, J. E., S27

Carrot. See Dauca carota

Carrot thin leaf virus (CTLV), in cilantro, S194

Carta, L. K., 480

Carter, D. H., S235

Cartwright, R., S156

Caruso, F. L., S168

Carvalho, D. D., S109

Carvalho, F. K., S8

Carvalho, R. A., S27, S28, S29

Carver, B. F., S157, 1322

Carya spp.

C. cordiformis (bitternut hickory), Ceratocystis smalleyi on

effect of multiple infections on stem water conductance, S245

hickory bark beetle and, S86

C. illinoensis (pecan)

Fusicladium effusum on: nickel and severity of, S193; phosphite for control of, S17; predictive model for, S267; QoI resistance monitoring and, S11; standard area diagrams for assessment of, S196; weather-based predictions for, $\mathrm{S} 138$

Phytophthora capsici on, S159

Xylella fastidiosa on, S267

Casassa, L. F., S4, S67

Caspase, potato- $P$. infestans interaction and, S52

Cassava. See Manihot esculenta

Cassava brown streak virus (CBSV), occurrence

and diversity in Tanzania, 1159

Castañeda-Martínez, T., S59

Castagnone- Sereno, P., 679

Castanea sp. (chestnut), Cryphonectria parasitica on, diversity of vegetative compatibility groups of, S170

Castell-Miller, C. V., S29

Castiblanco, L. F., S2.2

Castillo, J., S161

Castillo, J. D., S29

Castillo, P., 1168

Castillo, Y., S120

Castillo-Urquiza, G. P., S166

Castlebury, L., S56

Castro, R. M., S151

Castro Sparks, A., S183

Castro-Prado, M. A. A., 923

Casuarina equisetifolia (ironwood), Ganoderma spp. and Phellinus spp. on, S216

Catchot, A., S5

Catchot, A. L., S85

Catharanthus roseus, Phytophthora nicotianae on, S266

Catharidin, for control of Plutella xylostella, S84

Cating, R. A., S29

Cauliflower. See Brassica oleracea

CAVAR-Shock, food safety and, S217

Cavatorta, J., S64

Cavender-Bares, J., S245

Cavin, C. A., S272

CBSV. See Cassava brown streak virus

Cecílio, R. A., S81, S82

Cedar. See Toona ciliata

Cellulase activity

2-cyanoacetamide method for photometric 
assay of, S86

in sugarcane with Xanthomonas sacchari, S96 suppression of Phytophthora root rot in mulches and, 223

Celtis laevigata (sugarberry), sweet bunden of S206

Cennicola, M., S160

Centaurea solstitialis (yellow starthistle), S273

Cephalanoplos setosum, fungal pathogens for biological control of, S68

Cephalosporium spp., on wheat, cultivars with resistance against, $\mathrm{S} 18$

Ceratocystis spp.

C. fagacearum, on live oak, detection with rtPCR, S95

C. fimbriato

on eucalyptus: climate change and, S81; movement of genotypes within and among populations, 1005

genetic variation and variation in aggressiveness to native and exotic hosts among Brazilian populations, 555

on pomegranate, volatile organic compounds of, $\mathrm{S} 103$

C. smalleyi, on hickory

effect of multiple infections on stem water conductance, S245

hickory bark beetle and, S86

Cercospora spp.

C. beticola, on sugar beet, integrated disease

management for, $\mathrm{S} 22$

on hydrangea, $\mathrm{S} 12$

C. kikuchii, on soybean

cercosporin biosynthesis and, S30, S264

effect of mineral nutrients on, S269

foliar fungicides and, S241

fungicide efficacy and timing of application, S268

C. sojina, on soybean

azoxystrobin-resistant, S132

fungicide-resistant, S267

QoI-resistant populations, S2.9

survival on leaves, S203

C. zeae-maydis, on corn

abscisic acid production by, $\mathrm{S} 44$

foliar fungicides for control of, S242

genes involved in foliar infection, S72

quinone sensitivity and, S31

Cercosporin

genes involved in synthesis of, S30

light-induced proteins and synthesis of by Cercospora kikuchii, S264

Cereals. See also Specific cereals

Colletotrichum cereale on, detection from modern and historical collections, S14

Fusarium graminearum on, cinnamic-derived acids and, 929

long-term trials for controlling diseases in, S80

Polymixa graminis on, Peanut clump virus and, 1149

seed supply challenges in sub Saharan Africa, $\mathrm{S} 232$

Ceresini, P. C., S221

Cervone, T. R., S29

CesA3 gene mutations, Phytophthora capsici

herbicide resistance and, $\mathrm{S} 34$

CEVd. See Citrus exocortis viroid

Ch, R., S10

Cha, B., S91

Cha, J., S36

Chakrabarty, P. K., S30

Chakraborty, S., S53

Chaky, J. L., S46

Chalara elegans. See Thielaviopsis basicola

Chalupowicz, L., S136

Chamberlin, E. V., S73

Chamberlin, K., S30

Chambers, D., S177

Champaco, E. R., S30
Chan, C., S30

Chanda, A. K., S30, S264

Chanda, B., S230

Chandrasekar, G., S58

Chandrashekar, K. N., S145

Chang, C., S31, S41

Chang, H., S30, S105

Chang, K., S30, S106

Chang, P., S31

Chang, S., 750

Chang, T., S31

Chang, Y., S105, S242

Chansler, M. T., S170

Chantha, S., S3

Chao, C., S122

Chapara, V., S31

Chapman, K., S14

Chapman, K. S., S242

Charkowski, A. O., S31, S96, S114

Chase, T. E., S31, S242

Chastagner, G., S31, S32, S48, S247

Chatnaparat, T., S32, S146

Chavarria-Carvajal, J., S277

Che, H. J., 859

Cheatgrass. See Bromus tectorum

Chechetto, R. G., S8

Chellemi, D., S32

Chemical ecology, of plant-parasite interactions, S231

Chemosensory systems, Xylella fastidiosa on grape and, S10

Chen, C., S35, S66, S76, S180, S248

Chen, C.-L., 741

Chen, F., S34, S45

Chen, G., S206

Chen, H., S185

Chen, J., S33, S34, S41, S58, S101, S108, S184

Chen, K., S33, S35, S104, S198

Chen, L., S13, S32, S34, S203

Chen, M., S33, S34

Chen, P., S103

Chen, R., S264, S266

Chen, T., S140

Chen, T.-C., 367

Chen, W., S10, S33, S46, S67, S104, S148

Chen, X., S25, S32, S35, S108, S126, S140, S164,

S187, S198, S201, S205, S208

Chen, X. M., 544

Chen, Y., S34, S104, S195, S245, 263

Chen, Y.-R., 741

Chen, Z., S21, S30, S58, S208, S264

Cheng, C., S106, S108, S251

Cheng, D., S26, S83, S202

Cheng, H., S198

Cheng, J., S83

Cheng, M., S202

Cheng, P., S35, S201

Cheng, Y., S32

Cheong, E., S81

Cheong, S., S35, S90

Cherry. See Prunus spp.

Cherry leafroll virus (CLRV), in walnut, S111

Cherry rasp leaf virus (CRLV), genetic variability of, S142

Chestnut. See Castanea sp.

Chiang, C., S35

Chicapa Dovala, A., S277

Chickpea. See Cicer arietinum

Chickpea chlorotic stunt virus (CpCSV), in pea, S205

Chili pepper. See Capsicum annuит

Chilver, M. I., S2.8

Chilvers, M., S135, S2.9

Chilvers, M. I., S2.2

China

Monilinia spp. in, S76

recent advance of plant protection science in, S67

Chiroleu, F., 154, 887

Chitinase genes
Chromobacterium sp. biocontrol strain and, S231

from Pichia guilliermondii and Metschnikowia spp., S66

in rice, sheath blight disease resistance and, S100

in white pine, and resistance against Cronartium ribicola, 904

Chitosan, for management of early blight and

Septoria leaf spot in tomato, S51

Chitrampalam, P., S35, 358

Chittem, K., S35

Chitwood, D. J., 480

Chiu, Y., S76, S104

Chlorothalonil

for Alternaria solani on tomato, S2

Typhula ishikariensis and, S17

Chlorpyrifos, for control of coffee berry borer, S124

Cho, J., S36, S264

Cho, S., S36

Cho, W., S36

Cho, Y., S36

Choi, D., S92

Choi, H., S36, S74, S91, S113

Choi, I., S182

Choi, K., S100

Choi, S., S198, S199

Choudhary, N., S36, S156

Chowdappa, P., S164

Chowpongpang, S., S44

Christ, B., S48

Christ, B. J., S188

Christ, D. S., 1330, 1338

Christensen, S., S230

Christiano, R., S37

Christmas trees, current season needle necrosis in, S31

Chromobacterium spp. chromomycin from, S231

for control of Phytophthora cinnamomi on cranberry, S168

Chromolaena odorata, extract of for control of

Rhizoctonia solani on rice, 231

Chromomycin, identification of from Chromo-

bacterium sp., S231

Chrysanthemum spp. (pyrethrum)

Phoma ligulicola var. inoxydabilis on, 1112

Puccinia horiana on, S91

Stagonosporopsis ligulicola on, S141

yield estimation by digital image analysis, S162

Chrysocoris javanus, on jatropha, S115

Chrysophanol, from Trichoderma harzianum, S106

Chrysorhiza spp., on seashore paspalum, S87

Chua, K., S121

Chuaboon, W., S37, S146

Chuaqui, H., S99

Chun, S., S36

Chung, E., S15

Chung, W., S34, S37

Chung, Y., S15

Chung, Y. S., 205

Ciboria shiraiana, on mulberry, S35

Cicadulina bipunctata (gall-inducing leafhopper) on corn, maize wallaby ear symptoms on, S116

on wheat, effect of barley chromosome addition, S94

Cicer arietinum (chickpea)

Asochyta rabiei on, detection of fungicide resistance and, S62

Clonostachys rhizophaga on, S46

Fusarium oxysporum f. sp. ciceris on, resistance to, 250

new broad-spectrum fungicide for, $\mathrm{S} 115$

Cilantro. See Coriandrum sativum

Cilia, M., S63

Cinnamic-derived acids, Fusarium graminearum and, 929 
Cirsium arvense (Canada thistle), Puccinia punctiformis for control of, S39, S258

Cisneros, F., S37

Citricolin, Phytophthora plurivola production of,

localization in roots of European beech, S40

Citrullus lanatus (watermelon)

Acidovorax citrulli on, S182, S265

asafoetida and seaweed for management of root diseases of, $\mathrm{S} 47$

Cucurbit chlorotic yellows virus in, $\mathrm{S} 139$

Didymella bryoniae on, S89, S269

Fusarium oxysporum f. sp. niveum on, S50, S72, S159, S204

Phytophthora spp. on, S94, S268

sorghum as barrier and intercrop option against viruses in, S276

Tomato yellow leaf curl virus and Watermelon chlorotic stunt virus in, $\mathrm{S} 122$

Citrus black fly. See Aleurocanthus woglumi

Citrus canker, species causing, S48

Citrus exocortis viroid $(C E V d)$, replication of in citrus protoplasts, $\mathrm{S} 69$

Citrus greening. See Candidatus Liberibacter asiaticus

Citrus leprosis virus cytoplasmic type (CiLV-C) detection and identification methods for, S125 detection of, S36

Citrus red mite. See Panonychus citri

Citrus spp.

Aleurocanthus woglumi on in Brazil, S27, S28, S29

Alternaria alternata on

evolutionary history and species boundaries of, S171

QoI-resistant isolates, S182

C. aurantifolia (Mexican lime), Xanthomonas citri subsp. citri on, comparative host responses to narrow and broad host range strains, S84

Candidatus Liberibacter asiaticus on chemical compounds effective against, 1097

colonization of seed coats, 1242

seasonal fluctuation of titers, S110

seasonal variation in branches and in insect vector, $\mathrm{S} 138$

in Texas, $\mathrm{S} 95$

Citrus leprosis virus cytoplasmic type $C$ in

detection of, S36, S125

Citrus tatter leaf virus in, S175

Elsinoe australis on, in USA, S95

Guignardia citricarpa on, S54, S76

Guignardia mangiferae on, S76

C. japonica (kumquat), Xanthomonas citri subsp. citri on, early activation of defense genes in, S51

lime, Xanthomonas citri subsp. citri on, comparative host responses to narrow and broad host range strains, $\mathrm{S} 84$

C. limon (lemon), Aleurocanthus woglumi on in Brazil, S28

C. macrophylla (alemow), Xanthomonas citri subsp. citri on, comparative host responses to narrow and broad host range strains, S84

Neofusicoccum mangiferae on, S48

Panonychus citri on, S186

C. paradisi (grapefruit), Xanthomonas citri subsp. citri on, S17, S55, S84

Penicillium spp. on, postharvest evaluation of chemicals as inducers of resistance against, S124

protoplast culture of, study of Citrus exocortis

viroid replication in, S69

quick decline of in California, S48

C. sinensis (orange)

Aleurocanthus woglumi on in Brazil, S27, S28, S29

Candidatus Liberibacter asiaticus on, tissue-specific host response to, $\mathrm{S} 181$

Elsinoe australis on, in USA, S95 foamy bark rot of, S2

Xanthomonas citri subsp. citri on, S55

Xylella fastidiosa on, biologic and sym-

biotic control of using endophytic bacteria, S96

C. $\times$ tangerina (tangerine), Aleurocanthus woglumi on in Brazil, S28

Xanthomonas spp. on

$X$. axonopodis: Bacillus subtilis for control of, S76; comparative genomic analysis of, S80

$X$. citri subsp. citri: comparative host responses to narrow and broad host range strains, S84; role of XAC1496 on growth and pathogenesis of, S75; transposon mutagenesis for identification of virulence factors, S196

Xylella fastidiosa on

biologic and symbiotic control of using endophytic bacteria, S96

detection and discrimination of, $\mathrm{S} 135$

yellow vein and vein enation disease in, S87

Citrus tatter leaf virus (CTLV), in citrus, S175

Citrus tristeza virus (CTV)

in citrus in California, $\mathrm{S} 48$

cross protection and, $\mathrm{S} 43$

expression of Candidatus Liberibacter asiati-

cus hemolysin with, S68

trifoliate resistance breaking genotype of, S156

Citrus variegated chlorosis. See Xylella fastidiosa subsp. pauca

Citrus yellow vein disease, viruses associated with, S87

Civerolo, E., S41, S108

Civerolo, E. L., S105

Cladosporium caryigenum. See Fusicladium effusum

Cladosporium spp.

on blueberry, epiphyte populations and, S99 on passion fruit, S174

Clark, C. A., S270

Clark, R., S246

Clark, R. A., S60

Clark, W. D., S87

Clarke, B. B., S14, S129, S204, S211, S259

Clarke, C. R., 847

Clavibacter michiganensis

ssp. nebraskensis

on corn, commercially available tests for, $\mathrm{S} 2.5$

on tobacco, silencing of host basal defense response-related gene expression and, 349 on tomato: bioluminescent, colonization under different humidity regimes, S194; detection of, S133; new selective medium for isolation of, 1355 ; purified fire ant venom alkaloids for control of, S101

novel isothermal nucleic amplification for

detection and identification of, S157

on tomato

biological control of, S98

bioluminescent, colonization under different humidity regimes, S194

detection of, S133

multivariate matrix for tracing in greenhouse operations, S101

new selective medium for isolation of, 1355

purified fire ant venom alkaloids for control of, S101

Clavibacter spp., nicking enzyme amplification reactions for detection of, $\mathrm{S} 215$

Claviceps spp., ergot alkaloid synthesis gene cluster in, S53

Clement, D. L., S73, S117

Clemente, T. E., 1264

Clerodendrum golden mosaic China virus

(ClGMCNV), on salvia, S181

Cleveland, K. M., S60

ClGMCNV. See Clerodendrum golden mosaic
China virus

Climate change

Asperisporium caricae on papaya and, S82

Ceratocystis fimbriata on eucalyptus and, S81

emerging viral and weed threats and, S240

future plant disease and vector threats and, S53

management of Parthenium hysterophorus and, S238

mycotoxigenic fungi pathogenesis and, S222

plant protection, food security and, S239

Cline, W. O., S115

Clock vine. See Thunbergia laurifolia

Clonally propagated crops, overcoming poor seed

systems for in developing countries, S232

Clonostachys spp.

on chickpea, S46

for control of Fusarium spp. on wheat, S194

Closteroviruses

biology and molecular biology of, S229

in Hawaiian ti, S119

Clough, S., S25, S186

Clough, S. J., S149

Clove extract, for Rhizoctonia spp. and Sclerotium

hydrophilum on rice, $\mathrm{S} 11$

Clover. See Trifolium spp.

CLRV. See Cherry leafroll virus

Cluskey, S. A., S71

CMR12a. See Pseudomonas CMR12a

Coakley, S. M., S240

Coat protein, of Plum pox virus, analysis of epitope structure of, 611

Coates, B., S55

Coats, K., S32

Coats, K. P., S48, S247

Cochliobolus spp.

C. miyabeanus, on wild rice, $\mathrm{S} 29$

C. sativus

on barley, S5, S259

on wheat, S5, S2.8

on turfgrasses, $\mathrm{S} 177$

Cochran, A., S37

Cochran, K., S38

Coconut cadang-cadang viroid (CCCVd), in oil palm, S85

Coconut rhinoceros beetle. See Oryctes rhinoceros

Cocos nucifera (coconut palm)

Oryctes rhinoceros on, S219

Rhynchophorus ferrugineus on, S3

Cody, M., S129

Coers, L. M., S134

Coffea arabica (coffee)

endophytic bacteria from vascular tissue of, S278

Tobacco mosaic virus as expression vector in,

weeds and insects with potential as hosts and vectors of disease agents of, S276

witches broom and other diseases of, S276

Coffee berry borer. See Hypothenemus hampei

Coffey, M. D., S16, S116

Cohen, Y., S38

Coker, C. M., S38

Colburn, G., S38

Colburn-Clifford, J., S38

Cold plasma. See Plasma technology

Colgrove, A. C., S110

Collard greens. See Brassica oleracea

Colletotrichum spp.

C. acutatum

on almond, 1013

on apple, S2.5

on blueberry, S120

diversity of vegetative compatibility reactions existing among isolates of, 923

genetic diversity in South Korea, S91

on lupin and tamarillo, S5

on pepper, 666

on strawberry, S27, S140

on Capsicum spp., S175

C. cereale 
on bluegrass, S259

on cereals, $\mathrm{S} 14$

sensitivity to penthiopyrad, S261

on turfgrasses, S111, S187

C. coccodes

genetic diversity of global population, S241

on potato, S78, S193

field evaluation of forecaster for, S200

C. gloeosporioides

on apple, fungicide sensitivity of, S2.5

on avocado, $\mathrm{S} 128$

on broccoli, glucoraphane and, S98

on grape, identification and virulence

differentiation, S103

on papaya, $\mathrm{S} 133$

on persimmon, in Brazil, S17

on strawberry, S203

C. graminicola, on Miscanthus sinensis, S260

C. higginisianum, on Brassica rapa, Apphark-

nessia sp. for control of, S37

C. lindemuthianum, genetic analysis of the

resistance to in common bean, 757

on mango, S255

on pepper and cucumber, compost water

extracts for control of, 732

C. simmondsii, on sweet pepper, $\mathrm{S} 88$

on soybean, identification and analysis of, S197

C. sublineolum, on sorghum, $\mathrm{S} 140$

on switchgrass, S61

on tropical fruit in postharvest, cross-infection of, S3

C. truncatum, on soybean, $\mathrm{S} 242$

Collinge, D. B., 231, 960

Collins, D., S38

Collins, D. J., S146

Colocasia esculenta (taro)

beetles of in Pacific Islands, S219

Phytophthora colocasiae on, screening for resistance, $\mathrm{S} 21$

Columbia root-knot nematode. See Meloidogyne chitwoodi

Coly, E. V., S228

Compost water extracts, biocontrol activity and

primed systemic resistance by, against anthrac-

noses of pepper and cucumber, 732

Composts

control of plant pathogens by microorganisms isolated from, S66

for Phytophthora cinnamomi on avocado, S278

Comstock, J. C., S61

Conaway, S. A., S39, S258

Conceiç̧ão, C. S., S166

Coneflower. See Echinacea pallida

Confais, J., 1433

Cong, B., S39

Conidiobolus thromboides, on soybean, S153

Conifers, western corn rootworms on, S2.4

Coniothyrium minitans

for control of Sclerotinia sclerotiorum on soybean, S126, S245, S2.4

new strain from Iowa, S2.4

and Sclerotinia minor on lettuce, 358

Conley, S., S191

Connell, J., S54

Conner, R., S30

Constable, F., S53

Constantelos, C., S143

Contans. See Coniothyrium minitans

Contreras, F., S49

Conway, W. S., S86, S141, S183

Cook, D., S5

Cooksey, D. A., S165

Coop, L. B., 644

Cooper, G. T., S39

Copes, W. E., S39

Copper

and kasugamycin for walnut blight man- agement, S2

microplate assay for Xanthomonas spp. resistance to, S75

for Pseudomonas syringae pv. phaseolicola on snap bean, S202

Xanthomonas oryzae on rice and, S207

Coptotermes formosans, electronic-nose for detection and discrimination of, S192

Coram, T., S2.9

Cordero, F., S134

Cordyline fruticosa (ti plant), Closteroviruses in, S119

Coriandrum sativum (cilantro), Carrot thin leaf

virus in, $\mathrm{S} 194$

Corn. See Zea mays

Corn planthopper. See Peregrinus maidus

Corn thrips. See Frankliniella williamsi

Cornejo, M., S138

Cornus florida (dogwood), powdery mildew on,

biological control of, S112

Corral, R., S183

Correa, M. R., S8

Correll, J. C., S52

Cortada, L., 410

Côrtes, M. V., S167

Cortes-Barco, A., S211

Corylus avellana (hazelnut)

Anisogramma anomala on, S25, S71, S123

Fusarium lateritium on, 679

Corynespora cassiicola, on hydrangea, S121

Cosmi, F. C., S82

Costa, R. V., S152

Costadone, L., S39

Costelytra zealandica, Serratia entomophila for

control of, $\mathrm{S} 224$

Côté, C., S260

Cotton. See Gossypium spp

Cotton leaf curl virus (CLCuV), in cotton, isolate

diversity, breakdown of resistance and, S30

Cotty, P. J., S80, S133, S225, S250

Cottyn, B., S193

Couto, M. E., S115

Cover crops

Brassica spp., for Fusarium oxysporum f. sp. niveum on watermelon and Rhizoctonia solani on rice, $\mathrm{S} 204$

effect of on nematode population density in tomato, S120

Fusarium oxysporum f. sp. niveum on watermelon and, S72

leguminous, as hosts for Verticillium dahliae, S109

root health, vegetable yield and, S1

sunn hemp for suppression of Rotylenchulus reniformis, $\mathrm{S} 113$

Covey, P. A., S2.5

Cowger, C., 323

Cowpea mild mottle virus (CpMMV), in soybean

in Nigeria, S78

Cox, K., S80

Cox, K. D., S27, S76, S128

Coyne, D. L., S225, S232

CpCSV. See Chickpea chlorotic stunt virus

Craig, A., S138

Cramer, C. S., S12

Cranberry. See Vaccinium macrocarpon

Crane, J., S39

Cranshaw, W., S55, S138, S168, S201

Creamer, R., S2, S14, S102, S104

Creary, E., S176

Creeping bentgrass. See Agrostis stolonifera

Cregan, P. B., 535

Creswell, T., S244

Criniviruses, whiteflies vectoring in Costa Rica, S151

CRISPR arrays, for species diversity evaluation and microbial source tracking, S118

CRLV. See Cherry rasp leaf virus

Cromer, J. P., S42

Cronartium ribicola, on white pine, chitinase gene and resistance against, 904

Crop loss

assessment of, S223

in highly populated areas, S223

impacts on science, production, and society, S223

Crop rotation

disease-suppressive Brassica rotation crops and potato, $\mathrm{S} 98$

Heterodera glycines on soybean and, S2.8

Rhizoctonia solani on beet and, S19

rice kernel smut and, $\mathrm{S} 7$

for suppression of nematodes on strawberry, S160

Cropping sequence, in peanut

comparison of soil fungal community structure using ribosomal intergenic spacer analysis in relation to aflatoxin-producing fungi, 52

exploring using multiple molecular approaches, 819

Cross protection, Citrus tristeza virus and, S43

Crosslin, J. M., S88, 778

Crotalaria juncea (sunn hemp), as cover crop for suppression of Rotylenchulus reniformis, S113

Crouch, J., S14, S211

Crow, J. A., S208

Crozier, J., S272

CRT1 gene family, Arabidopsis pathogen immunity and, S113

Crucifers

Pseudomonas cannabina pv. alisalensis on, S157

Xanthomonas campestris pv. campestris on, S260

Cruz, C. D., S40, S141, S220

Cruz-Gonzalez, A. G., S276

Cruz-Hernández, M. A., S128

Cry toxins, Bombyx mori gut bacteria and, S103

Cryphonectria parasitica, on chestnut, diversity

of vegetative compatibility groups of, $\mathrm{S} 170$

Cryptococcus flavescens

for control of Fusarium graminearum on wheat, S160

for control of Fusarium spp. on wheat, S200

Csinos, A. S., S79, S125

CSNN. See Current season needle necrosis

Cuadrado, I. M., 1365

Cubeta, M. A., 147

CucEV-1. See Cucumis endornavirus I

Cucullo, J., S251

Cucumber. See Cucumis sativus

Cucumber mosaic virus (CMV)

comparative analysis of Korean isolates, S91

functional analysis of $2 b$ protein, S126

and QTL of soybean cultivars, multigenic system controlling viral systemic infection determined by, 575

in snap bean, novel satellite RNA associated with, S130

in soybean in Nigeria, $\mathrm{S} 78$

virus-like particles of as chemical bio-conjugate substrates, S126

in yam, in West Africa, S48

Cucumber vein yellowing virus (CVYV), in zucchini, 1365

Cucumis endornavirus I (CucEV-1), molecular characterization of, $\mathrm{S} 158$

Cucumis spp.

C. melo (cantaloupe) Erwinia tracheiphila on, colonization through flower inoculation, S59

Pseudoperonospora cubensis on, temperature and wetness parameters and, S127

C. melo (melon) Cucurbit chlorotic yellows virus in, S139 Monosporascus cannonballus on, 794 novel Nepovirus sp. on, in Japan, 316 Tomato leaf curl New Delhi virus in, factors controlling mechanical transmissibility of, S30 
C. melo (muskmelon), Erwinia tracheiphila on, $\mathrm{S} 158$

C. sativus (cucumber)

Colletotrichum spp. on, compost water extracts for control of, 732

control of diseases using hot water extract from spent substrate of edible mushrooms, S136

early warning method for diseases in solar greenhouses, S197

Erwinia tracheiphila on, S158

Fusarium oxysporum on: f. sp. radiciscucumerinum, soil suppressiveness in organic-amended soil, S91; nonpathogenic, control of Fusarium wilt disease and, S37

Meloidogyne incognita on, fluensulfone for control of, S97

powdery mildew on, screening biological isolates for control of, S111

Pseudoperonospora cubensis on: sexual reproduction of, S38; temperature and wetness parameters and, S127

Pythium ultimum on, 271

seaweed extract for control of thrips on, S126

C. sativus (gherkin), Phytophthora capsici on, S43

Cucumoviruses, in chili pepper fields, S54

Cucurbit aphid-borne yellows virus (CABYV)

multiplex RT-PCR for detection of mixed infections with, S163

protein-protein interaction of, $\mathrm{S} 32$

Cucurbit chlorotic yellows virus (CCYV), in

melon and watermelon, S139

Cucurbit downy mildew. See Pseudoperonospora cubensis

Cucurbit yellow stunting disorder virus (CYSDV), in zucchini, 1365

Cucurbita pepo (pumpkin, squash, zucchini) Cucurbit yellow stunting disorder virus and Cucumber vein yellowing virus in, 1365

Didymella bryoniae on, S89

Erwinia tracheiphila on, S158

Phytophthora spp. on

molecular characterization and fungicide sensitivity, S268

Revus drip application and, S94

Podosphaera xanthii on, S261

Pseudoperonospora cubensis on, temperature and wetness parameters and, S127

sooty blotch and flyspeck on, S2.6

transgenic, S237

Xanthomonas cucurbitae on, in Illinois, S12

Cucurbits

Acidovorax avenae on, S196

Cucumis endornavirus I (CucEV-1) in, S158

Cucurbit chlorotic yellows virus in, S139

Cucurbit yellow stunting disorder virus and Cucumber vein yellowing virus in, 1365

Erwinia tracheiphila on, host specificity of S158

fungicide resistance in powdery mildew populations, S99

Meloidogyne javanica on, MCW-2 for management of, S190

multiplex RT-PCR for detection of mixed yellows virus infections in, S163

Pseudoperonospora cubensis on, sexual reproduction of, S38

sooty blotch and flyspeck on, S2.6

Squash leaf curl virus and Watermelon chlorotic stunt virus in, 281

Cuellar, W. J., S215

Cui, W., S97

Cui, X., 1104

Culbreath, A., S66

Cummings, D., S172

Cunha, F., S224

Cunniffe, N. J., 725
Cunningham, M., S62

Cuomo, C., S208

Cupressus macrocarpa (cypress), Seiridium car dinale on, California as likely source of epidemic in Mediterranean region, 1408

Curlango-Rivera, G., S40

Curly top virus, in Jalapeño pepper, S154

Currants. See Ribes spp.

Current season needle necrosis (CSNN), in

Christmas trees, S31

Cursino, L., S10

Curtobacterium flaccumfaciens, Xylella fastidiosa on citrus and, S96

Curtoviruses

effect of host plants on single and mixed infections, S192

quantification and differentiation in mixed viral infections, S139

recombination and evolution and emergence of new, S32

in spinach, isolation of new, S20

Curvularia lunata, on corn

differential proteins and genes induced by resistant germplasm, S33

genetic differentiation and resistance evaluation, S147

Cuscuta campestris (field dodder), selective and non-selective management of, S239

Cusicanqui, J., S62

CVYV. See Cucumber vein yellowing virus

CWE. See Compost water extracts

Cybrids, Xanthomonas citri on citrus and, S55

Cyclic lipopeptides, biological control of Rhizoctonia solani on bean and, 996

Cyclopiazonic acid, in corn, reduction of by

biocontrol strains of Aspergillus flavus, S1

Cycloxaprid, metabolism and stability of, S194

Cylandrocladium spp., on peanut, prothioconazole

for management of, S19

Cylindrocarpon spp., on almond and peach, S15, S160

Cymbidium mosaic virus (CymMV), in orchids elimination of, $\mathrm{S} 187$ molecular method for detection of, S26

Cymene, Rhizoctonia and Pythium spp. spore germination and, S109

Cynanchum spp. (swallow worts), leaf anthracnose for control of, S272

Cynodon dactylon (bermudagrass), Ophisphaerella

korrae on, S177

Cypermethrin, degradation of by Rhodopseudomonas palustris isolated from contaminated sludge, S106

Cypress. See Cupressaceae

CYSDV. See Cucurbit yellow stunting disorder virus

Czymmek, K. J., S76, S116, S273

da Graça, J. V., S95, S175

da Silva, W. L., S264

Dababat, A. A., S226

D'aes, J., 996

Dahlia common mosaic virus (DCMV), promoter elements from, S5

Dahlia mosaic virus (DMV), promoter elements from, S5

Dahlia sp., pararetroviruses of, promoter elements

from, S5

Dahm, S., 1176

Dai, L., 620

Dakouo, D., S130

Dale, A. L., 68

Daleo, G. R., S52

Dalio, R., S40

Dalio, R. J., S40

Dallagnol, L. J., 92

Dally, E. L., S272

Damann, K. E., Jr., 952

DaMatta, F. M., 92

Damayanti, T. A., S143
Damicone, J., S40

Damicone, J. P., S265

Damsteegt, V. D., 627

Dandekar, A. M., 1311

Dangl, G. S., S61

Daniels, J., S41, S50, S171

Danti, R., 1408

Danyluk, M. D., S212

Dao, S., S193

Dark septate endophytes, shaping of plant communities by, S151

Darluca sp., on switchgrass, S61

Das, M., S239

Datura spp.

Iris yellow spot virus and Tomato spotted wilt virus in, genetic complementation and, S12

Iris yellow spot virus in, characterization of distinct strains, $\mathrm{S} 12$

D. stramonium, as model to study systemic acquired resistance from Iris yellow spot virus, $\mathrm{S} 178$

Dauca carota (carrot)

Alternaria radicina on, $\mathrm{S} 178$

Meloidogyne javanica on, MCW-2 for management of, S190

Pythium spp. on, S110

Xanthomonas hortorum pv. carotae on, S194

Daughtrey, M. L., S258

Daugovish, O., S79

Daunay, M.-C., 154

Dave, A., S172

Davelos Baines, A. L., S170

Davenport, F., S96

Davidson, J. M., 492

Davis, C. D., S116

Davis, D. D., S88, S89

Davis, E. W., S231

Davis, J. A., S270

Davis, M., S52

Davis, M. A., S18

Davis, R. E., S77, S214, S272, S273, S275

Davis, R. F., S265, S266

Davis, R. M., S110

Dawson, W. O., S81, S229

Day, B., S2.5

Daylily. See Hemerocallis spp.

DCMV. See Dahlia common mosaic virus

De Beer, W., S204

de Jonge, R., S208

de Kievit, T., S102

de la Cerda, K. A., 85

de los Reyes, B., S30

De Maeyer, K., 996

de Moraes, C., S119

De Moraes, C. M., S231

de Sa Snow, P. B., S95

de Vega-Bartol, J. J., 470

de Vos, S. M., S196

De Wolf, E., S170, 640

Deahl, K. L., S41

Deardorff, J. J., S124

DeBauw, A., S48, S247

Debenport, S., S41

Decision support systems (DSS)

and integrated pest management, perceptions of risk, risk aversion, and barriers to adoption of, 640

for management of downy mildew in vineyards, S24

for multiple-decision disease management as affected by weather input errors, 644

perceptions of risk, rational decision-making and, 654

Decline, as disease category, utility of, 404

Deep, S., S164

Deepthi, K., S62

Dehne, H., S65

Dehnen-Schmutz, K., 392

Dekena, D., 980

del Rio, L., S127 
del Río, M. L., S10

del Rio Mandoza, L. E., S144, S147

del Rio Mendoza, L., S245

Del Rio Mendoza, L. E., S2.1

Delfosse, P., S47

Delgado, J. A., S62

Della Rocca, G., 1408

Demarino, Y. M., S22

Demethylation inhibitor fungicides, for Sclero-

tinia homeocarpa on turfgrass, S25

Demirci, F., S150

Demon, I., 725

Deng, J., S103

Deng, W., S31, S41

Deng, X., S41, S58

Denight, M., S23

Denny, T., S67

Deoxynivalenol (DON)

Clonostachys rosea strain ACM941 for control of in wheat, S194

Fusarium graminearum and on barley: effect of fungicides, S259; swathing vs. straight-cut combining and, S64 on wheat, gene expression and, 1091

Fusarium spp. and, on corn, S18, S22

inoculation timing, mist duration, and isolate effects on, S244

dePamphilis, C., S239

Derera, J., S124

Dermastia, M., 1292

Derycke, S., 1168

DeSouza, S. P., S89

DesRochers, P., S262

Detemmerman, L., S193

Detergent, for Aleurocanthus woglumi on citrus in

Brazil, S27, S28

Developing countries, production and distribution of quality planting materials, seed, and seed systems in, S232

Dewdney, M., S76, S138

Dewdney, M. M., S182

Dewhurst, C. F., S219

Dey, K., S229

Dey, K. K., S42

Dhileepan, K., S238

Dhillon, B., S208

Dhiman, C., S128

Di, D., S82

Di, R., S215

Diabrotica spp.

D. barberi (northern corn rootworm), diapause in, S55

D. virgifera (western corn rootworms) on conifers, S2.4 on corn, $\mathrm{S} 182$

Diamondback moth. See Plutella xylostella

Diaphorina citri (Asian citrus psyllid)

Candidatus Liberibacter asiaticus and detached-leaf assay for testing inoculativity of, S6

differentially expressed virulence genes, S170

localization of in vital organs, S6 metagenomic analysis using BAC libraries, S205

in Pakistan, S151

seasonal variations, $\mathrm{S} 138$

Diaporthe spp., on soybean, S31, S103, S242

Diaporthe/Phomopsis complex, associated with

Blueberry, S99

Dias, A., S93

Diaz, G. A., S42, S99

Diaz-Arias, M., S42

Díaz-Mínguez, J. M., 470

Dibiyantoro, A., S150

Dicamba, soybean and glyphosate-resistant weeds, S236

Dicarboximides, resistance of Botrytis cinerea against, S56

Dicentra spectabilis, Tobacco rattle virus in, molecular characterization of, $\mathrm{S} 154$

Dickeya spp. See also Pectobacterium chrysanthemi

on Oncidium spp., S29

type III secretion system of, S206

Dickinson, M., S53

Dickman, M. B., S86, S122

Dickson, D. W., S265

Dickstein, E. R., S130

Didymella spp.

on faba bean, S135

on watermelon, S89, S269

Didymellaceae, heterothallism in, S2.2

Diéguez-Uribeondo, J., 1013

Dienelt, M. M., S181

Dieryck, B., 1149

Dietrich, L. E. P., 996

Difenoconazole, Fusicladosporium carpophilum and Alternaria spp. on almond and, S54

Digennaro, P. M., S42

Digitaria spp., haloxyfop-methyl for control of, adjuvants, rain-free period and, $\mathrm{S} 8$

DiGuistini, S., S188

Dill, G. M., S47

Dill, J. F., S47

Dimocarpus longan (longan), pathogenic and non-pathogenic fungi associated with, S163

Dinakaran, D., S42, S56, S227

Dinesh Kumar, V., S145

Ding, M., S43

Ding, Y., S272, S275

Dingha, B. N., S53

Dintinger, J., 154

Dioscorea spp. (yam), overcoming poor seed systems for in developing countries, S232

Diospyros spp. (persimmon)

Colleotrichum gloeosporioides and Pestalotiopsis sp. on, in Brazil, S17

Mycosphaerella nawae on, leaf wetness duration requirements of, 1346

Diplodia spp.

on grape, S39

on pine, 334

Distribution, spatial, stochastic optimization method

for estimation of, 1184

Dita, M., S43, S142

Dithane, assessment of rainfastness and efficacy

of formulations, S2.6

Ditomaso, J. M., S238

Dittapongpitch, V., S186

Djalilov, F., S78

Djeddour, D., S179

Djeddour, D. H., S95

DMV. See Dahlia mosaic virus

DNA arrays, in plant pathogen detection, S214

DNAse signals, non-host plant defense against multiple pathogenic fungi and, S68

Do, H., S149

do Carmo, F. R., S43

Dobbs, J., S60

Dobesh, S., S73

Dobhal, S., S43, S59

Dobinson, K. F., S208, S250, S251

Doddapaneni, H., S43

Dodder. See Cuscuta campestris

Dodine, tank mixing of for apple scab, S80

Doerksen, T., S166

Dogwood. See Cornus florida

Dolezal, W. E., S46, S232

Dollar spot. See Sclerotinia homeocarpa

Domier, L. L., S86, 750

Dominguez, R. M., 470

DON. See Deoxynivalenol

Donald, P., S26

Dong, D., S107

Dong, H., S39

Dong, J., S44, S51

Dong, W., S202

Dong, W. B., S22

Donna, C. R., S44
Donner, M., S44

Donnua, S., S44

Donofrio, N., S5, S48

Donofrio, N. M., S76, S94, S116, S150, S273

Dor, E., 213

Dorigatti, I., 392

Dorleku, W., S44

Dornbusch, M. R., S29

Dorrance, A., S66, S100, S190

Dorrance, A. E., S48, S186, 1264

Dothistroma septosporum, on pine, sexual reproduction and gene flow of in British Columbia, 68

Dotson, A., S94

Dou, D., S230

Dou, W., S186

Douce, G., S161

Douce, G. K., S73

Doucet, D., 1149

Douhan, G. W., S35, 85, S135, S178

Doustseddigh, H., S44

Draper, M. A., S45, S73

Dreo, T., S19, S45

Drew, J. C., S77

Drift, aerial application and, S8

Drippy nut pathogen. See Brenneria quercina

Driscoll, W. W., S45

Driver, J., S108

Driver, J. G., S45, S173

Drought tolerance, Sebacina vermifera, switchgrass and, S60

Druffel, K., S68, S121, S164

Druffel, K. L., S182

Dry beans, disease prevalence and distribution in Nebraska, S70

Du, Y., S45

du Toit, L. J., S4, S194, S247, S248

Dual use dilemma, overview of, S217

Duan, X., S26, S45

Duan, Y., S68, S73, S202, S205, S206

Duan, Y. P., 1097

Dubler, W. D., S142

DuBose, V., S89

Dudley, N. S., S216

Duff-Farrier, C., S46

Duffy, B., S19, S45, S144, S145, S146, S232, 1234

Duffy, S., 445, 1136

Dugan, F. M., S46

Duisembekov, B., S177

Dull, A. J., S92

Dumroese, R., S171

Duncan, R. W., 425

Dunfee, A. P., S73

Dung, J. K., S46, S247

Dunkle, R. L., S46, S217

Dunlap, C. A., S160

Dupont, J., 1433

Durairaj, C., S227

Durand, M., S262

Duressa, D., S46

Durham, T., S48

Durrin, J. S., S47

Dutky, E. M., S117

Dutta, B., S183, S265

Duveiller, E., S168, S220, S223

Dwyer, J. D., S47

Dyer, A. T., S73

Dymiococcus spp. (mealybugs), Pineapple mealybug wilt associated viruses and, S229

Early Detection \& Distribution Mapping System, overview of, S96

Earworm. See Helicoverpa zea

Eastburn, D. M., S203

Eastern filbert blight. See Anisogramma anomala

Eberhart, J. E., S137

Ebert, T., S138

Ebmeyer, E., 1209

Ebner, M. R., S274 
Echinacea pallida (coneflower), phytoplasma on, S139

Echizenya, I., 575

Ectropis oblique nucleopolyhedrovirus (EoNPV), for control of tea looper, S194

Ectropis oblique (tea looper), on tea, S194

Edema, M. J., S218

Edgerton, T., S74

Edmunds, A. C., S2.2

Education, integrated pest management and, S234

Edwards, H. H., 894

Edwards, J. T., S132, S157

Edwards, M. C., S47

Effector proteins, PI-3-P and entry of into host cells, S230

Egel, D., S50

Egg-carrying behavior, termite control strategy

based on, S233

Eggenberger, S., S274

Eggplant. See Solanum melongena

EHEC (enterohemorrhagic E. coli). See E. col O157:H7

Ehr, B., S2.6

Ehteshamul-Haque, S., S8, S47, S173

Eid, S., S47

eIF4E genes, and Potato virus $Y$ resistance, S64

Eigenbrode, S. D., S182

Ejeta, G., S232, S238

Ekesi, S., S224

Ekperigin, M. M., S6

Ekramoddoullah, A. K. M., 904

El Jarroudi, M., S47

El Mounadi, K., S48

E1 Salamouny, S., S225

Elaeis guineensis (oil palm)

bacterial and fungal pathogens associated with, S131

Coconut cadang-cadang viroid in, $\mathrm{S} 85$

control measures for lethal wilt of, S255

Ganoderma spp. on, S254

molecular identification of microorganisms associated with, S254

Oryctes rhinoceros on, S219

pests of in Papua New Guinea, S219

Phytophthora palmivora on, S253, S254

Pseudomonas aeruginosa on, induced resistance and, S192

Rhynchophorus palmarum and Bursaphelenchus cocophilus on, $\mathrm{S} 254$ sudden wilt of, S253

Electronic nose technology

for detection of Burkholderia cepacia on onion, S189

for detection of termites in wood, S192

Elena, S. F., 1136

Elixirs of life, searching for new, S96

Elkahky, M. T., S13

El-Kassaby, Y., S51

Elling, A. A., S214

Elliott, M., S32, S48, S247, S248

Elliott, N. C., S157

Ellis, M. A., S22

Ellis, M. L., S48

Elmer, W. H., S48, S258

Elsinoe spp.

E. ampelina, on grape, S26, S169

E. australis, on sweet orange, S95

Elution-independent collection device, for rapid sampling for PCR assays, S44

Embellisia astragali, on Astragalus adsurgens, S102

Emerson, M., S267

Emerson, M. J., S27, S38, S49

Emmett, R. W., S169

Encapsulation methods, for carbon dioxide attractants and plant extracts as plant protection products, S182

Encarsia sophia, as whitefly parasitoid, S185

Endo, N., S49

Endoglucanase inhibitor proteins, of potato, S85
Endophytic bacteria

for control of Xylella fastidiosa, S96 shaping of plant communities by, S151

Endres, G., S2.6

Engelberth, J., S49

Engelberth, M., S49

Engels, R., S208

Engler, G., 945

English, J. T., S65, S199

Eni, A. O., S49

Enterobacter cloacae

genetic diversity of environmental and clinical strains, S77

for Pythium ultimum on cucumber, 271

Entomosporium sp., on red-tip photinia, drench and foliar fungicides for control of, S68

Entz, M., S102

EnvZ/OmpR system, Erwinia amylovora virulence and, S102

EopI gene, as host specificity factor for Erwinia

amylovora, 935

Epiblema strenuana, for control of ragweed, S185

Epichloae

collection of from tall fescue, S174 ergot alkaloid gene expression studies and, S54

Epicoccum nigium, for control of Cephalanoplos setosum, $\mathrm{S} 68$

Epidemiology, networks in, 392

Epiphyas postvittana (light brown apple moth), phosphoglucose isomerase and, S70

Eradication zone, spatial sampling for detection of pathogen outside of, 725

Eremothecium coryli, on tomato and apple, brown marmorated stink bug feeding and, S22

Eretmocerus hayati, as whitefly parasitoid, S185

Ergot alkaloids

gene cluster for synthesis of in clavicipitaceous fungi, S53

in grass-endophyte association, S54

Erisyphe azaleae, on rhododendrons, S251

Erraitaimuthu, S. R., S140

Erraittaimuthu, S. R., S140

Erwinia amylovora

on apple

analysis of products evaluated for control of fire blight in the eastern United States, 512

genes regulated by $\mathrm{RcsB}$ and $\mathrm{RcsC}$ in, $\mathrm{S} 186$

Pantoea agglomerans E325 against on flower stigmas, S146, 1234

RcsC sensor kinase from, 710

streptomycin-resistant, S128

biogeographic diversity analysis of, S45

biological control of under field conditions, S60

CRISPR arrays for species diversity evaluation and microbial source tracking, S118

early detection of, S19

EnvZ/OmpR and GrrS/GrrA systems and, S102

EopI gene as host specificity factor, 935

kasugamycin for management of, 192

novel genes involved in pathogenesis of, S118

from orchards in Washington and Oregon,

plasmid content of, S26

Pantoeae spp. for control of, S232

on pear

analysis of products evaluated for control of fire blight in the eastern United States, 512

biological control of, 113, 299

genes regulated by $\mathrm{RcsB}$ and $\mathrm{RcsC}$ in, S186

RcsC sensor kinase from, 710

streptomycin-resistant, S128

quorum sensing and cyclic-di-GMP signaling systems in, S2.2

streptomycin-resistant, 182

on tobacco, type III secretion inhibitors and, S197
Erwinia carotovorum subsp. carotovorum. See

Pectobacterium carotovorum subsp. carotovorum Erwinia tracheiphila

on cantaloupe, colonization through flower inoculation, S59

on cucurbits, host specificity of, S158

Erysiphales, open access online database of, S154

Erysiphe necator

Burkhard cyclone sampler for detection of, S106

differential gene expression during conidiation in, 839

on grape

chasmothecia development and dispersal, S203

effect of acute low temperature events on, S14

effect of UV-A and UV-B on airborn conidia concentrations, S196

inoculum detection for timing of fungicide application and, S249

LAMP assays for detection of, S112

mixed reproduction modes and spatial aggregation, S20

Ren4 locus and resistance to, 502

stability of QoI resistance, S274

time lagged effects of weather variables on airborne spore concentrations, S197

visual scouting, spore trapping systems, and bioindicators for detection of, S139

volatile organic compound emission and, S174

Erysiphe spp., in ornamentals and herbs in Puerto Rice, S276

Esca-related pathogenic fungi

characterization of in grape vine plants, S21

Pythium oligandrum for control of, S21

Escherichia coli

in irrigation water, management of, S100

strain O157:H7

detection of in fresh produce, $\mathrm{S} 43$

house fly regurgitation spots as source of in leafy greens, S188

on lettuce, transcriptomic analysis, S212

persistence on plants, S212

in produce production environment, S212

Salmonella spp. and, multiplex PCR for, S77

Eshel, D., 436

Eskalen, A., S2, S49, S50, S111, S248, S249

Eskandari, F. M., S273

Esker, P., S31, S50, S191, S213, S223, 1122

Esker, P. D., 31, S241, S242, S245, 696

Esmenjaud, D., 945

Espindola, A., S41, S171

Espindola, A. S., S50

Esquivel, J. F., S119

Essential oils

for control of brown blotch disease on Agaricus bisporus, S7

for control of pinewood nematode, S137

Estevez, C., S154

Estévez de Jensen, C., S253, S276, S277, S278

Estock, M., S215

Ethylene

and host resistance against Ralstonia solanacearum on tomato, $\mathrm{S} 12$

overexpression in rice, resistance against Rhizoctonia solani and Magnaporthe oryzae and, S71

and resistance against Botrytis cinerea on apple, 1311

Ethylene-response factor 5, Tobacco mosaic virus and, S198

Etta, C. E., S131

Eucalyptus spp.

Ceratocystis fimbriata on

climate change and, S81

movement of genotypes within and among populations, 1005 
diseases of, S215

Mycosphaerella spp. on, S140

Puccinia psidii on, $\mathrm{S} 215$

Eujayl, I. A., S172

Euphorbia esula/virgata, impact of plant pathogens on post-biocontrol restoration, S24

Euphorbia yellow mosaic virus (EuYMV), in leguminous weeds, S166

European canker. See Neonectria galligena

Euschistus servus (brown stink bug), transmission

of Pantoea agglomerans on cotton and, S119

Eutypa spp., on grape, S14, S156

EuYSV. See Euphorbia yellow mosaic virus

EV-050 fungicide, as novel, broad-spectrum, and

highly potent, $\mathrm{S} 10$

Evans, H., S179

Evans, H. C., S56, S95

Evans, R. G., S98

Evans, T. A., S94, S273

Everhart, S. E., S221

Everts, K., S72

Everts, K. L., S50, S120, S204

Evolution in plant viruses, disease management and, 1136

Excreta, as source of new elixir of life, S96

Exotic pests, crisis of in international commercial trade, $\mathrm{S} 217$

Exponentials, in modeling disease epidemics, different atmospheric conditions and, 1465

Exserohilum turcicum, on corn, S148, S252

Extracellular DNA (exDNA), plant defense responses and, S40

Eyre, C. A., 1408

Fabregar, E. G., S122

Fagus sylvatica (beech)

fungal endophytic community in, abundance and diversity, $\mathrm{S} 7$

Phytophthora plurivola on, S40

Fahmeed, F., S51

Fakhoury, A., S21, S79

Fakhoury, A. M., S11, S48, S113, S153, S171

Falconi, C. E., S51

Faleiro, J. R., S3

Falk, B. W., S130

Falk, K. C., S179

Fall armyworm. See Spodoptera frugiperda

Fall webworm. See Hypantria cunea

Fallopia japonica (Japanese knotweed) Mycosphaerella spp. for control of, S56, S95 survey and screening classical biological control agents for, S179

Fallow periods, fungal and bacterial diversity in response to, $\mathrm{S} 62$

Fan, J., S34

Fan, Z., S82, S107

Fang, Q., S51

Fantino, E., S136

FAO (Food and Agriculture Organization)

IPM education in Asia and, S234

vegetable integrated pest management and farmer education in Asia and, S227

Farfan, L. C., S51

Fargione, M. J., S262

Farmer, A. D., S208

Farmer's Field School approach, in Burkina Faso, S125

Farnham, M., S189

Farzadfar, S., S62

Faske, J., S18

Faske, T. R., S267

Fassler, N., S51

Fatty acids, role in host-pathogen interactions, S230

Fayad, F., S155

Febres, V. J., S51

Fedak, G., S195

Fei, Z., S106

Feldman, E., S230

Feliciano-Rivera, M., S51
Feliziani, E., S156

Fellers, J., S208

Feltes, D., S110

Fenbuconazole, for Monilinia vaccinii-corymbosi

on blueberry, S176

Feng, C., S52

Feng, G., 620

Feng, P., S236

Feng, S., S66

Feng, T.-Y., 741

Fenpropathrin, for Panonychus citri on citrus, S186

Fereres, A., 1191

Feria, T. P., S10

Fernandes, J. C., S221

Fernández, M. B., S52

Fernandez-Aparicio, M., S239

Fernández-Muñoz, R., 119

Fernando, D. G., S52, S102

Ferrandino, F. J., S259, S260

Ferreira, G., S43

Ferreira, J. J., 757

Ferreira, M. A., 1005

Ferrisia virgata (striped mealybug), as vector of

Candidatus Liberibacter asiaticus, S73

Ferry, A. E., S52

Fescue, collection of fungal endophytes from, S174

Fichtner, E. J., 492

Ficke, A., S223

Ficus, Xanthomonas campestris on, S26

Fiedler, K., S52

Fiehn, O., S174

Fieland, V. J., S65

Field dodder. See Cuscuta campestris

Fig, Fig mosaic virus in, S97

Fig leaf mottle-associated virus (FLMaV-1), in Saudi Arabia, S5

Fig mosaic virus (FMV)

characterization and epidemiological aspects of, S97

in Saudi Arabia, S5

Figueira, A. R., S57, S200

Figueiredo, J. F., S145

Figueiredo, R. S., S52

Filho, A. C., S43

Filion, M., S9, S98, S130

Filippi, M. C., S52, S167

Fillinger, S., 1176

Finlay, K. J., S53

Finley, A., 392

Fir. See Abies spp.; Pseudotsuga menziesii

Fire ant venom alkaloids, for control of Clavi-

bacter michiganensis subsp. michiganensis on tomato, S101

Fire blight. See Erwinia amylovora

Fish, T., S63

Fish emulsion, for potato scab management and potato yield enhancement, $\mathrm{S} 1$

Fisher, T. W., S162

Fjellstrom, R., S156

Flagellin, of Candidatus Liberibacter asiaticus,

host defense response induced by, S206

Flanery, M. C., S53

Flath, K., S53

Flavonoids, grapevine leafroll disease and, S67

Fleischmann, F., S40

Fletcher, J., S7, S9, S16, S41, S43, S50, S59, S65,

S81, S135, S155, S171, S188

Flett, B. E., S18

FliD gene, Xanthomonas axonopodis and, S37

Flint, L. J., S53

FLMaV-1. See Fig leaf mottle-associated virus

Florea, S., S53, S54

Flores, F. J., S59

Floyd, C., S2.2

Floyd, C. M., S243

Fludioxonil

for control of post harvest fruit decay, S37

Typhula ishikariensis and, S17
Fluensulfone for Meloidogyne incognita on cucumber and pepper, S97 on pepper, $\mathrm{S} 131$

Fluopicolide

Phytophthora capsici strains resistant to, risk assessment of, S110

Fluopyram

for control of Sclerotium cepivorum on onion, S52

for diseases of horticultural and row crops, S54, S125

Fluorothiazole-ester, for induction of systemic acquired resistance, $\mathrm{S} 233$

Flurprimidol, and demethylation inhibitor fungicides for Sclerotinia homeocarpa on turfgrass, S25

Flutriafol, for Cercospora beticola on sugar beet, S22

Fluxapyroxad, as new broad-spectrum fungicide, S172

FMV. See Fig mosaic virus

Fonseca, M. N., S43, S152

Food security

in Africa, witchweed as challenge to, S238

climate change and, S240

EU network of excellence for, S65

importance of seed and seed systems to, S232

Foote, P., S172

Foote, T., S89

Forbes, G. A., S62, S133, S183

Forensic plant pathology

establishment of foundational Federal-academic partnership for, S16

overview of, S217

validation of rtPCR assays for, S81

Forest pathogens

associated with bark beetles infesting conifers, S204

forest products protection and, S197

historical pathways of introduction of, S137

Forest Phytophthorasi of the world website, overview of, S137

Formosa lily. See Lilium formosanum

Forrez, I., 996

Forry, B., S119

Forster, H., S2, S54, S111, S118

Förster, H., 1013

Foster, G. R., S46

Foster, J. E., S216

Fought, L., S54, S125

Fouly, H., S54

Fourie, P. H., S54

Fourier transform infrared (FTIR) spectroscopy,

for differentiation of phytopathogens, S143

Fournier, E., 1433

Fouts, D. E., S212

Fox, A., S53

Fox, A. D., 644

FRAC. See Fungicide Resistance Action Committee

Fragaria $\times$ ananassa (strawberry)

arthropod management practices and increased productivity of, S146

black root rot disease complex on, S108, S178 Botrytis cinerea on control of by volatile organic compounds of Candida intermedia, 859 forecast system for control of, S140

Colletotrichum acutatum on forecast system for control of, S140 management of, S27

Colletotrichum gloeosporioides on, S203

demonstration trialing of drip fumigants for, S129

on-farm research for implementation of methyl bromide alternatives, S45

fungal communities in roots and soils, S173

Fusarium oxysporum f. sp. fragariae on, S79

Macrophomina phaseolina on

ASI-261 for control of, S156

manipulation of resident biology for sup- 
pression of, S117

resident biology in brassicaceae seed meal amended soil, S249

methyl bromide alternatives and sting nematode management, S129

microbial ecology of fumigated vs. nontreated soils, S139

nematodes on, crop rotation for suppression of, S160

pathogens causing root and crown diseases in greenhouse, S203

Phytophthora capsici on, S43

Rhizopus stolonifer on, glucoraphane and, S128

Strawberry pallidosis associated virus in, S229

Verticillium dahliae on, S261

Fraire, S., S54

Fraisse, C. W., S140

Franc, G., S48

Francis, D. M., 1217

Francis, M. I., S55

Francki, M. G., 1278

Franco, C. C. S., 923

Frankel, S. J., S137

Frankliniella occidentalis (western flower thrips)

on tomato, influence of control programs on

Tomato spotted wilt virus incidence, S250

Tomato chlorotic spot virus and Groundnut ringspot virus on tomato and, S189

and Tomato spotted wilt virus infection,

differentially expressed proteins in response to, $\mathrm{S} 12$

Frankliniella williamsi (corn thrips), Maize chlorotic

mottle virus and, S24

Frantz, G., S189

Frare, G. F., S110

Frary, A., 154

Freakenomics, of plant protection, S213

Frederick, R. D., 535

Freeland, E., S55, S201

Freeman, A., S53

Freeman, J. H., S136

Freeman, S., S168, 828

French, B. W., S55

French, J. M., S55

French, R., S171, S2.6

French, R. D., S268

French-Monar, R. D., S163, S265, S277

FRET probe genotyping, of Xylella fastidiosa strains, S18

Frey, J., S90

Frey, J. E., S45, 105

Friskop, A., S243

Friskop, A. J., S2.2

Fritz, A. K., S18

Frog eye leaf spot disease. See Cercospora sojana

Frohning, J. R., S2.3

Fruit flies. See also Bactrocera spp., effectiveness of parasitoids for control of, S219

Fry, W., S261, S263

Fry, W. E., S25, S62

Ftayeh, R. M., 1355

Ftfl gene, and virulence of Fusarium oxysporum

f. sp. phaseoli on bean, 470

$\mathrm{Fu}, \mathrm{B} ., \mathrm{S} 102$

Fu, J., S194

Fu, Y., S83, S202, S207

$\mathrm{Fu}$, Y. Y., S55

Fuchs, A., 1471

Fuchs, M., S63, S132, 1446

Fuchs, M. F., S4, S237

Fudal, I., S230

Fuji, S., S56

Fujie, M., S2, S55

Fujimura, M., S13, S56

Fujiyoshi, P., S56, S156, S178

Fukuda, K., S3

Fukumoto navel orange. See Citrus sinensis

Fulmer, A. M., S56

Fulton, J., S123

Fumonisins
Aspergillus niger and on corn and peanut, S135 nontoxigenic strains, $\mathrm{S} 136$

in corn, reduction of by biocontrol strains of Aspergillus flavus, $\mathrm{S} 1$

Fusarium spp. on corn and, S18, S22, S206

human exposure to in Guatemala, neural tube

defects and, S222

Fung, C. H., S55

Fungaro, M. H. P., 416

Fungicide Resistance Action Committee (FRAC), overview of, S235

Fungicides

for Alternaria spp.

A. alternata on citrus, resistance to, $\mathrm{S} 182$

A. porri on onion, $\mathrm{S} 42$

A. solani: on potato, S60, S190; on tomato, S2

application of to winter wheat in absence of fungal disease, lack of economic benefit of 323

application on disease-resistant wheat, S132

for Asochyta rabiei on chickpea, detection of resistance, $\mathrm{S} 62$

azoxystrobin

for Alternaria solani on tomato, $\mathrm{S} 2$

for Cercospora sojana on soybean, resistance to, $\mathrm{S} 132$

for Cercospora zeae-maydis on corn, S31

for Rhizoctonia solani on sugar beet, S89. S245

biorational, for Monilinia spp. on peach, S97

for black root rot disease complex on strawberry, S108

for Botrytis cinerea

on apple: multiple resistance phenotypes and, S90; resistance against, 1385 on blackberry, $\mathrm{S} 151$

for Cercospora spp.

C. beticola on sugar beet, $\mathrm{S} 22$

C. kikuchii, on soybean, $\mathrm{S} 241$

C. sojina on soybean, resistance against, S267, S2.9

C. zeae-maydis on corn, S31, S242

chlorothalonil, turfgrass molds and, S17

for Colletotrichum spp. on apple

C. acutatum, $\mathrm{S} 2.5$

C. gloeosporioides, $\mathrm{S} 2.5$

for corn, previous crop history and response, S242

creeping bentgrass secondary metabolites and, S165

cucurbit powdery mildew populations, resistance and, S99

Dithane, assessment of rainfastness and efficacy of formulations, S2.6

effect of treatments on barley, S180

effect on mycophagous coccinellid, S250

for Entomosporium sp. on photinia, S68

for Erysiphe necator on grape inoculum detection for timing of application, S249

stability of resistance, $\mathrm{S} 274$

EV-050, as novel, broad-spectrum, and highly potent, $\mathrm{S} 10$

fenbuconazole, for Monilinia vaccinii-corymbosi on blueberry, S176

fenhexamid, for Botrytis cinerea on grape, S158

fludioxonil

for control of post harvest fruit decay, S37 turfgrass molds and, S17

fluensulfone, for Meloidogyne incognita on cucumber and pepper, S98

fluopicolide, Phytophthora capsici strains resistant to, S110

fluopyram for diseases of horticultural and row crops, S54

for diseases of horticultural crops, S125 fluxapyroxad, as new broad-spectrum fungicide, $\mathrm{S} 172$

foliar corn, profitability of in Illinois, S189

for Fusarium spp.

$F$. avenaceum and Rhizoctonia solani on faba bean, S30

F. graminearum: on barley, S259; on wheat, S160

F. virguliforme, on soybean, S246

for Fusicladium effusum on pecan, S11

Fusicladosporium carpophilum and Alternaria spp. on almond and, S54

for Glomerella cingulata on walnut, S99

integrated pest management in apple and, S213

IR-4 Project registration for specialty crops, S176

laboratory methods for detecting and characterizing resistance to, $\mathrm{S} 228$

for management of early blight and Septoria leaf spot in tomato, S51

meta-analysis of corn yield response to, 1122

metconazole, for Rhizoctonia solani, on sugar beet, $\mathrm{S} 118$

mixing of for delaying resistance, 1224

for Monilinia fructicola on cherry and peach, S2.6

new broad-spectrum

for brown patch and dollar spot diseases of turfgrass, powdery milder of pumpkin, and septoria leaf spot of tomato, S259

for lentil, field pea, and chickpea, S115

for pome fruits, stone fruits, fruiting vegetables, and potatoes, $\mathrm{S} 184$

for Ophisphaerella korrae on bermudagrasses, S177

for papaya postharvest diseases, S133 penthiopyrad

for Colletotrichum cereale, S261

partitioning and efficacy in apple leaves, S142

uptake and translocation in wheat leaves, S141, S142

for Phytophthora spp.

P. capsici: on pepper, S94, S115; resistance against, S79; on squash, S94

on pepper, S74, S94, S115

$P$. ramorum, zoospore germination inhibition by, $\mathrm{S} 248$

for Podosphaera xanthii

on cucurbits, S118

on pumpkin, S261

potato varieties with reduced requirements for, S15

priaxor

as new broad-spectrum for use in row crops, S51

for pome fruits, stone fruits, fruiting vegetables, and potatoes, $\mathrm{S} 184$

prochloraz, for Fusarium fujikuroi on rice, S91

propiconazole

Fusicladosporium carpophilum and Alternaria spp. on almond and, S54

for Sclerotinia homeocarpa on turfgrasses, resistance to, $\mathrm{S} 262$

turfgrass molds and, S17

Typhula ishikariensis and, S17

prothioconazole, for Cylandrocladium spp. on peanut, S19

for Puccinia spp.

P. graminis f. sp. tritici on wheat, S243

$P$. helianthi on sunflower, S243

$P$. hemerocallidis on daylily, S22

$P$. polysora on corn in Georgia, $\mathrm{S} 9$

pyraclostrobin, effect of on corn stalk health, S2.8

for Pyrenophora tritici-repentis on wheat, resistance against, $\mathrm{S} 2.7$

for Pythium spp. 
on bean, $\mathrm{S} 69$

on edamame soybean, S14

quinone outside inhibitor (QOI), for Cercospora zeae-maydis on corn, S31

resistance of Botrytis cinerea against, S56

resistance to as global issue, $\mathrm{S} 235$

for Rhizoctonia solani

on creeping bentgrass, $\mathrm{S} 41$

on soybean, post-emergence herbicides and, $\mathrm{S} 203$

for Sclerotinia spp.

S. homeocarpa on turfgrasses, S25, S79, S87, S192

S. sclerotiorum, characterization of sensitivity, S2.1

for Sclerotium cepivorum on onion, S52

SDHI, mutation range leading to resistance against, S166

sedaxane

as part of comprehensive seed care product for broad spectrum disease protection of small grains, $\mathrm{S} 165$

for Rhizoctonia solani on corn and soybean, $\mathrm{S} 132$

for seed treatment use, S133

sensitivity of Magnaporthe grisea to, S45

silicon, sorghum anthracnose and, S152

for soybean, economic analysis of, S2.1

SYP-Z048, for Monilinia fructicola, S34

triforine, for Monilinia vaccinii-corymbosi on

blueberry, S176

for turfgrass diseases, S211

for Uromyces appendiculatus on bean, S2.7

use of on soybean, economic impacts of, S15

for Venturia inaequalis, on apple, S114, S242,

S274, S2.3

Funnell-Harris, D. L., S243

Furtado, E. L., S110

Furuya, H., S56

Furuya, N., S56, S72, S95, S116, S173, S179, S188

Fusarium head blight. See Fusarium grami-

nearum; Gibberella zeae

Fusarium spp.

F. asiaticum, on wheat, nivalenol-type populations of, 124

on asparagus, $\mathrm{S} 258$

$F$. avenaceum, on faba bean, fungicide seed

treatments for, $\mathrm{S} 30$

on bean, inheritance of resistance, $\mathrm{S} 124$

F. circinatum, on Pinus radiata, $\mathrm{S} 174$

on corn

drydown rates, environmental factors, and resistance, $\mathrm{S} 251$

mycotoxins associated with in South Africa, S18

F. culmorum, on wheat in southeastern Idaho, S16

on Douglas fir, S171

empirical models for predicting epidemics of

in U.S., S170

$F$. fujikuroi, on rice

hot water treatment for seed disinfection and germination, S155

resistance to prochloraz, $\mathrm{S} 91$

$F$. graminearum

on barley: effect of fungicides on yields and deoxynivalenol levels, S259; swathing vs. straight-cut combining and, S64

cinnamic-derived acids and, 929

on corn, role of mycotoxins in seedling infection and, S22

inoculation timing, mist duration, and isolate effects on, S244

on pea, gene expression during root infection, S35

on soybean, mapping partial resistance to, S48

on wheat: climate, weather, and heterogeneity of, S221; Clonostachys rosea strain ACM941 for control of, S194; Cryptococcus flavenescens, triazole fungicides and, S160; deoxynivalenol biosynthesis-related gene expression during colonization by, 1091; molecular and phenotypic variation of German populations, S120; nivalenol-type populations of, 124; transcriptome analysis of infection by different chemotypes, S52

from koa trees, species profile and genetic variation in, S146

F. lateritium, on hazelnut, 679

F. moniliforme, on rice, silver nanoparticles for control of, S36

newly detected populations of, S57

organic sulfide fumigants for suppression of in greenhouse, S112

F. oxysporum

on Arabidopsis thaliana, volatile-mediated plant growth promotion and, S16

on Brassica rapa, Appharknessia sp. for control of, S37

f. sp. ciceris, 250

comparative genomic analysis of, S208

f. sp. cubense, on banana: comparative transcriptome analysis of, S43; control of, S89; field resistance of selected cultivars, S122; impact on export and subsistence banana production, S142; vegetative compatibility group characterization of, $\mathrm{S} 122$

f. sp. fragariae, on strawberry, S79

genome dynamics of species complex, S208

on koa tree, S165, S216

on lambs lettuce, S65

on lettuce, $\mathrm{S} 31$

f. sp. lycopersici, identification of, S142

f. sp. niveum, on watermelon, S50, S72 S159, S204

nonpathogenic, on cucumber, control of Fusarium wilt disease and, S37

F. oxysporum f. sp. vasinfectum, on cotton, S162

on peach, S197

f. sp. phaseoli, on bean, new virulence groups in, 470

f. sp. radicis-cucumerinum, on cucumber, soil suppressiveness in organic-amended soil, S91

f. sp. radicis-lycopersici: identification of, S142; on tomato, rhizobacterial induction of systemic resistance and, S65

on rocket, $\mathrm{S} 65$

on rose, $\mathrm{S} 59$

f. sp. spinaciae, on spinach, S248

on sugar beet, $\mathrm{S} 2.5$

f. sp. vasinfectum, on corn, root-knot nematode and, S270

on palms, detection in Nevada, $\mathrm{S} 125$

$F$. pseudograminearum, on wheat

fungal community analysis through ITIS sequencing, S73

QTL for resistance, S144

simple model for management of, $\mathrm{S} 12$

on snap bean and soybean, chloride salt

and changes in tap root calcium partitioning, S26

F. solani

on citrus in California, S48

Trichoderma harzianum and, S91

on sorghum

diversity and pathogenicity of, S36

effect of sorghum genotype on, S243

on soybean

association with Heterodera glycines, S42

distribution and frequency of isolation of in Iowa, S42

species complex and related mycotoxins, 960

on strawberry, S108 on sugar beet, freshly harvested and stored, 1330

on sunflower, S2.1

Trichoderma koningi genes in Materhizium anisopliae and, S33

F. tricinctum, for control of Cephalanoplos setosum, $\mathrm{S} 68$

$F$. verticillioides on corn: genetic diversity of, $\mathrm{S} 88 ; B$. mojavensis for control of, S12; movement of fungus, fumonisins, and biomarkers of exposure, S206; role of mycotoxins in seedling infection and, S22

on corn and rice, association between isolates from, $\mathrm{S} 88$

on wheat and maize in China, S82

$F$. virguliforme

on soybean: controlling with seed treatment, S124; defining interactome underlying, S153; differential gene expression and, S149; distribution and impact in Minnesota, S2.2; fungicide seed treatments for, S246; Fvfsrl gene and, S79; genes and pathways involved in development of disease, S113; interaction with soybean cyst nematodes in roots, S175; recombinant inbred line for resistance against, S87; rhizosphere microbial communities and nematodes and, S171; soybean cyst nematode and, S2.8

and soybean cyst nematode, soil suppressiveness against, 878

on wheat, isolated from sugar beet, 1338

Fusicladium effusum, on pecan

nickel and severity of, S193

phosphite for control of, S17

predictive model for, S267

QoI resistance monitoring and, S11

standard area diagrams for assessment of, S196

weather-based predictions for, $\mathrm{S} 138$

Fusicladosporium carpophilum, on almond

natural fungicide resistance and, S54

QoI-resistant populations, S111

Fuwa, H., S75

Fvfsrl gene, Fusarium virguliforme on soybean and, S79

Gabler, F., 502

Gac systems, Pseudomonas biological control strains and, S45

Gadal, L., S169

Gadkar, V. J., S9, S98, S130

Gadoury, D., S14

Gadoury, D. M., S223, 839

Gaeumannomyces graminis

on rice, mode of infection, $\mathrm{S} 202$

on wheat, S118, S201, 1481

Gagnevin, L., 887

Gai, C. S., S96

Gaitán, A. L., S7

Gajendran, G., S42, S56, S227

Galactomyces spp., molecular identification of, S118

Galagan, J., S208

Gale, L. R., S57, 124

Gale, S. W., 124

Galperin, M., S38

Galvani, C., S10

Galvez, L., S2.3

Galvez, L. C., S97

Galvino-Costa, S., S57

Galvino-Costa, S. B., S57

Gamarra, H., S57

Gamby, K., S60

Gamby, K. T., S228

Gamliel, A., S65, S92

Gandhi, K., S58, S143

Ganiger, M. C., S58

Ganoderma spp. 
for control of Xanthomonas campestris pv. vesicatoria on pepper, S154

on ironwood, S216

on oil palm, S254

Gao, D., S58

Gao, L., S58

Gao, Q., S230

Gao, X., S59, S230

Gao, Y., S58

Garbelotto, M., 1408

García, J. A., 611

García-Mariscal, K., S133

Garcia-Pedrajas, M. D., S208

García-Sánchez, M.-A., 470

García-Velasco, R., S59, S128

Garcinia mangostana (mangosteen), Pestalotiopsis sp. on, $\mathrm{S} 89$

Gardener, B. M., S231

Gardner, A., 323

Gardner, D., S2

Garibaldi, A., S65, S66

Garita, L., S255

Garland-Campbell, K., S144

Garlic. See Allium sativum

Garrett, K. A., S62, S182

Garrett, L. J., S20

Garrett, W., S126

Garrido, P., S2

Garrido, P. A., S59

Garzo, E., 1191

Garzon, C. D., S2, S9, S50, S59, S133, S183

Gaskins, V. L., S86, S141, S183

Gasore, E. R., S6

Gast, T., S84

Gaszczyk, K., S18

GATA-family transcription factors, Magnaporthe oryzae virulence and, $\mathrm{S} 2.8$

Gatch, E. W., S247, S248

Gates Foundation, seed supply challenges in sub-

Saharan Africa and, S232

Gaultheria fragrantissima, essential oil from for control of pinewood nematode, S137

Gautam, D., S59

Gautier, A., 1433

Gealy, D., S236

Gebben, S. J., S59

Gebhart, D., S23

Geddens, R. M., S141, S142

Gelineau van Waes, J., S222

Gellért, Á., S126

Geminiviruses

in chili pepper fields, S54

RNAi-mediated silencing and, S207

transcriptional regulation of complementary sense genes in, S173

whiteflies vectoring in peppers in Indonesia, S150

Genetic engineering. See also Transgenic crops risk assessment studies on safety of diseaseresistant crops, S237

visual representations of in online media, S155

Genger, R., S31

Genin, S., S168

GenomiPhi DNA amplification kit, for prepara-

tion of plant DNA, S273

Gent, D., S141

Gent, D. H., 640, 644, 805, 1112, 1366

Gent, M. P., S48

George, D., S238

Geosmithia spp.

G. morbida, on walnut complexity of population structure in US, S201

disease progress in Oregon, S146

genomic and transcriptome analysis, S201

Pityophthorus juglandis and, S138

walnut twig beetle and, S55

western oak bark beetle in oak in California and, S249

Geotrichum candidum, on tomato, post-harvest disease management, S52

Gerald, M., S59

Geraldine, A. M., S60, S109

Geraldino, P., S57

Gerami, E., S60

Geranium sp., Botrytis cinerea on, S2.4

Gerberich, K. M., S2.3

Gerbore, J., S21

Gevens, A. J., S60, S162, S246

Ghabrial, S. A., S86, S101

Ghasemi, A., S174

Gherkin. See Cucumis sativus

Ghimire, S., S74

Ghimire, S. R., S60

Ghosh, S., S85, S191

Ghoshroy, K., S98

Ghoshroy, S., S98

Giachetto, P., S43

Giampetruzzi, A., S43

Gibberella spp.

G. circinata, on pine, $\mathrm{S} 167$

G. fujikuroi, on rice, sodium hypochlorite for control of, S165

G. zeae

on barley, trichothecene profiling and population genetic analysis of, 687

chlamydospore-like structure formation by, S169

functional analysis of two acetyl coA synthetases in, S100

on wheat: biological control agents for, S200; cytological alterations induced by combinatorially selected defense peptides, S65; fungal mating pheromone peptides and, S199

Gibberellins, potato purple top phytoplasma on tomato and, S272, S275

Gibson, D., S39

Gibson, P., S124

Giesler, L., S2.8

Giesler, L. J., S2.9

Gigaspora margarita, and aphids on wheat, S2

Gigot, J. A., S248

Gilardi, G., S65

Gilbert, C., S172

Gilbertson, R., S60

Gilbertson, R. L., S13, S32, S95, S119, S137,

S210, S228, S250, 425

Gildow, F. E., S176, 627

Giles, K. L., S157

Gillett, J. M., S160

Gilley, M., S61

Gilligan, C. A., 725

Gill-Langarica, E. M., S154

Gil-Salas, F. M., 1365

Ginger. See Zingiber officinale

Ginzberg, I., 436

Giordano, P. R., S2.3

Giraldez, R., 757

Giraud, F., S47

Giroux, M. J., S25

GIS (geographic information systems), plant

disease monitoring system based on, S91

Gitaitis, R., S125, S189

Gladiolus sp., Uromyces transversalis on, S181

Glasa, M., 980

Glass, K., S162

Glassy-winged sharpshooter. See Homialodisca vitripennis

Glawe, D. A., S251

Glazebrook, J., S208

Gleason, M. L., S2.6

Glenn, A. E., S206

Global food security short courses, for enhance-

ment of urban forestry education, S38

Globodera spp. (cyst nematodes) morphological and molecular characterization of populations from Oregon and Idaho, 480

G. pallida, control and eradication of, S59

$G$. rostochiensis, on potato, deregulation of fields formerly infested with, S22

Glogoza, P., S2.6

Glomerella cingulata, on walnut, S99

Glomus intraradices, and aphids on wheat, S2

Glover, K. D., S87, S244, S2.4

GLRaV. See Grapevine leafroll associated viruses

Glucanases

from Pichia guilliermondii and Metschnikowia spp., S66

from Trichoderma harzianum, S248

Glucoraphane

Colletotrichum gloeosporioides on broccoli and, S98

Rhizopus stolonifer on strawberry and, S128

Glycine max (soybean)

Aphis glycines and, identification of common fungi infecting, S153

bean bug on, pheromone trap catches, timing of invasion and, $\mathrm{S} 48$

Bradyrhizobium japonicum on, normal nodulation, 14-3-3- protein and, S150

Cercospora spp. on

C. kikuchii: cercosporin biosynthesis and, S30, S264; effect of mineral nutrients on, S269; foliar fungicides and, S241; fungicide efficacy and timing of application, S268

C. sojina: azoxystrobin-resistant, S132; fungicide-resistant, S267; QoI-resistant populations, S2.9; survival on leaves, S203

Colletotrichum spp. on, S197, S242

Conidiobolus thromboides on, S153

cyst nematode and sudden death syndrome of, soil suppressiveness against, 870

Diaporthe spp. on

identification of accessions with resistance against, S103

D. phaseolorum, $\mathrm{S} 31, \mathrm{~S} 242$

dicamba-resistant, glyphosate-resistant weeds and, S236

discovery of new rust genes using next generation sequencing, S209

fungicide use on, economic impacts of, S15, $\mathrm{S} 2.1$

Fusarium spp. on

distribution and frequency of isolation of in Iowa, S42

Fusarium graminearum, mapping partial resistance to, $\mathrm{S} 48$

Heterodera glycines and, S42

$F$. virguliforme: controlling with seed treatment, S124; defining interactome underlying, S153; differential gene expression and, S149; distribution and impact in Minnesota, S2.2; fungicide seed treatments for, S246; Fvfsrl gene and, S79; genes and pathways involved in development of disease, S113; interaction with soybean cyst nematodes in roots, S175; recombinant inbred line for resistance against, S87; rhizosphere microbial communities and nematodes and, S171; soybean cyst nematode and, S2.8

G-protein coupled receptors in, plant defense responses and, S25

Heterodera glycines on

corn-soybean rotation systems and, S2.8

B. firmus for control of, in vitro mobility and, S161

Fusarium spp. and, S42

plant diseases associated with, S209

proteome reference map for, S126

Macrophomina phaseolina on

genes involved in phaseolinone production by, S11

qPCR detection assay for in roots, S11

Maturity Group IV, maintaining seed quality of, S5

Meloidogyne incognita on 
impact and management of, S267 potential resistance to, $\mathrm{S} 99$

meta-analysis to determine effects of disease management measures in, 31

occurrence and diagnosis of diseases of in

Korea, S100

Pandora neoaphidis on, S153

pathogens of, chloride salt and changes in tap root calcium partitioning, S26

Phakopsora spp. on

archaeophytopathology of, S244

$P$. pachyrhizi: aerial application for control of, S8; extended latent infection period with, S269; identification of resistance genes in Hyuuga soybean, 535; near isogenic lines, resistance and, S58; neural networks for pattern recognition in, $\mathrm{S} 123$ penetration and establishment of, 894 silicon amendment and resistance to, S257 virus-induced gene silencing and, S139

Phomopsis spp. on

identification of accessions with resistance against, S103

stink bugs and, S85

widespread latent and pathogenic infection in Minnesota, S243

Phytophthora sojae on

avrla gene and, S246

comparison of genes underlying two QTL conferring partial resistance to, S186 mapping QTL conferring resistance to, S186

new race of in Argentina, S64

QTL conferring partial resistance, $\mathrm{S} 100$

Rps gene loci and, S66

Pythium spp. on

$P$. aphanidermatum on, seed exudates and resistance to, $\mathrm{S} 11$

effect of fungicide seed treatments on, S14

$P$. irregulare on, mapping partial resistance to, S48

P. ultimum on, Reynoutria sp. for control of, S172

Rhizoctonia solani on

Heterodera glycines and, S157, S2.3

post-emergence herbicides, strobulurin fungicides and, S203

Reynoutria sp. for control of, S172

sedaxane for control of, S132

RNAi-based resistance to mixed viral infec-

tions in, 1264

Rotylenchulus reniformis on, potential resistance to, S99

Sclerotinia sclerotiorum on

Coniothyrium minitans for control of, S126, S245

mycoparasites of, S2.4

sclerotial viability and, S83

spatial characterization of favoral climate conditions for rust on, S155

susceptibility of to single and multiple viral infections in Nigeria, S78

Thielaviopsis basicola on

effect of seed treatments on, S27

as emerging problem in Arkansas, S38

University of Arkansas disease screening project for, S48

Xanthomonas axonopodis on, virulence factors involved in, S32

Glynn, J. M., S105

Glynn, N. C., S61

Glyphosate

deposit structure, biological efficacy and, S13

impacts on plant disease and plant health and yield, S93

managing weeds resistant to in soybean, S236

non-target effects on apples, S262

for Rhizoctonia solani on sugar beet, negative interactions with azoxystrobin, S126

Gmitter, F. G., S51
Goates, B. J., S127

Gödecke, R., 1338

Godonou, I., S224

Godsey, C., S40

Godsey, C. B., S265

Goenaga, R., S277

Goenaga, R. J., S163

Goesmann, A., S19, S144

Goharzad, F., S122

Gokte-Narkhedkar, N., S61

Gold, S., S84

Gold, S. E., S208

Goldberg, N., S55

Goldberger, E., S163

Goldwasser, Y., S239

Golino, D., S134

Golino, D. A., S61, S62

Golnaraghi, A., S62

Golod, J., S161

Golovinomyces sp., on acalifa, S253

Golzar, H., 1278

Gomes de Oliveira, H., S254

Gomez-Alpizar, L., S153

Gomez-Montano, L., S62

Gonsalves, D., S237

Gonzales, M. A., S62

Gonzalez, A., S111, S172

Gonzalez, M. F., S120

González-Díaz, J. G., S59

Gonzalez-Franco, A. C., S154

Goo, H., S74

Goodwin, P. H., S182, S211

Goodwin, S., S243

Goodwin, S. B., S208, 1251

Gooseberry vein banding associated virus

(GVBaV), in Ribes spp., S194

Gopalakrishnan, S., S62

Gordon, T., S109

Gordon, T. R., S79, S152, S167, S174

Gore, J., S5, S85

Gorris, M. T., 611

Gorsoy, G., S24

Goss, E. M., S62, S65, 166

Gossen, B., S30

Gossen, B. D., S77, 1424

Gossypium spp. (cotton)

Cotton leaf curl virus in, isolate diversity, breakdown of resistance and, S30

Fusarium oxysporum f. sp. vasinfectum on, S162

Meloidogyne incognita on engineering resistance by RNAi mediated silencing of parasitism genes of, S61 field morphology and, S111

QTL analysis for transgressive resistance, S187

Thielaviopsis basicola and, S209

nematodes on

host resistance, S265

management of in multiple soil types with Telone II, S266

Pantoea agglomerans on, transmission by brown stink bug, S119

Pythium ultimum on, Reynoutria sp. for control of, S172

reniform nematode on, B. firmus strain GB126 for control of, S29

Rhizoctonia solani on, Reynoutria sp. for control of, S172

Rotylenchulus reniformis on, soil moisture content and, S123

seaweed for suppression of root diseases of, S8

Thielaviopsis basicola on, S111, S209

virus-induced gene silencing for assessing gene function in, $\mathrm{S} 21$

Goswami, R., S245, S2.7

Goswami, R. S., S35, S62, S138, S242, S2.5

Gothandapani, S., S164

Goto, T., S188
Gottula, J., S63

Gottwald, T., S213

Gottwald, T. R., S17, 1184

Gougherty, A., S63, S222, S2.3

Govaerts, B., S226

Govindarajulu, M., S150

Gowda, S., S68, S81, S206

Goyer, C., S9

G-protein coupled receptors, in soybean, plant defense responses and, $\mathrm{S} 25$

Grabau, E. A., 786

Grabherr, M., S208

Grabowski, M., S48

Grabowski, M. A., S63

Graça, R. N., S215

Grafting

Cherry leafroll virus in walnut and, S111

for control of Ralstonia solanacearum on tomato, S136

for management of Verticillium dahliae on tomato, S79

Graham, J. H., S17, S55, S84

Graham, M. A., S139

Grand-Duchy of Luxembourg, fungal diseases of winter wheat in, S47

Granke, L., S63, S149

Granke, L. L., 1061

Grant, J. A., S179

Grant, S. J., S251

Grape. See Vitis spp.

Grapefruit. See Citrus paradisi

Grapevine fanleaf virus (GFLV) engineering into plant expression vector, S63 virus-derived constraints for resistance against, $\mathrm{S} 132$

Grapevine leafroll-associated viruses (GLRaV)

Grapevine leafroll-associated virus 1

as genetically diverse population in wine grape cultivars, $\mathrm{S} 4$

in grape, as genetically diverse population, 1446

Grapevine leafroll-associated virus 3

5 ' nontranslated region and replication of, S8

foliar insecticidal treatments for, S85

on grape, genetic diversity in $3^{\prime}$ terminal region of, 445

impacts of on wine grape cultivar, S4

Grapevine leafroll-associated virus 7, detection of, $\mathrm{S} 4$

effect of seasonal changes on titer and distribution in vine, $\mathrm{S} 134$

effects of on anthocyanins and flavonoids, S67

hosts as reservoirs for spread of, S61

overview of, S229

proposed guidelines for sample processing and

downstream detection of, S134

rapid and real-time detection of, $\mathrm{S} 144$

Grapevine vein clearing virus (GVCV)

genome sequence of, S202

in grape, 1081

Grasses, USDA-APHIS quarantine program for, S114

Grau, C. R., S241

Gray, S., S63, S64

Gray, S. M., S88, 778, 1052

Gray leaf spot (GLS). See Cercospora zeaemaydis; Magnaporthe grisea

Green leaf volatiles, of corn, as plant defense mechanism, S48

Green manure. See Cover crops

Green Muscle, for control of hopper bands of

locusts and sahelian grasshoppers, S224

Greenwald, C. J., S64

Greenwald, J. W., S64

Greer, A. M., S38

Greer, C. A., 85

Greer, G., S87

Gregoire, T., S2.6

Gregory, N. F., S273 
Gregory, S., S222

Griffin, T. S., 135

Griffiths, W., S53

Grigoras, I., S64

Grigoriev, I. V., S208

Grijalba, P. E., S64, S136

Grisham, M. P., S64

Grizard, D., S21

Gronenborn, B., S64

Grosmannia clavigera, on pine, S188

Gross, D., 1285

Gross, D. C., S64

Gross, N. W., S65, S199

Gross, P., S64

Gross, T., S21

Grosser, J. W., S55

Groth, D. E., S166, S266

Groundnut ringspot virus (GRSV), on tomato, S189

Groundnuts, biological control of root rots of, S164

Grove, G., S112, S196, S197

Grove, G. G., S106, S203, S249

Groves, R., S31

Groves, R. L., S130

GrrS/GrrA system, Erwinia amylovora virulence and, $\mathrm{S} 102$

GRSV. See Groundnut ringspot virus

Grubisha, L., S250

Grünig, C. R., S151

Grunwald, N. J., S62, S65

Grünwald, N. J., 166, 805

Grybauskas, A., 1122

Gu, B., S230

Gu, D., S116

Gu, G., S33

Guasco, J., 182

Guazuma ulmifolia (guacime), phytoplasma causing witches' broom in, S255

Gubler, D., S14

Gubler, W. D., S39, S139, S174, S179, S250

Gudmestad, N., S241, S2.1

Gudmestad, N. C., S4, S190, S2.7

Guenthner, J., S31

Guérin, F., 887

Guérin-Dubrana, L., S21

Guerrero, J., S173

Guevara, J., S151

Guevara, M. G., S52

Gugino, B. K., S1, S65, S274

Guha Roy, S., S261

Guignardia spp.

G. bidwelli, on grape, S169

G. citricarpa, on citrus detection of, S76

pseudothecium maturation and ascospore dispersal, S54

identification of pathogenic vs. nonpathogenic, S255

Guilhabert, M., S184

Guiltinan, M. J., S272

Guimarães, T. G., S174

Gül, A., S65

Gullino, M., S65, S66, S216

Gulya, T., S115, 241, S241, S243, S2.1, S2.2

Gulya, T. J., S4, S2.3

Gunadi, A., S66

Gunasekaran, D., S94

Gundersen, B., S79

Guo, B., S66

Guo, J., S129, S185

Guo, J.-H., 1202, 1481

Guo, L., S148, S175

Guo, M., S58

Guo, Q., S111

Guo, Y., S67

Guo, Z., S108

Guo, Z. K., 377

Gupta, V., S243

Gurr, G. M., S151
Gurung, S., S127, S243, 1251, 1301

Gutha, L. R., S4, S67

Gutierrez, A., S240

Gutiérrez-Gutiérrez, C., 1168

Gutteridge, R. J., S118

Gutting, H., S149

Guzmán-González, S., S133

GVBaV. See Gooseberry vein banding associated virus

GVCV (Grapevine vein clearing virus). See

Grapevine vein clearing virus

Gwinn, K. D., S2, S75, S109, S184

Gyawali, S., S67, 687

Gymnoascus reessii za-130, extraction of active component from, S107

Ha, B.-K., 535

Ha, Y., S67

Haag, P., S180

Haas, M. W., S57

Hackett, W. P., S92

Hadi, B., S67

Hadwiger, L. A., S68

Hagan, A. K., S68

Hahn, M., 1176

Haixia, Z., S68

Hajeri, S., S68, S69

Hajmansoor, S., S60, S88, S112, S142

Hakuno, F., S147

Halbrendt, N., S80

Hall, C., 654

Hall, D., S73

Hall, D. G., S6

Halleen, F., S14

Hallen-Adams, H. E., 1091

Hallett, S. G., S134

Halley, S., S243, S245, S2.7

Halley, S. A., S200

Halloran, J., S98

Halloran, J. M., 135

Haloxyfop-methyl, adjuvants, rain-free period and, S8

Halterman, D., S69

Halterman, D. A., 263

Halyomorpha halys (brown marmorated stink

bug), Eremothecium coryli on apple and, S22

Ham, J., S264, S266, S267, S268

Ham, J. H., S88, S166, S266

Hamada, N. A., S155

Hamadoun, A., S130

Hambleton, S., S157

Hamelin, R., S51

Hamid, S., S192

Hamilton, J., S168

Hamilton, J. P., S247

Hammerschmidt, R., S188

Hammig, M., S227

Hammig, M. D., S226

Hammond, J., S126, S181

Hammond, R., S275

Hammond, R. W., S126, S151, S273, 1136

Hammond-Kosack, K. E., S118

Hampton, J. G., S178

Han, C., S32, S163, S205

Han, D., S207

Han, E., S74

Han, J., S97

Han, S., S100, S137, S141

Hanai, L. R., 416

Hand, E. K., S139

Handoo, Z. A., 480

Hanif, Z., S238

Hanlon, R., S230

Hanna, J. W., S92

Hanna, L. T., S157

Hansen, E. M., S137

Hansen, J. M., 1301

Hanseniaspora uvarum, on grape, S259

Hanson, S., S55, S98

Hanson, S. L., S24
Hao, J., S119, S156, S244

Hao, J. J., S110, 1104

Hao, W., S69

Harano, K., S177

Harbertson, J., S4

Harbertson, J. F., S67

Harchenko, W. A., S2.5

Harding, M. W., S69

Hardingham, J., S215

Harker, K. N., S180

Harmon, C. L., S183

Harmon, P., S39, S199

Harmon, P. F., S87, S104, S115, S182

Harper, D., S94

Harrington, M., S67

Harrington, T. C., S217, 555, 1005

Harris, D. K., 535

Harrison, L., S259

Harrison, L. A., S69

Harrison, R., S90

Harrison, S. A., 124

Harshman, J. M., S69

Hartl, L., 1209

Hartman, G. L., S61, S157, S197, S203, S244, S246, 750

Hartney, S. L., S70

Hartung, J., S199, S279

Hartung, J. S., S70, S96, S156

Harveson, R., S70, S159

Harveson, R. M., S2.3, S2.7

Harwood, T., 392

Hasanzadeh, N., S7, S163, S174

Hashemi, M., S169

Hashimoto, M., 567

Hashimoto, Y., S116

Hasiow-Jaroszewska, B., S18, S70

Hassan, G., S238

Hassan, K., S117

Hassan, K. A., S231

Hassan, M., S70, S97

Hassanzadeh, N., S60

Haudenshield, J. S., S61, S244, S246

Hausbeck, M., S63, S110, S149

Hausbeck, M. K., 1061

Haustoria, Puccinia striiformis f. sp. tritici effector highly expressed in, S198

Hauxwell, C., S224

Havens, W. M., S101

Hawaii, overview of alien pest problem in, S217

Hawes, M. C., S40

Hay, F. S., S141, S162, 1112

Hayes, R., S46, S59

Hayes, R. J., S208

Haygood, R. A., S266

Hayslett, M., S70

Hazelnut. See Corylus avellana

He, H., S186

He, S., S70

He, Z., S21, S98, 135, S156, S178, S277

He, Z. L., 1097

Heckert, S., S71

Heeb, S., S93

Hegedus, D. D., S67

Heiman, D. I., S208

Hein, G. L., S24, S71, S234, S2.2, S2.6

Heitholt, J., S268

Heitkamp, E., S115

Held, B., S78

Helder, H., S90

Helianthemum spp., identification, hosts, distribution, and molecular phylogeny of, S81

Helianthus annuus (sunflower)

Fusarium spp. on, S2.1

Phomopsis spp. on, S115

Plasmopara halstedii on characterization of two types of resistance to, 970

emergence of new virulent strains, S2.3

Puccinia helianthi on fungicides for management of, S243 
hybrid susceptibility and impact on yield, S2.2

identification of resistance to, 241

timing trial in Nebraska 2010, S2.7

Verticillium dahliae on, presumptive vegetative compatibility groups of, S4, S241

Helicoverpa spp.

biological control of, $\mathrm{S} 224$

injection of insecticides in silk channels for management of, S169

Helliwell, E. E., S71

Helminthospoirum spp.

H. oryzae, on rice, Pseudomonas fluorescens

SP007s for control of, S146

H. solani, on potato

natural plant volatile compounds for control of, S193

Pseudomonas strains antagonistic to, S257

Hemerocallis spp. (daylily), Puccinia hemerocallidis on, management of, S22

Hemolysin, of Candidatus Liberibacter asiaticus, expression in citrus using citrus tristeza virus vector, S68

Hempfling, J. W., S259

Hemsanit, N., S146

Henbit. See Lamium amplexicaule

Henderson, L., S63

Hendrickson, P., S243, S245, S2.2, S2.7

Henkels, M. D., S172

Henkes, M., S85

Henne, D. C., S194

Henriquez, J. L., S71

Henrissat, B., S208

Henry, C., S65

Heracleum mantegassium, as invasive weed, S238

Herai, R., S43

Herbicide Resistance Action Committee (HRAC), overview of, S236

Herbicides

ALS inhibiting, current state of resistance to, $\mathrm{S} 236$

cesA3 mutations, Phytophthora capsici resistance and, S34

dicamba, soybean and glyphosate-resistant weeds, S236

gene flow and resistance, $\mathrm{S} 236$

glyphosphate, deposit structure, biological efficacy and, S13

haloxyfop-methyl, adjuvants, rain-free period and, $\mathrm{S} 8$

impact of on weed fluorescent spectra and lifetimes, S77

maximum residue limits and, S235

resistance to as global issue, $\mathrm{S} 236$

resistance to as threat to dryland farming in Mediterranean, S236

for Rhizoctonia solani on soybean, strobulurin fungicides and, S203

seed treatments for control of witchweed in sorghum and, S232

Herman, M., S62

Hermanto, C., S122

Hernamdez, A. G., S106

Hernandez, E., S151

Hernandez-Huerta, J., S154

Hernandez-Zepeda, C., S20, S21

Herrera, C., S136

Herrera, D., S250

Hershenhorn, J., 213

Hert, A., S94

Herve, C., S71

Hessel, D. A., S2.4

Heterodera $\mathrm{spp}$

distribution and sequence analysis of rDNAITS region of, $\mathrm{S} 189$

$H$. filipjevi (cereal cyst nematode), on wheat, S196

H. glycines (soybean cyst nematode)

Fusarium virguliforme on soybean and, S42, S175, S2.8 on henbit, S2.9

population density, soil $\mathrm{pH}$ and, S191

on soybean: association with Fusarium spp., S42; corn-soybean rotation systems and, S2.8; plant diseases associated with, S209; proteome reference map for, S126; Rhizoctonia solani and, S157, S2.3; spatial distribution in research plots, S144; in vitro mobility and, S161

and sudden death syndrome, soil suppressiveness against, 878

H. schachtii (beet cyst nematode), on sugarcane, NMR for belowground imaging of, S72 on wheat, species and pathotype identification, S102

Heterothallism, in Didymellaceae, S2.2

Heungens, K., 166

Hickory, bitternut. See Carya cordiformis

Hickory bark beetle. See Scolytus quadrispinosus

Hidayat, S. H., S143

Hidayati, N., S186

Higashi, C. H., S72

Higgins, E., S67

Higgins, R., S278, S2.7

High plains virus (HPV)

sensitive detection and discrimination of, S9

in wheat, transmission of by wheat curl mite, S71

Higuchi, K., S95

Hikishima, M., S60

Hilf , M. E., 1242

Hill, J. H., S139

Hillman, B. I., S25, S138, S231

Hillnhütter, C., S72

Himeno, M., 567

Himmel, P., S172

Himmelstein, J., S72

Hinton, D. M., S12, S135

Hipkins, P., S228

Hippeastrum vittatum, topsoviruses infecting in

Kunming, China, S51

Hiromasa, Y., S12

Hirsch, M., S72

Hirsch, R. L., S72

HLB. See Candidatus Liberibacter asiaticus

Ho, F., S186

Ho, M., S37

Hoang, H., S72, S116, S188

Hobbelen, P. H. F., 1224

Hobbs, H. A., 750

Hobbs, S. L., S73

Hoch, H. C., S10

Hodges, A. C., S45, S73

Hodson, D., S220

Hodzic, E., S134

Hoenisch, R. W., S73

Hoepting, C. A., S65

Hoeschle-Zeledon, I., S225

Hoffman, M. T., S73

Hoffman, W., S73

Hoffmann, L., S47

Hoffstetter, A. L., S2.4

Höfte, M., 996

Hogg, A. C., S73

Holb, I. J., S221

Holbrook, C., S66

Holczer-Erlich, O., 436

Holdcroft, A. M., S73

Holden, D., S126

Holdenrieder, O., 392

Holguin, O., S104

Hollaway, G., S53

Hollier, C. A., S223, S266

Holloway, C., S68

Holmes, G., S131

Holmes, G. J., 451

Holmquist, K., 205

Holterman, M., S90

Homalodisca vitripennis reovirus (HoVRV), in glassy-winged sharpshooter, S171
Homialodisca vitripennis (glassy-winged sharpshooter)

Homalodisca vitripennis reovirus in, S171

volatile organic compounds produced by grape hosts infested with, S184

Honeycutt, C. W., 135

Honeycutt, E., S48

Honeycutt, W., S98

Hong, C., S69, S74, S93

Hong, J. C., S74

Hong, L., S148

Hong, S., S36, S74

Honorato Junior, J., S75

Hood, I. A., 583

Hop stunt viroid (HSVd), in stone fruit trees, detection of, $\mathrm{S} 105$

Hopkins, A., S174

Hoplolaimus spp., on corn, comparison of methods for extracting, S2.1

Hora-Junior, B. T., S166

Hordeum vulgare (barley), S161

Blumeria graminis on, host and nonhost resistances and, S202

Cochliobolus sativus on, S5, S259

effect of addition of chromosome of to wheat with gall-inducing leafhopper, S94

Fusarium graminearum on effect of fungicides on yields and deoxynivalenol levels, S259 swathing vs. straight-cut combining and, S64

impact of fungicide and herbicide treatments on, S180

Puccinia graminis on, rpg4 and rpg5 genes and resistance against, $\mathrm{S} 21$

Pyrenophora teres on detection in conidia and seed, S98

ELISA for detection of, S24

Laetisaria arvalis for biological control of, S98

Ustilago nuda on, rapid detection of, $\mathrm{S} 10$

Horita, M., S75, S173

Horn, B., S1

Horner, K., S67

Horobet, P., S75

Horsenettle. See Solanum carolinense

Horvath, B. J., S165

Horvath, D., S237

Hosseini, P., S209

Hosseinikhah Choshali, A., S75

Host environment, benefits and pitfalls of changing for purpose of plant protection, S240

Host feeding, in white fly parasitoids, S185

Host resistance

against Agrobacterium tumefaciens on walnut, S91

artificial miRNAs for engineering resistance against tospoviruses, $\mathrm{S} 121$

against Aspergillus spp. in, proteins associated with, S21

against Beet necrotic yellow vein virus, 718

against Blumeria graminis, S202

against Botrytis cinerea

on Formosa lily, Bacillus cereus and, S76 grapevine-associated bacteria that induce a prime oxidative burst and phytoalexin production and, 768

molecular and biochemical characterization of in solanaceae, $\mathrm{S} 167$

against Candidatus Liberibacter asiaticus, flagellin protein and, S206

against Cephalosporium spp., in wheat, S18

against Clavibacter michiganensis subsp. michiganensis, silencing of basal defense response-related gene expression and, 349

against Colletotrichum lindemuthianum, genetic analysis of, 757

against Cotton leaf curl virus, isolate diversity and breakdown of, S30

against Cronartium ribicola, white pine 
chitinase genes and, 904

against Cucumber mosaic virus, on soybean, 575

against Curvularia lunata on corn, S33, S147

against Erysiphe necator, on grape, Ren4

locus and, 502

against Fusarium spp.

on bean, inheritance of, $\mathrm{S} 124$

$F$. graminearum, on soybean, $\mathrm{S} 48$

F. oxysporum: on banana, S122; on chick-

pea, 250; on tomato, rhizobacteria and, S65

F. virguliforme on soybean, $\mathrm{S} 87$

Fusicladium effusum on pecan and, S17

G-protein coupled receptors in soybean and, S25

hypersensitive response and, in Arabidopsis thaliana, 741

hypovirulent Rhizoctonia spp. and, S168, 828 against Iris yellow spot virus in onion, S17 against Magnaporthe oryzae on rice, S71, S82, S156, 176, 620

against Meloidogyne spp.

M. incognita: on cotton, S265; on Prunus

spp., Ma gene and, 945; on soybean, S99

$M i$ resistance gene and, 410

oligoadenylate synthase pathway and, S2.3

against Pectobacterium carotovorum subsp. carotovorum, on wild potato, 205

against Phakopsora pachyrhizi, on soybean,

S58, S139, S257, 535

against Phelipanche and Orobanche spp. and

on tomato, strigolactone and, 213 against Phytophthora spp.

$P$. capsici, on watermelon, S94

P. infestans: Rpi-blb1 gene and, S69; on wild potato, $R B$ gene and, 263

$P$. nicotianae on tobacco, $\mathrm{S} 98$

$P$. palmivora on papaya, $\mathrm{S} 82$

P. sojae, on soybean, S66, S100, S186

against Plasmodiophora brassicae on canola, management of, S77

against Plasmopara halstedii, on sunflower,

characterization of two types of, 970

against Potato virus $X$, NbSL11P protein and, S36

against Potato virus $Y$

eIF4E genes and, S64

$R$ genes, breeding programs and, $\mathrm{S} 190$

test of taxonomic and biogeographic predictivity, 1074

in tobacco, overcoming during single-host passages, S194

against Pseudomonas spp.

$P$. aeruginosa on oil palm, $\mathrm{S} 192$

P. cannabina pv. alisalensis on Brassica spp., S189

P. syringae, on wheat, $\mathrm{S} 2.4$

against Puccinia spp.

P. graminis f. sp. tritici race TTKSK: on Triticum monococcum, 1418; on wheat S127, S132

P. graminis on barley, rpg4 and rpg5 genes and, S21

$P$. helianthi, on sunflower, 241

$P$. striiformis on wheat, S26, S147, S205

on wheat, novel resistance, $\mathrm{S} 25$

against Pyrenophora tritici-repentis on wheat, S2.7

against Pythium spp.

$P$. aphanidermatum on soybean, seed exudates and, S11

$P$. irregulare on soybean, $\mathrm{S} 48$

$P$. ultimum on potato, screening for resistance, S190

against Ralstonia solanacearum

species complex, on tomato, pepper, and eggplant, 154

on tobacco, Pseudomonas spp. and, S72

on tomato: salicylic acid, ethylene path- ways, S121; SSR linkers linked to QTL associated with, S186

against Rhizoctonia spp.

by Brachiaria spp., S6

$R$. solani, on rice, S71, S97, S170

against rice diseases, $\mathrm{S} 204$

RNAi-based in plants expressing short

hairpins, 1264

against Rotylenchulus reniformis

on cotton, S265

on soybean, $\mathrm{S} 99$

SABP2-mediated, effect of pesticide treatments on, $\mathrm{S} 94$

against Sclerotinia spp.

S. minor, on peanut, 786

S. sclerotiorum: on annual bedding plants,

S63; on Brassica napus, S67; on peanut, S168

against sheath blight disease, rice chitinase genes and, S100

against Sirococcus clavigigenti-juglandacearum on butternut, S262

against Soilborne wheat mosaic virus in wheat, 1322

against Stagonospora nodorum on wheat, 1278

against Striga spp. on sorghum, S101

against Tobacco mosaic virus, ethyleneresponse factor 5 and, S198

against Tomato spotted wilt virus evolution of resistance-breaking and, S75 in lettuce, $\mathrm{S} 3$

Uromyces appendiculatus on bean, identification of multiple genes for, S138

against Venturia inaequalis on apple, Vf gene and, S14

against Xanthomonas spp

X. axonopodis on cassava, S152

X. citri: on kumquat, S51; XAC1496 gene and, S75

Hotchkiss, M. W., S17, S193

Hou, X., S102

Hou, Y., S103

Houle, J., S75

House flies, regurgitation of as source of $E$. coli

O157:H7 on leafy greens, S188

HoVRV. See Homalodisca vitripennis reovirus

Howard, R. J., S69

Howe, G., S230

Howe, K., S63

Howell, B., S195

Hoying, S. A., S27

Hoyos, G., S215

HPV. See High plains virus

HR. See Hypersensitive response

Hsiang, T., S211

Hsieh, J., S109

Hsp-alpha protein, movement of Bean dwarf mosaic virus in tobacco and, S137

Hsu, S., S31, S41

Hsu, Y., S150

HSVd. See Hop stunt viroid

$\mathrm{Hu}, \mathrm{D} ., \mathrm{S} 103$

Hu, J., S42, S74, S76, S119, S204, 786

$\mathrm{Hu}$, J. S., S229

$\mathrm{Hu}$, M., S76

Hu, M. X., 1270

Hu, X., S57, S75, S88, 778, 1052

Hua, G. K. H., 996

Huan, J., S202

Huang, C., S76, S173

Huang, H., S34, 620

Huang, H. C., 859

Huang, H.-E., 741

Huang, J., S31, S140, S202

Huang, K., S76, S239, S273

Huang, L., S25, S251, 620

Huang, Q., S77

Huang, R., 859

Huang, S., S186
Huang, T., S41, S76, S180

Huang, W., S76, S180

Huang, Y., S139

Huanglongbing (HLB). See Candidatus Liberibacter asiaticus

Huber, C., S259

Huber, D. M., S77, S240

Huber, S. C., S150

Hudler, G. W., S213

Huettel, R. N., 52, 819

Hughes, G., 654

Hughes, J., S49

Hui, W., S148

Huifang, S., S15

Hulbert, S., S198, S208

Huleihal, M., S143

Hulke, B. S., 241

Humann, J., S68

Humann, J. L., S77

Humayun, P., S62

Hummel, N. A., S73

Hunger, R. L., S157

Hunger, R. M., S2, S20, S132, 1322

Hunsberger, L. K., S118, S261

Hunsche, M., S13, S22, S77

Hur, J., S77

Huryn, K. L., 85

Husebye, D., S182

Hutton, S. F., 1217

Hwang, B., S76

Hwang, J., S131

Hwang, S., S30, S77

Hyakumachi, M., S165

Hydrangea sp., Corynespora cassiicola and Cercospora sp. on, $\mathrm{S} 121$

Hydrogen peroxide, molecular targets of in fungal pathogen mitochondria under oxidative stress, S176

Hymenocallis littoralis, topsoviruses infecting in

Kunming, China, S51

Hypantria cunea, Bacillus thuringiensis var. kurstaki for control of, S177

Hyparrhenia rufa, fungi for biological control of, S278

Hypersensitive response (HR)

Agrobacterium vitis on tobacco and, S23

in Arabidopsis thaliana, C-terminal region of plant ferredoxin-like protein and, 741

Phytophthora sojae on soybean and, S66

PopW and control of Tobacco mosaic virus, 1202

in sunflower, Plasmopara halstedii and, 970

Xanthomonas perforans on tomato and, 1217

Hyperspectral remote sensing, for powdery mildew on wheat, S26

Hypothenemus hampei (coffee berry borer) Bacillus spp. for control of, S278 management of, $\mathrm{S} 124$

Hypovirulence, Rhizoctonia spp. and, 828

Hypoviruses, virulence of Cryphonectria parasitica on chestnut and, S170

Hyptis suaveolens, biological control activity of essential oil from, S132

HYR1, Magnaporthe oryzae on rice and, S76, $\mathrm{S} 273$

Hyten, D. L., 535

IAA. See Indole-3-acetic acid

Ibikunle, O., S232

Ichinose, Y., S165

ICRISAT mini-core peanut germplasm, Sclerotinia minor resistance, oleic acid composition and, S30

Identification Technology Program, overview of, S218

Ignatov, A. N., S78

Ikeda, K., S13

Imai, R., S239

Imazalil, for control of Colletotrichum gloeosporioides on avocado, S128 
Imbor, M., S78

Impatiens necrotic spot virus (INSV), functional analysis of, S95

Impatiens sp., Pythium cryptoirregulare on, S258

Import regulations. See also Quarantine

managing pest risk of plants for planting in international trade, S114

maximum residue limits and, S235

In silico simulation of massively parallel sequencing, as diagnostic tool, S41

In vitro therapy, for elimination of small fruit viruses, $\mathrm{S} 81$

Inagaki, Y., S165

Inc-1 plasmid, of Xylella fastidiosa, S99

Inch, S., S78

Inch, S. A., S78

Inderbitzin, P., S35, S78, S208

Indole-3-acetic acid (IAA), and Streptomyces scabie $i$ in radish, 1045

Indra, J., S162

Induced systemic resistance (ISR)

Bacillus vallismortis and, S234

biological control agents for potato and, S30

from evolutionary perspective, S152

against Fusarium oxysporum f. sp. radicis-lycopersici on tomato, rhizobacteria and, S65

hypovirulent Rhizoctonia spp. and, 828

improved resistance against Botrytis cinerea and, 768

Rhizobacteria spp., and Magnaporthe oryzae on rice, $\mathrm{S} 5$

Industry Pest Information Platform (iPIPE), progress report on, S46

Ingelbrecht, I., S6

Ingham, R. E., 480

Inglis, D., S78, S79, S259

Inglis, D. A., S247

Inguagiato, J., S87

Inguagiato, J. C., S79

Innes, L., S260

Inoculation methods, for evaluating root pathogens of wheat, S246

Insecticide Resistance Action Committee (IRAC), overview of, S235

Insecticides

maximum residue limits and, S235

neonicotinoid

development of in China, S233

recent developments in, $\mathrm{S} 233$

nitromethylene nicotinoids, metabolism and stability of, S194

resistance to as global issue, $\mathrm{S} 235$

INSV. See Impatiens necrotic spot virus

Integrated pest management (IPM)

in Bangladesh, S227

biological control of arthropod pests in Indonesia and, S224

bioprotection strategy for greater integration of beneficial microbes into, S223

in Central Asia, S226

Cercospora beticola on sugar beet and, S22 for coconut rhinoceros beetle, S219, S220

for control of Fusarium graminearum on wheat, Cryptococcus flavenescens, triazole fungicides and, S160

and decision support systems, perceptions of risk, risk aversion, and barriers to adoption of, 640

education about, S234

FAO and farmer education in Asia and, S227

fungicide resistance in apple management and, S213

in India, S226, S227

international perspectives on education in for advancing sustainable agriculture systems, S234

in Latin America and Caribbean, S227

legumes and, S161

of mealybugs on brinjal, S162

onion and, S56, S161 opportunities for graduates of in international agriculture, $\mathrm{S} 228$

in Philippines, S227

plant growth promoting rhizobacteria for tropical vegetables in South India, S159

for potato

in developing countries, S226

in Maine, S47

in Tibetan Plateau, S33

for tomatoes in West Africa, S60

in tropics and Uganda, S228

for vegetable crops, microbial control in, S225

virus diseases of vegetable production in south

and southeast Asia and, S143

in West Africa, S228

for wheat in Oklahoma, S157

Internal transcribed spacer (ITS) analysis

for Fusarium pseudograminearum on wheat, S73

for genetic relatedness of Pseudoperonospora spp., 805

Inukai, T., 575

Invasive species, community-based education and, S45

Inverse power laws

in modeling disease epidemics, different atmospheric conditions and, 1465

Ionescu, M., S32, S178

Iott, M., S79

$i$ PhyClassifier, for phytoplasma identification and classification, S214

IPM. See Integrated pest management

Ipomoea batatas (sweet potato)

Bemisia tabaci on, S201

Macrophomina phaseolina on, S138

potyviruses in, S270

Sweet potato viruses in

detection of by one-step RT-PCR, S102

insect vector movement and, S270

phylogenetic relationships among, S102

Iprobenfos, sensitivity of Magnaporthe grisea to, S45

IR-4 Project registration for specialty crops, update on, S176

IRAC. See Insecticide Resistance Action Committee

Irey, M. S., S41, S84, 1184

Iriarte, F., S156

Iris sp., Phytophthora sp. on, S6

Iris yellow spot virus (IYSV)

ASM for control of, S178

in datura and tobacco, characterization of distinct strains, $\mathrm{S} 12$

in onion, S17, S109, S164, S172

Tomato spotted wilt virus and, in datura, genetic complementation between, S12 in vegetables, in India, 367

Irish, B. M., S277

Irish-Brown, A., 182

Iron, Pseudomonas syringae pv. syringae synthesis of achromobactin and, S64

Ironwood. See Casuarina equisetifolia

Irrig, H. B., S235

Irrigation water

E. coli in, management of, $\mathrm{S} 100$

Phytophthora spp. in, S69, S74, S110

Pythium spp. in, S258

Isard, S. A., S39

Ishimaru, C. A., S232

Islam, K., S171

Islam, K. T., S79

Islas, C. M., S79

Isotianil, for induction of systemic acquired resistance, $\mathrm{S} 233$

Isozaki, R., S55

Isporthiolane, sensitivity of Magnaporthe grisea to, $\mathrm{S} 45$

ISR. See Induced systemic resistance

Ito, S., S56

Ito, T., S56
Iturin, systemic acquired resistance in Arabidopsis thaliana and, S95

Ivors, K., S110, S153, 223

IYSV. See Iris yellow spot virus

Jackai, L. E., S53

Jackson, E. W., S127, 1301

Jackson, G., S218

Jackson, K. L., S79

Jackson, T., S2.1, S2.5

Jackson, T. A., S219, S220, S223, S224

Jacobs, J. L., S188

Jacobs, J. M., S80

Jacon, G., S80

Jahn, M., S64, S80

Jaime, R., S80

Jaime-Garcia, R., S133

Jain, S., S132

Jakobs-Sch $\div$ nwandt, D., S80

Jalan, N., S80

Jalapeño pepper. See Capsicum annuиm

Jamali, S., S81

James, B., S224

James, C., S130

James, D., S248

James, M., S16, S81

James, R. L., S216

Jan, F., S30, S31, S41

Janisiewicz, W. J., S81, S86, S141, S183

Janse van Rensburg, B., S18

Jansky, S. H., 205, 1074

Janssen, D., 1365

Japanese knotweed. See Fallopia japonica

Jaraba, J., S111

Jaragua grass. See Hyparrhenia rufa

Jarausch, B., 1471

Jarausch, W., 1471

Jardini, T. M., 847

Jarosz, A. M., S170

Jarrin, F., S133

Jarugula, S., S81

Jaskani, M. J., S151

Jasmine. See Murraya paniculata; Trachelospermum jasminoides

Jasmonate, molecular mechanism of action, S230

Jaspers, M. V., S178

Jatropha sp., Chrysocoris javanus on, S115

Javan-Nikkhah, M., S88

Jayabal, V., S42, S56

Jean Claude, D., S71

Jeandet, P., 768

Jee, H., S74

Jeffers, S., S38, S131, S181

Jeffers, S. N., S119, S266

Jeffries, P., 1024, 1032

Jefwa, J., S89

Jeger, M. J., 392, 1024, 1032

Jensen, J. D., 960

Jensen, J. E., 960

Jensen, S., S261

Jeon, A., S81

Jeon, M., S100

Jeong, H., S36

Jesus, W. C., S155

Jesus Junior, W. C., S81, S82

Jhan, H., S248

Ji, L., S82, S93, S185

Ji, P., S79, S94

Ji, Y., S82

Ji, Z., S197

Jia, M., S82, S156

Jia, M. H., S82

Jia, Q., S83

Jia, R., S82

Jia, Y., S82, S156, 176

Jiang, C., S83

Jiang, D., S83

Jiang, D. H., S10, 859

Jiang, N., 620

Jiang, Y., S273, S275 
Jibilian, G., S161

Jiménez, P., S120

Jimenez-Diaz, R. M., S83

Jiménez-Díaz, R. M., 250, 304

Jiménez-Fernández, D., 250

Jimenez-Gasco, M., S83

Jiménez-Gasco, M. M., 304

Jin, B., S203

Jin, S., S26, S83

Jin, X., S1, S101

Jin, Y., S25, S127, S132, 1418

Jing, L., S83, S126, S2.4

Jingxin, Z., S148

Jinxue, J., S147

Jinzhong, W., S84

Jo, Y., S36, S205

Jo, Y.-K., S264

Jochum, C. C., S199, S200

Jogi, A., S84

Johnson, C. S., S84

Johnson, D. A., S46, S105, S180, S247

Johnson, E. G., S84

Johnson, E. N., S180

Johnson, J., S59

Johnson, K. B., 113, S194, 299

Johnson, Q., S181

Johnson, R. M., S64

Johnson, S. B., S47, S259

Johnson, T., S172

Johnson-Brousseau, S., S85

Johnson-Brousseau, S. A., S191

Johnson-Cicalese, J., S143

Johnston, B. S., S116

Johnston, J. A., S73

Jomantiene, R., S272

Jonathan, E., S159, S227

Jonathan, E. I., S58, S85

Jones, D., S41

Jones, J., S68

Jones, J. B., S74, S145, 1217

Jones, J. L., S85

Jones, J. M., S22

Jones, M. W., S151

Jones, R., S85

Jones, R. A., S210

Jones, S., S2.2

Jones, T., S85, S216

Joo, J., S109

Jordahl, J., S243, S244, S2.1

Jordan, R., S199

Jørgensen, H. J. L., 231

Jørgensen, L. N., 960

Joseph, H., S85

Joseph, L., S263

Joshua, J. O., S86

Jossey, S., S86

Jouen, E., 887

Juarez, H., S57

Judelson, H., S7

Judice, S., S215

Juglans spp.

J. cinerea (butternut), Ophiognomonia clavigignenti-juglandacearum on, S20, S257, S262

J. nigra (walnut)

Agrobacterium tumefaciens on: evaluating wild trees for resistance, S91; media for improved isolation of, S196

Cherry leafroll virus in, $\mathrm{S} 111$

Geosmithia morbida on: complexity of population structure in US, S201; disease progress in Oregon, S146; genomic and transcriptome analysis, S201; Pityophthorus juglandis and, S138; walnut twig beetle and, S55

Glomerella cingulata on, S99

Jumpponen, A., S62

Junarto, S114

Jung, C., S100

Jung, G., S25, S262

Jung, J., S198
Jurick, W. M., S69, S141

Jurick, W. M., II, S81, S86, S183

Justesen, A. F., 960

Juzwik, J., S86, S245, 404

Köller, W., S128

Kabbage, M., S86, S243, 1251

Kabe, T., S13

Kachroo, A., S230

Kachroo, P., S230

Kadooka, C., S180

Kaewnum, S., S86

Kahlke, C. J., S262

Kahwa, G., 1159

Kajita, H., S55

Kalbande, B., S30

Kale, S. D., S230

Kalia, P., S164

Kaller, M. D., 952

Kalmia latifolia, Phytophthora spp. on, S65, S191

Kalyanasundaram, M., S85

Kamber, T., S232

Kaminski, J. E., S79, S87, S211

Kammeijer, K. E., S52

Kammerer, S. J., S87

Kandel, Y. R., S87, S244, S2.4

Kandouth, B., S87

Kaneshima, E. N., 923

Kang, B., S92

Kang, H., S113

Kang, S., S16, S91, S208, 523

Kang, Z., S201

Kanrar, S., S87

Kantartzi, S. K., S87

Kanto, T., S88

Kanyuka, K., S118

Kaplan, F., S214

Kapulnik, Y., 213

Karasev, A., S47, S57, S182

Karasev, A. V., S57, S88, S154, S230, 778, 1052

Karen, K., S206

Karger, B. D., S273

Karim, A., S227

Karimi Dehkordi, M., S88

Kariyat, R., S119

Karki, H. S., S88, S166, S266

Karthikeyan, A., S112

Karthikeyan, G., S4, S42, S56, S159, S227, 1446

Karuppuchamy, P., S85

Kasson, L. R., S88

Kasson, M. T., S88, S89

Kasugamycin

and copper or mancoxeb for walnut blight management, $\mathrm{S} 2$

for management of Erwinia amylovora, 192

Kasun, G., S188

Katagiri, F., S58, S208

Katan, J., S92

Katori, M., S6

Kaur, I., S266

Kaur, R., 1081

Kaushik, N., S227, S234

Kavoo, A. M., S89

Kawasaki, T., S2, S55

Kawaura, K., S94, S177

Kaye, A. C., 147

Kayentao, M., S232

Kazi, T., S153

Ke, Y., S103

Kebede, Y., S232

Keichinger, C., S63

Keinath, A., S89, S189

Keith, L., S89

Keith, L. M., S129

Kelemen, R., S109

Keller, K. E., S154, S158

Keller, K. K., S70

Keller, N., S230

Kelly, M. K., S22

Kema, G., S43, S142
Kema, G. H., S208

Kemerait, R. C., S9, S56

Kemerait, R. C., Jr., S266

Kemmochi, I., S13

Kendrick, M. D., S139, 535

Kennaway, L., S216

Kennedy, G., S75

Kennelly, M. M., S211

Kepich, D. J., S22

Keremane, M., S69

Kerlan, C., S57, S88, 778, 1052

Kerman Province, Iran, fungal diseases of ornamental plants in, S13

Kermes scale. See Allokermes sp.

Kerns, J., S153, S187, S211, S2.9

Kerns, J. P., S192, S268

Keshavarsi, M., S163

Kessler, J. O., S40

Ketelaar, J., S227, S234

Key lime. See Citrus aurantifolia

Key to the Common Phytophthora species, overview of, S153

Khafipour, E., S102

Khalaf, A. A., S5

Khallouk, S., 945

Khan, A., S15

Khan, A. N. A., S145

Khan, I., S238

Khan, I. A., S150, S151

Khan, M., S245, S246

Khan, M. F., S89

Khan, N., S238

Khan, N. I., S259

Khoa, N. D., 231

Khozeini, F., S175

Kiepe, P., S6

Kiewnick, S., S90, 105

Kikawada, T., S173

Kikuchi, S., S182

Kikuyugrass. See Pennisetum clandestinum

Kilbourne, K., S90

Kim, D., S35, S90, S92

Kim, G., S239

Kim, H., S86, S92, S100, S198, S231

Kim, I., S91, S231

Kim, J., S35, S67, S74, S90, S91, S100, S137

Kim, J. D., 666

Kim, J. F., 935

Kim, K., S36, S91, S99, S137

Kim, K. D., 666, 732

Kim, M., S91, S92, S127, S171

Kim, N., S100

Kim, S., S91

Kim, T., S91

Kim, W., S36, S74

Kim, Y., S74, S90, S137, S165, S231

Kim, Y. K., 986, 1385

Kimberley, M. O., 583

Kinard, G., S105, S143, S195

Kinzer, K., S244

Kinzer, K. M., S2.5

Kippley, T., S80

Kirk, W. W., S200, S244

Kirkpatrick, B., S141, S188

Kirkpatrick, B. C., 1492

Kirkpatrick, T., S111

Kirkpatrick, T. L., S209, S267

Kistler, C., S208

Kistler, H. C., S57, 124

Kitajima, E. W., S104, S272

Kitto, S. L., S97

Kitzmann, E., S2.4

Klaassen, V. A., S61

Kladnik, A., 1292

Klebsiella pneumoniae, comparative genomic analysis of, S212

Klein, E., S92

Klein, J., S87

Klein-Gebbinck, H., S179

Klessig, D., S113 
Klessig, D. F., S92

Kliejunas, J., S135

Klimaszewska, K., S262

Klindworth, D., S132

Klingeman, W. E., S2

Klink, V., S99

Kloepper, J., S270

Kloepper, J. W., S29, S161, S204

Klopfenstein, N. B., S92, S127, S171

Klopfentein, N. B., S127

Klosterman, S. J., S10, S46, S115, S208

Klotzbach, K., S65

Kluepfel, D. A., S92, S196

Knake, R. P., S124

Knepper, C., S2.5

Knezevic, S., S92

Knodel, J., S2.6

Knowles, R. L., 583

Knudsen, G. R., S91

Ko, J., S100

Ko, S., S91, S92

Koa trees. See Acacia koa

Kobayashi, D. Y., S116, S138, S231

Kobayashi, S., S177

Koch, A., S133, S183

Koch, P. L., S192

Koebnik, R., S193

Koenig, S. M., S2.5

Kogovšek, P., 1292

Kohn, F., S93

Kohn, L., S39, S221

Koike, S., S79

Koike, S. T., S46, S52, S95, S116, 340, 358, 523, 847

Koita, O., S193

Kokalis-Burelle, N., S32, S156

Kolmer, J. A., 870

Kolomiets, M. V., S230

Koltai, H., 213

Komatsu, K., 567

Komatsu, M., S3

Komives, T., S93, S237

Komorowska-Jedrys, J., S258

Kon, T., S119

Kong, H., S93, 271

Kong, L., S82, S93, S198

Kong, P., S74, S93

Kopsell, D. A., S165

Kopzhassarov, B., S177

Korban, S., S186

Korban, S. S., 710

Korus, K. A., S2.5

Korzun, V., 1209

Kosta, K. L., S85

Kouadio, L., S47

Koundal, V., S30, S93

Kousik, C. S., S94, S176

Kovacs, S., S215

Koval, N. C., S241

Koziol, L., S25

Kraus, T. E., S115

Krause, D., S102

Kretzmer, K., S93

Kreuze, J. F., S215

Kriesemer, K., S225

Krishnan, K., S94

Kriss, A., S48

Kriss, A. B., S221

Kriticos, D. J., S179

Kroschel, J. E., S57, S226

Krugner, R., S184

$\mathrm{Ku}, \mathrm{H}$., S30

Kuang, W., S202

Kudzu. See Pueraria spp.

Kuehn, S., S93

Kuhn, P., S94

Kuldau, G. A., 1091

Kulye, M., S199

Kumar, D., S94

Kumar, J., S112
Kumar, K. K., S204

Kumashiro, S., S94

Kumashiro, T., S6

Kumquat. See Citrus japonica

Kund, G., S113

Kung, Y., S198

Kunjeti, S., S94, S273

Kunjeti, S. G., S94, S273

Kunkalikar, S. R., 367

Kunta, M., S95, S175

Kuo, Y., S95

Kurdyla, T., S95

Kurosawa, Y., S95

Kurose, D., S56, S95, S179

Kurucheve, V., S96

Kusumah, Y. M., S224

Kutcher, H. R., S179, S180

Kuwitzky, B. E., S2.5

Kuykendall, L., S96

Kuykendall, L. D., S70

Kwak, H., S91

Kwan, G., S96

Kyamanywa, S., S228, S234

Labbé, C., S260

Laborte, A., S223

Labrada, R. E., S237

Labun, T., S165

Lacava, P. T., S96

Lactoferrin, resistance of transgenic plants expressing against Rhizoctonia solani, S97

Lactuca sativa (lettuce)

Coniothyrium minitans and, 358

E. coli $\mathrm{O} 157: \mathrm{H} 7$ on, transcriptomic analysis, S212

Fusarium oxysporum on, pathological and molecular race determination, $\mathrm{S} 31$

Salmonella enterica on, antagonistic yeasts for control of, S66

Sclerotinia spp. on impact of consumer-driven changes to crop production practices on, 340

S. minor on, S249, 358

S. sclerotiorum on, S249

Tomato spotted wilt virus in, nucleocapsid protein gene for pathogen-derived resistance in, $\mathrm{S} 3$

Laetisaria arvalis, for control of Pyrenophora teres on barley, $\mathrm{S} 98$

Lafferty, J., S161

Laflamme, G., S260

LaForest, J., S73, S96, S219

LaForest, J. H., S161

Lage, D. A., S97

Lagos Mora, L., S120

Laguette, S., S153

Lai, P., S31

Lai, W., S180

Lakshman, D., S93

Lakshman, D. K., S97, 271

Lakshmanan, V., S97

Lalancette, N., S97

Lalève, A., 1176

Lamb, P., S73

Lambert, D., S138

Lambert, D. H., S259

Lambs lettuce (Valerianella olitoria), Fusarium oxysporum on, $\mathrm{S} 65$

Lamium amplexicaule (henbit), Heterodera glycines on, $\mathrm{S} 2.9$

Lamo, J., S6

LaMondia, J. A., S1, S260

LAMP (loop-mediated isothermal amplification) assays

for detection of Erysiphe necator on grape, S112

for detection of Plum pox virus, S58

Lamppa, R., S242, S245, S2.7

Lampton, P., S215

Landa, B. B., 250, 304, 1168
Landero-Valenzuela, N., S98, S128

Landgren, C., S31

Landi, L., S156

Landscape epidemiology, scale-dependent, S167

Lane, S., S134

Laney, A. G., S97, S145

Langa, M., S6

Lange, H. W., S260

Langham, M., S2.5

Langham, M. A., S161, S2.5

Langston, D., S259

Langston, D. B., S97, S159, S269

Lannon, K. R., S98

Lantana camara, as invasive weed, S238

Lanteigne, C., S98

Laodelphax striatellus (small brown planthopper), insecticide resistance in, S159

Lapidot, M., 281

Lara-Viveros, F. M., S3, S98, S128

Larix spp., Armillaria solidipes on, S91

Larkin, R., S132

Larkin, R. P., S30, S98, 135

Larsen, M., 166

Larson, C., S2.6

Lartey, R. L., S24

Lartey, R. T., S98

Lasiodiplodia theobromae on blueberry, S194

on grape, pycnidial development, pycnidiospore germination and, S39

Late blight. See Phytophthora infestans

Latin, R., S41

Latoni, E., S154

Latoni-Brailowsky, E., S254

Latoni-Brailowsky, E. I., S277

Latorre, B. A., S42, S99

Latorre, M., S6

Lau, W., S85

Laurel wilt disease. See Raffaelea canadensis

Laurus nobilis (bay laurel), Phytophthora ramorum on, influence of forest type on transmission of, 492

Lauter, N., S2.4

Lava Kumar, P., S78, S158

Lawrence, A., S158

Lawrence, C. B., S230

Lawrence, G., S99

Lawrence, K., S162

Lawrence, K. S., S29, S99, S123, S161

Le, P. T., S165

Le Pêcheur, P., 1433

Le Strange, M., S250

Leach, J., S48, S100

Leach, J. E., S168, S178, S182, S183, S217

Lea-Cox, J., S74

Lea-Cox, J. D., S93

Leadbeater, A. J., S235

Leadbetter, C., S25

Leandro, L., S42, S171

Leandro, L. F., S175

Lebeau, A., 154

Lebeda, A., S99, S149

Lebeis, A., S63

LeBlanc, M., S239

Lecomte, P., S14, S21

Lee, B., S100

Lee, D., S91

Lee, G., S100

Lee, H., S36

Lee, I., S214, S272, S273, S275

Lee, J., S97, S99, S100, S137, S169

Lee, K., S104, S121

Lee, M., S74, S99

Lee, R., S69

Lee, R. F., S113, S150, S151

Lee, S., S91, S99, S100, S137

Lee, T., S180

Lee, W., S90

Lee, Y., S36, S74, S76, S92, S100, S165, S169, S198, S208 
Lefebvre, F., S260

Legault, G. S., 1045

Legg, J. P., 1159

Legrève, A., 1149

Legumes

integrated management of diseases for sustainable rainfed agroecosystems, S226 real-time disease/pest monitoring and reporting network for, S161

Lehman, B. L., 512

Lehmann, A., S19

Lei, L., S82, S2.6

Leifsonia xyli subsp. xyli, on sugarcane, S180

Lemanceau, P., S70

Lemon. See Citrus limon

Lens culinaris (lentil), new broad-spectrum fungicide for, S115

Leon, G. A., S36

Leonberger, A. J., S244

Leppla, N. C., S234

Leptographium longiclavatum, mountain pine beetle and, population genetic analysis of, S51

Leptosphaeria maculans, on canola increasing diversity of, S127 population genetic analysis of, S127

Lerat, S., 1045

Leroch, M., 1176

Lesan, M., S2.4

Leslie, C. A., S111

Leslie, J. F., S165, S199

Lesniak, K. E., S2.6

Lettuce. See Lactuca sativa

Leuconostoc mesenteroides, on sugar beet, storability and, S172

Leveillula taurica, on tomato, impact of irrigation system on, S97

Lévesque, A. C., S247

Levesque, C., S214

Levy, J., 1285

Levy, L., S36, S95, S106, S117, S125

Levy, L. E., 627

Levy, M., S221

Lewandowski, D. J., S2.4

Lewers, K., S69

Lewis, K. J., S11, 68

Lewis, R. S., S98

Lewis, S., S134

Lewis Ivey, M. L., S100, S101

Leytem, A. B., S101

Li, B., S83, S111, S185

Li, C., S189, S195

Li, D., S32, S163, S205

Li, F., S102, S195

Li, G., S83

Li, G. Q., 859

Li, H., S58, S101, S102, S104

Li, J., S101, S103, S187

Li, J.-G., 1202

Li, K., S45

Li, M., S58, S103, S107, S187, S197

Li, Q., S82, S93, S103

Li, R., S102, S105, S142, S143, S195, S209

Li, S., S101, S103, S111, S112, S209

Li, W., S95, S102, S125

Li, X., S103, S106, S189, S203

Li, X.-D., 377

Li, Y., S82, S101, S102, S260

Li, Z., S195, S224, 620

Liane, M., S2.6

Liang, C., S58, S68

Liang, X., S66

Liang, Y., S180

Liangsheng, X., S104

Liao, J. L., 1270

Liao, P.-L., 741

Libault, M., S150

Liberti, D., S39, S104, S182, S199

Lichtemberg, P. S., S44

Liess, L., S159, S250

Lieth, J. H., 1492
Lilac. See Syringia spp.

Liles, M. R., 52, 819

Lilium spp. (lily)

Bacillus sereus and induced systemic resistance in, S248

Botrytis cinerea on, B. cereus for resistance against, S76

Lim, C. K. S231

Lim, H., S181

Lim, L., S188

Lima, A. T., S104

Lima, G. S., S166

Lima, M. P., S43

Lima bean. See Phaseolus lunatus

Lime. See Citrus spp.

Lin, B., S35

Lin, F., S209

Lin, H., S105, S107, S190, S206

Lin, L., S105

Lin, M., S150

Lin, S., S104

Lin, Y., S31, S34, S37, S105

Lin, Y.-H., 741

Lin, Z., S199

Lincus sp., and sudden wilt of oil palm, S253

Lindow, S. E., S32, 77, S178

Ling, K., S106

Lingmin, M., S148

Linlin, M., S84

Lipids

role in host-pathogen interactions, S230 systemic acquired resistance and, $\mathrm{S} 91$

Lipopolysaccharide, virulence and host specificity of Xylella fastidiosa and, S38

Lipoxygenases, as signals in cross-kingdom communications regulating disease progression, S230

Liriodendron tulipifera, Phytophthora kernoviae on, S191

Litt, A., S18

Little, C. R., S19, S140

Liu, A., S33

Liu, B., S108, S139, S173

Liu, D., S107, S108

Liu, E., 620

Liu, G., S82, 176

Liu, H., S83, S107, S119, S129, S186, S187, S195

Liu, H.-X., 1202

Liu, J., S48, S107, S108, S176, 620

Liu, J. L., 377

Liu, J.-J., 904

Liu, L., S83

Liu, P., S92, S107, S113

Liu, Q., S106, S108, S197, S203

Liu, R., S83

Liu, S., S106, S108, S248, S251

Liu, T., S107, S148

Liu, W., S103, S107, S108, S109, S148

Liu, X., S34, S110, 620, 1104

Liu, Y., S106, S248

Liu, Y. Y., 377

Liu, Z., S106, S107, S189, S199, S204

Live coating seed, Pseudomonas fluorescens on tomato and, S116

Livingstone, D. M., 786

Llop, P., S232

Lloyd, M. G., S109

Lo, C., S106, S108, S109

Lobin, K., S109

Lobo Junior, M., S60, S109

Loconsole, G., S43

Locoweeds. See Astragalus spp.; Oxytropis spp.

Locusta migratoria, on wheat, effect of barley chromosome addition, S177

Lohrke, S. M., 271

Lohse, R., S80

Lolium latent virus (LoLV) coat protein forms of, systemic movement and, S181

virus-like particles of as chemical bio-conjugate substrates, S126
Lolium perenne (perennial ryegrass)

genetic structure of Magnaporthe grisea populations associated with, 85

Magnaporthe oryzae on, effect of intermittent leaf wetness on, S101

Lomatium spp., Pseudomonas syringae on, S159

Lommel, S. A., S137

Long, D., S184

Longan. See Dimocarpus longan

Lookabaugh, E., S109, S110

Loose smut. See Ustilago nuda

Loper, J., S117

Loper, J. E., S26, S70, 113, S172, S231, 299

Lopes, S., S41

Lopes, S. A., S110

Lopéz, C. E., S179

Lopez, M., S2.4

Lopez Nicora, H. D., S110

López-Cruz, I., S151

López-Vega, J. R., S154

Lord, W. G., S262

Lorè, A., S66

Lore, J. S., S112

Lorito, M., S160

Loughman, R., 1278

Louws, F., S45, S108, S139

Louws, F. J., S27, S79, S173, S178

Lowder, C., S15

Lowenstein, F., S20

Loxostege sticticalis (beet webworm moth), population source of first generation in China, S202

Loyd, A., S110

Lu, C., S107

Lu, S., S33

Lu, X., S34, S45, S110, S111, 1104

Lu, X. H., S110

Lu, Y., S195

Luck, J. E., S53

Ludwig, G., S235

Luo, C., S76

Luo, H., S26

Luo, L., S187

Luo, M., S21

Luo, W., 1184

Luo, Y., S111

Luongo, L., 679

Lupien, S. L., S46

Lupinus spp. (lupin), Colletotrichum acutatum on, S51

Luster, D. G., S78, S146, 627

Lustosa, D. C., S166

Luther, G., S225

Lycopersicon esculentum. See Solanum lycopersicum

Lydon, J., S93, 271

Lyles, J. L., S268

Lynch, S., S111

Lynch, S. C., S248, S249

Lynn, N., S111

Lynnes, T. C., S62

Lysobacter enzymogenes

for control of Magnaporthe oryzae on rice, S116

pathogenesis as mechanism of biological control by, S231

role of type IV pilus in, S138

Ma, B., S111, S267

Ma, C., S112

Ma, J., S111, S209

Ma, L., S43, S59, S208

Ma, P., S111

Ma, X., S187

Ma, Z., S173

Ma gene, and resistance against Meloidogyne incognita, 945

MABYV. See Melon aphid-borne yellows virus

MacCormack, R., S220

MacDonald, J. D., S147

MacDonald, M., S126 
Macedo Pezzopane, J., S81

MacGuidwin, A. E., S209

MacHardy, W. E., S262

Maciel, J. L., S221

Mackasmiel, L., S86, S112, S121

MacKenzie, S., S140

MacRae, I. V., S153

Macrophilum lathyroides, begomoviruses in leguminous weeds and, S166

Macrophomina phaseolina

on Medicago trunculata, S166

mycoviruses for biological control of, S169

on snap bean, S26

on soybean, S11, S26

on strawberry, S117, S156, S249

on sweet potato, S138

Macroptilium yellow spot virus (MaYSV), in

leguminous weeds, S166

Madden, L., S170, S191

Madden, L. V., 16, S221, S228, 512, 654, 1122 1366

Maddox, J., S222

Madigascar periwinkle. See Catharanthus roseus

Maeda, K., S165

Maejima, K., 567

Maffia, L., S75

Magarey, R. D., S46

Magculia, N. F., S112

Maghsoudi, M., S112

Magill, C. W., S140

MagMV. See Magnolia mosaic virus

Magnaporthe spp.

cellular and molecular responses of wheat to, S220

evaluation of differentiation between, $\mathrm{S} 112$

M. grisea

contrasting genetic structure of populations associated with turfgrasses, 85

fungicide sensitivity of, S45

on wheat: international perspective on S220; risk mapping potential in Brazil, $\mathrm{S} 221$

M. oryzae

mapping quantitative trait loci for resistance to, 176

OsERF9, biotic and abiotic stress responses and, $\mathrm{S} 108$

$P c g 2$ pathogenicity gene in, S187

on perennial ryegrass, effect of intermittent leaf wetness on, S101

on rice: chitinase gene and disease resistance, S100; determination of geographic origin of different pathovars, S182 ethylene overexpression for resistance against, S71; GATA factor and virulence, S2.8; influence of weather factors on, S52; inhibition by Sarocladium oryzae, S166; Lysobacter enzymogenes for control of, S116; molecular mapping of resistance genes in cultivar Xiangzi 3150, 620; mutated lines showing improved resistance to, $\mathrm{S} 148 ; \mathrm{PaC}$ mediated adaption to alkaline $\mathrm{pH}$ and, $\mathrm{S} 140$; PCG1 gene and pathogenesis of, S198; phenomics of, S149; $P i-b$ resistance gene and, S156; $P$ i-ta locus and, S82; reactive oxygen species, MoHYR1 and, S76, S273; rhizobacteria in defense of, S5; small RNAs and biosynthetic genes of, pathogenicity and, S150

secretory protein pathogenicity, S205

on wheat: gene flow levels 20 years after first epidemics, S221; resistance among US cultivars, S220; standardization of protocols to test for, S40; susceptibility of select US cultivars, S141

zinc-finger effectors, plant cell death and immunity and, S108

M. poae, on turfgrasses, $\mathrm{S} 204$

on rice, mode of infection, S202
Magnolia mosaic virus (MagMV), in Umbrella tree, S158

Magnolia tripetala, Phytophthora kernoviae on, S191

Magnus, D., S237

Mah, K., S166

Mahaffee, W., S112

Mahaffee, W. F., S139, S249, 644

Mahalingam, C. A., S85

Mahanil, S., 502

Mahmoudi, B., S169

Mahoney, N., S156

Maia, A. H., S60

Main, D., S77

Maize chlorotic mottle virus (MCMV), corn thrips, transmission and, S24

Maize dwarf mosaic virus (MDMV), in corn, Wsm genes and, S151

Maize fine streak virus (MFSV), optimization of protein expression in Drosophila S2 cells, S37

Maize mosaic virus (MMV), in corn, Peregrinus maidus fitness and wing morphology and, S72

Maize rayado fino virus, virus-like particles of as chemical bio-conjugate substrates, S126

Maize streak virus (MSV), in corn, S158

Maize wallaby ear. See Cicadulinia bipunctata

Makimoto, Y., S113

Makowski, D., 1346

Malaviscus yellow mosaic virus (MalYMV), in

Malvaviscus arboreus, $\mathrm{S} 104$

Malcolm, G. M., S83

MALDI-TOF MS, for rapid bacterial identification and phylogenetic analysis, S145

Malic acid, Pseudomonas syringae pv. tomato on tomato and, S97

Malick, B., S130

Malinoski, M. K., S117

Malinowski, T., 980

Malus spp. (apple)

Alternaria mali on, S155

Botryosphaeria dothidea on, S175

Botrytis cinerea on

boscalid resistance and, 986, 1385

endogenous ethylene biosynthesis and resistance to, 1311

multiple resistance phenotypes of, $\mathrm{S} 90$ pyraclostrobin resistance and, 1385

Candidatus Phytoplasma mali on, Cacopsylla picta and spread of, 1471

Colletotrichum spp. on, fungicide sensitivity of, S2.5

Eremothecium coryli on, brown marmorated stink bug feeding and, S22

Erwinia amylovora on

analysis of products evaluated for control of, 512

genes regulated by $\mathrm{RcsB}$ and $\mathrm{RcsC}$ in, S186

Pantoea agglomerans E325 against on flower stigmas, S146, 1234

RcsC sensor kinase from, 710

streptomycin-resistant, S128

meta-analysis to determine effects of disease management measures in, 31

Neofabrea spp. on, S251

Neonectria galligena on, 135

new broad-spectrum fungicide for, S184

non-target effects of glyphosate on, S262

Penicillium spp. on, S141, S182

penthiopyrad partitioning and efficacy in S142

Rhizoctonia solani on, Brassica juncea seed meal-induced suppression of, S249

seed meals for disease control in organic orchards, S117

sooty blotch and flyspeck on, S2.6

Venturia inaequalis on genetic diversity and temporal dynamics, S83 integrated pest management and fungicide resistance and, S213

multiple fungicide resistance and, S128 post-harvest foliar urea sprays for, S262 rapid detection of fungicide resistance, S2.3 seasonal distribution of fungicide resistance, S114, S274

survey of fungicide resistance, S242

tank mixing of dodine for, $\mathrm{S} 80$

$V f$-resistant cultivars and, S14

Xanthomonas spp. on, S163

Malvick, D., S63, S171, S2.2

Malvick, D. K., S243, 1122

MalYMV. See Malaviscus yellow mosaic virus

Mamidi, S., S2.7

Mancino, L. E., 805

Mancoxeb

for Alternaria solani on tomato, S2

and kasugamycin for walnut blight management, S2

Mandal, M. K., S230

Mangifera indica (mango)

Batrocera invadens on, S182

Colletotrichum spp. on, S255

phytopathogenic fungi associated with, S253

thrips and pathogenic fungi in inflorescences of, S255

Xanthomonas citri pathovars on, insertion sequence- and tandem repeat-based genotyping techniques for, 887

Mangosteen. See Garcinia mangostana

Maniania, J. N., S224

Manihot esculenta (cassava, manioc)

cassava mosaic disease of, whitefly vector populations and, S210

Xanthomonas axonopodis pv. manihotis on, S152, S179

Manisterski, J., 870

Manjunath, K. L., S113, S150, S151

Manjunath, S. V., S145

Manjunatha, S. M., S164

Manker, D., S184

Mann, H., S18

Manoranjitham, S. K., S58, S143

Manosalva, P., S113

Mansfield, M. A., S65, S274

Mansouri, S., S79, S113, S171

Mansur, T. O., S200

Manulis-Sasson, S., S136

Manzo-Sánchez, G., S133

Maomiao, H., S147

Marahatta, S. P., S113

Maraite, H., S47

Maramorosch, K., S278

Mararuai, A. N., S220

Marasas, C., S114

Marchant, B. P., 725

Marco, M. L., S212

Maredia, K. M., S226

Marek, S., S9

Marelli, F., S65

Marelli, J., S274

Maria, E., S114

Marine, S. C., S114, S274

Markell, S., S4, S115, S241, S243, S245, S2.1, $\mathrm{S} 2.2, \mathrm{~S} 2.6, \mathrm{~S} 2.7$

Markell, S. G., S62, S138, S2.3, S2.5

Markle, D., S2.6

Märländer, B., 1330

Marois, J., S170

Marois, J. J., S199

Maroon-Lango, C., S114

Maroon-Lango, C. J., S96

Marouelli, W. A., S97

Marquez-Villavicencio, M., S114

Marra, R. E., S261

Marrero, G., S114, S161

Marrone, P., S172

Marroquín-Guzman, M., S253

Marsh, A. G., S94, S273

Marshall, J. M., S16 
Martens, G. M., S115

Martin, B., S54

Martin, C. A., S217

Martin, D., S112, S249

Martin, F., S16, S230

Martin, F. N., S10

Martin, J., S18

Martin, M. L., S235

Martin, R. R., S70, S115, S149, S154, S158

Martinez, G., S253, S254, S255

Martínez-Bolaños, L., S133

Martinho, D., 1433

Martini, M., S255

Martin-Lapierre, A., S261

Martins, O. M., S115, S116

Maruca vitrala multiple nucleopolyhedrovirus

(MaviMNPV), as biological control agent in

Taiwan, S224

Maruthachalam, K., S10, S46, S115, S208

Marx, B., S216

Maryana, N., S115

Masamdu, R., S219

Masamdu, R. T., S219

Masdek, N., S122

Masri, S., S248

Massively parallel sequencing

for detection of Phytophthora ramorum, S50

for detection of Puccinia graminis, S50

as diagnostic tool, S172

in silico simulation of as diagnostic tool, S41

Massot, M., S21

Masuta, C., 575

Matheron, M. E., S115, S249

Mathew, F., S115, S243, S245, S2.1, S2.2, S2.7

Mathews, D. M., S116

Mathieson, T., S2.6

Mathioni, S., S116

Mathiyazhagan, S., S42

Mating disruption, for control of Planococcus

ficus on grape, $\mathrm{S} 120$

Mating type loci

Sclerotinia spp. and

S. homeocarpa on turfgrasses, S147

Sclerotinia sclerotiorum apothecia formation, S35

Matsuguma, Y., S116

Matsukura, K., S94, S116

Matsumoto, M., S11

Matsumoto, T., S89

Matsumura, M., S94, S116, S159

Matsuura, K., S88, S233

Matthews, B., S126

Matthews, B. F., S209

Mattos, C. R., S75

Maturity Group IV soybean, maintaining seed quality of, S5

Matveeva, E., S78

Mauceli, E., S208

Mauck, K., S119

Maul, J., S72

Mauleon, R. P., S182

Mauzey, S. J., S116

MaviMNPV. See Maruca vitrala multiple nucleopolyhedrovirus

Mavrodi, D., S117

Mavrodi, D. V., S201, S231, 996, 1481

Mavrodi, O., S117

Mavrodi, O. V., S201, 1481

Mavrodieva, V., S106, S117, 627

Maximova, S., S272

Maximum residue limits (MRLs), as growing export issue, $\mathrm{S} 235$

May De Mio, L. L., S17, S155

Mayfield, D. A., S2.6

MaYSV. See Macroptilium yellow spot virus

Mayton, H., S263

Mazurier, S., S70

Mazurin, E., S78

Mazzola, M., S117, S249

Mbata, G., S228
Mbui Martins, M., S278

McAvoy, R. L., S48

McAvoy, T., S136

McBeath, J. H., S44, S239

McCabe, K., S174

McCall, D. S., S144

McCallister, J. E., S114

McCarthy, R. L., S73

McCartney, N., S16

McClean, A. E., S92

McClelland, M., S176

McClung, A. M., S204, S205, S270

McClure, M., S129

McConnachie, A., S238

McConnell, M. E., S117

McCoppin, N. K., 750

McCoy, S., S278, S2.7

McDonald, B. A., S221

McDonald, M. R., 1424

McDonald, V., S50

McDowell, J. M., S230

McDuffee, D., S118

McFadd, T. K., S215

McFadden-Smith, W., S259

McFarland, K., S97

MCG. See Mycelial compatibility groups

McGhee, G. C., S118, 182, 192

McGovern, R. J., S234

McGrann, G. R., S220

McGrath, M. T., S118, S261

McHale, L., S100

McKay, A., S118

McKee, B., S135

McKenna, L., 271

McKenzie, D., S37

McLaren, D., S30

McLean, H., S94

Mcmechan, A. J., S2.6

McMillan, R. T., S175

McMillan, V. E., S118

McMullen, M., S244, S2.6

McMullen, M. V., S2.3

McNally, R. R., S118

McNellis, T. W., S274

McOwen, N., S157

McPhee, K., S2.9

McPhee, K. E., S2.5

McRoberts, N., S152, 654, 696

McSpadden Gardener, B., S41, S137

McSpadden Gardener, B. B., S120

MCW-2, for Meloidogyne javanica on carrot, tomato, and cucurbits, S190

Meacham, T., 1052

Meacham, T. M., S154

Meadows, I. M., S119, S266

Mealybugs. See Dymiococcus spp.; Ferrisia virgata; Paracoccus marginatus; Phenacoccus solenopsis

Medford, J. I., S178

Medicago spp.

M. sativa (alfalfa)

Bean leafroll virus in, S182

Phoma sclerotioides on, S29, 594

Sclerotinia sclerotiorum on, sclerotial survival and natural biological control, S144

M. trunculata, Macrophomina phaseolina on, S166

Medrano, E. G., S119

Mefenoxam, for control of Pythium spp., S110

Mehl, A., S229

Meinhardt, L., S272

Meinhardt, S. W., S62, S2.7

Mejía, J. F., S253

Mekanya, C. O., S131

Mekete, T., S110

Mekuria, T., S85

Melanin, Alternaria brassicicola infection and, S36

Melanson, R. A., S266, S267

Melcher, U., S135, S155
Melcher, U. K., S171

Melgar, J., S153

Melgarejo, T. A., S119

Melis, R., S124

Mellinger, H., S189

Melloy, P., S53

Melnick, R. L., S272, S274

Meloidogyne spp. (root-knot nematodes)

alteration of host gene silencing during infection with, S185

barcoding for identification of, S90

chemical ecology and isolation of chemically active compounds from, S214

M. chitwoodi, on potato, S214

M. enerolobii, Paecilomyces lilacinus strain 251 for control of, S90

on golf course greens in western US, S129

$M$. hapla, genome of encoding suites of plant peptide hormone mimics, S42

identification by multiplex PCR protocol, S90

M. incognita

Aspergillus niger Y-61 for control of, S148

on corn, Fusarium oxysporum f. sp. vasinfectum and, S270

on cotton: engineering resistance by RNAi mediated silencing of parasitism genes of, S61; host resistance, S265; management of in multiple soil types with Telone II, S266; QTL analysis for transgressive resistance, S187; root morphology in field and, S111; Thielaviopsis basicola and, S209

on cucumber, fluensulfone for control of, S97

Gymnoascus reessii za-130 for control of, extraction of active component from, S107

organic sulfide fumigants for suppression of in greenhouse, $\mathrm{S} 112$

Paecilomyces lilacinus for control of, 92

on pepper: co-infection with Phytophthora capsici and, S176; fluensulfone for control of, S97, S131

on potato, $\mathrm{S} 87$

on Prunus spp., Ma gene and resistance against, 945

response of to silicon, $\mathrm{S} 267$

on soybean: impact and management of, S267; potential resistance to, S99

on tomato, B. cereus AR156 and resistance in, $\mathrm{S} 129$

M. javanica

on carrot, tomato, and cucurbits, MCW-2 for management of, S190

Veronica anthelmintica for control of, S173 multiplex PCR using DNA extracted from galls, 1270

resistance to, $M i$ resistance gene and, 410

on tomato, effect of cover crops on, S120

Meloidogyne virulence correlated (MVC) molecu-

lar marker, virulence of Meloidogyne spp. and, 410

Melon. See Citrullus spp.; Cucumis spp.

Melon aphid-borne yellows virus (MABYV), multiplex RT-PCR for detection of mixed infections with, S163

Melouk, H., S30, S59

Melouk, H. A., S2, S20

Melzer, M., S42, S119

Melzer, M. J., S229

Mena-Ali, J., S119, S163

Mendes, M., S265

Mendes, O., S18

Meng, L., S185

Meng, Q., S119, S244

Mengesha, B. G., S167

Mengiste, T. D., S167

Mengistu, A., S11, S26

Menkir, A., S21, S158

Mentha spp. (mint, peppermint), Verticillium 
dahliae on, S46, S247

Menzies, J. G., S183

Meon, S., S192

Mera, J., S14

Mercier, M., S63, S149

Mercier, M. R., 1061

Merivon, for diseases of pome fruits, stone fruits, fruiting vegetables, and potatoes, S184

Mernke, D., 1176

Merremia mosaic virus, infectivity in Nicotiana benthamiana, S277

Mersha, Z., S120, S202, S216

Mersie, W., S238

Mescher, M., S119

Mescher, M. C., S231

Meshram, M. K., S61

Mesonet radar, pecan scab predictions and, S138

Mesquite, Pleochaera polychaeta on, S129

Mestizo, Y., S254

Meta-analysis

Bayesian approach to, 42

to determine effects of plant disease management, 31

for evidence synthesis in plant pathology, 16

of products evaluated for control of fire blight in the eastern United States, 512

of yield response of hybrid field corn to foliar fungicides in the U.S. corn belt, 1122

Metagenomes, simulated

detection of Phytophthora ramorum in, S50

detection of Puccinia graminis in, S50

as diagnostic tool, S41

Metarhizium anisopliae

for control of hopper bands of locusts and sahelian grasshoppers, S224

for control of sugar cane pests, S224

genes from in Trichoderma koningi, S33

Metconazole

Fusicladosporium carpophilum and Alternaria spp. on almond and, S54

for Rhizoctonia solani, on sugar beet, S118

Methyl bromide

alternatives to for strawberry, S129

ASI-261 as alternative to, S156

on-farm research for implementation of alternatives of, S45

microbial ecology of fumigated vs. nontreated soils for strawberry production, S139

Methyl salicylate, systemic acquired resistance and, S91

Methylobacterium mesophilicum, Xylella fastidiosa on citrus and, S96

Methylobacterium spp., coffee and, S278

Metschnikowia spp., glucanase and chitinase from, S66

Metz, S., S93

Mexican lime. See Citrus aurantifolia

Mexican papita viroid (MPVd)

in tomato, deep sequencing for identification of, S106

Meyer, M. M., 1492

Meyer, R. S., S18

Meyer, S., S243, S245, S2.1, S2.7

Meyer, S. L., S120

Meyer, S. M., S244

Meyers, B. C., S94, S150, S273

Mi resistance gene, Meloidogyne spp. (root-knot nematodes) and, 410

Mian, M., S100

Miano, J. L., S120

Miao, H., S82

Miao, Z., S112

Michailides, T. J., S17, S44

Michalczuk, L., 980

Miconia calvescens, as invasive weed, S238

Microbotrym spp., evolutionary relationships among, S163

Microcyclus ulei, on rubber, S75

Microdochium spp., species complex and related mycotoxins, 960
Microsclerotium, disease properties of Ramulispora sorghi on sorghum and, S19

Microsphaeropsis amaranthi, for control of waterhemp and redroot pigweed, S134

Middleton, G., S69

Mideros, M., S120

Miedaner, T., S120, 1209

Mielenz, J. R., S174

Mielli, M. V. B., 92

Mikania micrantha, as invasive weed, S238

Mila, A., 696

Mila, A. L., 42, 462

Miles, T. D., S120

Milgroom, M. G., S20, 839

Milk vetch. See Astragalus sinicus

Miller, J. G., S267

Miller, S., S60

Miller, S. A., S14, S100, S101, S195, S228

Miller, T. A., S96

Millet, pearl. See Pennisetum glaucum

Millet, proso. See Panicum miliaceum

Milling, A., S80, S121

Milus, E., S121

Milus, E. A., S57, 124

Mimee, B., S257, S261

Min, K., S100

Minenkova, O., S199

Mingora, C., S134

Mint. See Mentha spp.

Minz, D., S92

Minzhao, Z., S84

Miranda Sazo, M. R., S262

Mireles, M., S67

Mireles, M. S., S4

miRNAs, artificial for engineering resistance against tospoviruses, S121

Misaghi, I. J., 794

Miscanthus spp.

Colletotrichum graminicola on, S260 phytopathogenic fungi associated with, S61

Misek, K., S243

Mitchell, F., S18

Mitchell, M. N., 805

Mitchell, P. D., S213

Mitchell, R., S121

Mitchell, T., S12

Mitchell, T. K., S2.4

Mitchell, T. R., S135

Mites

on citrus, $\mathrm{S} 186$

seaweed extract for control of on peppers, cucumbers, and Hass avocadoes, S126

Mith, O., S168

Mitkowski, N., S261

Mitra, A., S97, S2.3

Mitsuhashi, S., S173

Mittal, S., S174

Mitter, N., S12, S93, S121, S164

Miwa, E., S95

Mixon, J. T., S121

Miyasaka, S. C., S21, S124

Mizell, R. F., III, S170

Mizubuti, E. S., S75, S127, S166

Mizubuti, E. S. G., 1005

Mizukubo, T., 410

Mlakar, J., 1292

Mlsna, T., S193, S269

Mmbaga, M. T., S86, S90, S112, S121

Mock, R., S105, S195

Mock, R. G., S81, S142, S143

Moersfelder, J. W., S92

Moesch, M., S166

Mogrovejo, C., S133, S183

Mohammadi, E., S122

Mohan, K., S159

Mohan Kumar, S., S42, S56

Mohankumar, S., S159, S227

Molina, A. B., S122

Molina, M. F., S122

Molina Risco, M. D., S122
Molineros, J., S133, S183

Molnar, T., S25

Molnar, T. J., S123

Molyneux, R., S156

Momanyi, G., 1159

Momol, T. M., S74

Moncrief, I., S16, S81

Monfort, W., S170, S267

Monfort, W. S., S27, S38, S49

Monga, D., S30

Mongkolporn, O., S175

Moniliformin, Fusarium spp. on corn and, S18

Monilinia spp.

in China, S76

M. fructicola

Bacillus subtilis for control of, antifungal protein of a newly isolated strain, S204

baseline sensitivity and resistance mechanism of, S34

on cherry and peach, sterol demethylation inhibitor fungicides and, S2.6

on peach, scutellaria for control of, $\mathrm{S} 107$

selecting antagonists for postharvest control of, S81

on peach, management with biorational fungicides, S97

on stone fruits, spatial distribution and genetic population structure, $\mathrm{S} 221$

M. vaccinii-corymbosi, on blueberry, S176

Moniliophthora spp., on cacao, S272, S274

Mononchus spp. (predatory nematodes), food and microhabitat preferences of, S185

Monosporascus cannonballus, on melon, 794

Monteiro-Vitorello, C. B., 416

Montero-Ast·a, M., S123

Montes-Borrego, M., 250

Montpetit, J., S183, S257

Mony, S., S84

Moon, D., S121

Moore, A., S216, S219

Moore, G. A., S51

Moore, S., S99

Moore, S. R., S123, S161

Moorman, G., S74

Moorman, G. W., S23, S93, S258

Mora, F., S151

Moraes, W. B., S81, S82, S155

Morales, N. P., S250

Mordechai, S., S143

Moreira, E. N., S123, S155

Moreira, L., S255

Moreno-Velázquez, M., S123

Morey, K. J., S178

Morgan, D. J. W., 912

Morgan, D. P., S44

Mori, S., S177

Morid, B., S88, S112, S142

Morinda citrifolia (noni), microorganisms and antifungal properties associated with, S129

Moriones, E., 1191

Morishita, D., S126

Morita, S., S173

Moriwaki, J., S88

Morris, T. J., 1264

Morrison, J., S110

Morus spp. (mulberry)

Beauveria bassiana on, $\mathrm{S} 224$

Popcorn disease on, S35

Xylella fastidiosa on, S130

Moscardi, F., S224

Moscardi, M. L., S224

Moscoso-Ramírez, P. A., S124

Moslonka- Lefebvre, M., 392

Mosquitoes, Hyptis suaveolens essential oil for control of, S132

Mostert, D., S122

Mostrom, M., S244

Mota, A. A., S8

Motavalli, P., S62

Motomura, S. A., S124 
Mou, B., S46

Mountain pine beetle, Leptographium longiclavatum and, population genetic analysis of, S51

Moury, B., S24

Mouzeyar, S., 970

Mowery, P., S10

Moya, O., S254

Moyer, J. W., 147

Moyer, M., S14

Mozaffari, J., S160

MPVd. See Mexican papita viroid

MRLs. See Maximum residue limits

Mucharromah, S114

Mucor circinelloides, from noni, S129

Mueller, D., S242

Mueller, D. S., S15, S2.1

Mueller, E., S31

Mueller, T. A., S124

Mugo, H. M., S124

Mukankusi, C., S23, S124

Muklhongo, R., S89

Mulberry. See Morus spp.

Mulches

cellulase activity as a mechanism for suppression of phytophthora root rot in, 223

for management of onion bacterial diseases, S65

use for management of insects vectoring plant viruses, $\mathrm{S} 130$

Mulinti, P., S54

Mullens, T. R., S187

Mullins, D., S60

Mullins, D. E., S228

Mullis, S., S125

Mumford, J., S65

Munhoz, C. F., 416

Munkvold, G., S16, S22, S42

Munkvold, G. P., 1122

Munoz, A., S125

Munyaneza, J., S108

Munyaneza, J. E., S162

Murakami, S., S136

Murali, P. M., S10

Murley, V., S40

Murolo, S., S156

Murphy, J. A., S259

Murray, B. W., 68

Murray, T. D., S165

Murraya paniculata (orange jasmine), Candidatus

Liberibacter asiaticus in, S95

Musa spp. (banana)

Bactrocera musae on, S220

Banana bunchy top virus in cloning and sequence analysis of, S199 localization of within aphid vector, S20

Fusarium oxysporum f. sp. cubense on comparative transcriptome analysis of, S43 control of, S89

field resistance of selected cultivars, $\mathrm{S} 122$ impact on export and subsistence banana production, $\mathrm{S} 142$

vegetative compatibility group characterization of, S43, S122

Mycosphaerella fijiensis on, S133, S208

Pectobacterium chrysanthemi on, S15

Mushrooms

description of multiple species of edible, S33

hot water extract from spent substrate of for control of cucumber diseases, S136

Muskmelon. See Cucumis melo

Musser, F. R., S85

Musson, G., S125

Musson, G. H., S54

Mustard meal, fungal communities in strawberry roots and soils amended with, S173

Mutegi, C. K., S222

Muthomi, J., S172

Mwangi, E., S89

Mycelial compatibility groups (MCG), Sclerotinia sclerotiorum and aggressiveness of, S5

on canola, $\mathrm{S} 10$

Mycosphaerella spp.

for biological control of Japanese knotweed, S56

on eucalyptus, S140

M. fijiensis on banana

comparative genomic analysis of, S208

evaluating hybrids for resistance, S277 in Grand Nain, S133

M. graminicola on wheat

chromosome dynamics, genome evolution, stealth pathogenesis of, S208

fungicide mixing, resistance and, 1224

genetic differentiation at microsatellite loci among populations, 1251

genetic population structure of, S243

QTL for adult-plant resistance, 1209

M. nawae on persimmon, leaf wetness duration requirements of, 1346

M. polygoni-cuspidati, for biological control of Japanese knotweed, S95

Mycotoxins

in Asia and other countries (2009-2010), S222

Aspergillus niger on corn and peanut and, S135

climate change and, S222

corn ear molds and in North Dakota (2009), S244

and Fusarium spp

on corn, S18, S22

Microdochium spp. and, 960

on sugar beet, 1330

from sugar beet on wheat, 1338

Ochratoxin A, Aspergillus ochraceus biosynthesis of, $\mathrm{S} 48$

Mycoviruses, as biological control agents, S83, S169

Myers, K., S25, S261

Myrothecium roridum, for control of water lettuce, S131

Myrtaceae, Uredo rangelii on, S72

Myzus persicae (green peach aphid)

Beet yellows virus transmission and, S230

on ragweed in Hungary, S238

NAC-like transcription factor, and Burkholderia glumae on rice, $\mathrm{S} 268$

Nacro, S., S125, S130

Nadeau-Thibodeau, N., S262

Naeher, K., S222

Naidu, R. A., S4, S58, S67, S81, S85, S143, S144, S210, S229, 367, 1446

Mycosphaerella fijiensis on, $\mathrm{S} 277$

Nair, M. G., S120

Nakamura, S., S224

Nakhla, M. K., S125

Nam, M., S198

Namba, S., 567

Nan, Z., S102

Nancarrow, N., S53

Nancy, G. F., S94

Nandakumar, R., S268

Nandwani, D., S216

Nanoparticles. See Silver nanoparticles

Narla, R., S172

Nash, B., S211

Nasim, G., S238

Natamycin, production of by Streptomyces lydicus, $\mathrm{S} 107$

Natarajan, S., S126

Natilla, A., S126

National Clonal Germplasm Repository, sanitary status of Prunus spp. in, S134

National Plant Diagnostic Network, first detector training and education, S73

National Small Grains Collection mapping resistance to Phaeosphaeria nodorum in, 1301 rice blast resistance gene in, $\mathrm{S} 156$
National Weather Service, pecan scab predictions of, S138

Nauen, R., S235

Nava-Diaz, C., S98

Navaneetha, T., S145

Navarre, D., S230

Navas-Cortés, J. A., 250, 304

Navi, S., S83, S126, S2.4

Navi, S. S., S2.4

Navia, M., S254

Navie, S., S238

Navratil, M., 611

Nawkarkar, P., S61

Nazerian, E., S163, S174

NbSL11P protein, Potato virus $X$ resistance and, S36

NEAR. See Nicking enzyme amplification reaction

Neate, S. M., 687

Neave, S., S225

Nechet, K. L., S166

Neece, D., S25, S150

Needle nematodes, corn yield components affected by, S124

Neem oil extract

for Monilinia spp. on peach, S97

for Rhizoctonia spp. and Sclerotium hydrophilum on rice, $\mathrm{S} 11$

Negative exponentials, in modeling disease epidemics, different atmospheric conditions and, 1465

Negi, S., S117

Negrisoli, E., S8

Negron-Ortiz, V., S255

Neher, O. T., S126

Neily, W., S126

Nelson, A., S223

Nelson, B. D., S5, S144, S157

Nelson, D., S2.6

Nelson, M., S196, S197

Nelson, M. E., S106, S203

Nelson, R., S103

Nelson, R. J., 290

Nelson, S., S216

Nelson, S. D., S175

Nematodes. See also Heterodera spp.; Meloidogyne spp.

Bursaphelenchus spp.

B. cocophilus (red ring nematode), on oil palm, S254

B. xylophilus (pinewood nematode): distribution of in stem, xylem embolism development and, S3; on pine, Pseudomonas spp. and, S209; plant essential oils for control of, S137

community analysis for soil ecosystem health prediction, S187

on corn

comparison of methods for extracting, S2.1 distribution and abundance in Illinois, S110 yield components affected by, S124

on cotton

host resistance, $\mathrm{S} 265$

management of in multiple soil types with Telone II, S266

disease complexes with other plant pathogens, S209

Fusarium virguliforme on soybean and, S171

Globodera spp.

control and eradication of, S59

morphological and molecular characterization of populations from Oregon and Idaho, 480

management tools for through 2015, S266

methyl bromide alternatives and management of in strawberry, S129

Mononchus spp. (predatory nematodes), food and microhabitat preferences of, S185

new chemistry and $M i$ gene for management of, S265 
plant parasitic, teaching and learning identification of, S214

Pratylenchus spp.

on corn, comparison of methods for extracting, S2.1

on fruit trees in Iran, S175

on potato, Verticillium dahliae and, S209

on strawberry, crop rotation for suppression of, S160

sustainable management of, S225

viruses transmitted by, S209

Nemchinov, L. G., S126

Nemes, K., S126

Neoerysiphe spp., in ornamentals and herbs in Puerto Rice, S276

Neofabrea spp., on apple, S251

Neofusicoccum spp.

on blueberry, S194

on citrus, $\mathrm{S} 48$

Neonectria galligena, on apple, 135

Neonicotinoid insecticides

metabolism and stability of, S194

overview of, S233

recent developments in, $\mathrm{S} 233$

Neotyphodium spp.

collection of from tall fescue, S174

ergot alkaloid gene expression studies and, S54

Neovossia horrida (kernel smut), on rice, crop rotation, soil tillage and fertility and, S7

Nepal, A., S127, S245

Nepovirus sp., on melon, novel, in Japan, 316

Nerium oleander (oleander), Pseudomonas savastanoi on, IS53 transposase promoter and, S29

NETLOGO programming language, agent-based model of plant virus-host-vector interactions, S67

Networks, in plant epidemiology, 392

Neufeld, K. N., S127

Neumann, S., 105

Neural tube defects, fumonisin exposure and, S222

Nevárez-Portillo, G., S154

Neves Graca, R., S127

Newcomb, M., S127

Newman, M. A., S267

$\mathrm{Ng}, \mathrm{J} ., \mathrm{S} 69$

Ngugi, H., S80

Ngugi, H. K., 31, 42, S83, S128, S213, S222, 512

Nguyen, K., S54

Nguyen, L., S109

Nguyen, N., S118

Nguyen, T., S238

Nguyen, T. C., S97, S2.7

Ni, X., S128, S169

Nian, G., S102

Nibert, M. L., S101

Niblack, T. L., S110, S209, S2.3

Niche specialization, in soil and corn kernel Aspergillus flavus populations, 952

Nickel, Fusicladium effusum on pecan and, S193

Nicking enzyme amplification reaction (NEAR), in plant disease diagnostics, S215

Nicol, J. M., S226

Nicolas, P., 1045

Nicotiana spp. (tobacco)

Agrobacterium vitis on, phosphopantetheinyl transferase gene and hypersensitive response, $\mathrm{S} 23$

begomoviruses in, $\mathrm{S} 277$

$N$. benthamiana, Clavibacter michiganensis on, silencing of host basal defense responserelated gene expression and, 349

early season potyviruses in, S260

Iris yellow spot virus in, characterization of distinct strains, S12

as model to study systemic acquired resistance from Iris yellow spot virus, $\mathrm{S} 178$

monitoring behavior of cells by GFP labeling during infection process, S55
Phytophthora nicotianae on, Brassica juncea for control of, S73

Potato virus $Y$ in

in China, genetic diversity of, 377

overcoming host resistance during single-

host passages, S194

Pythium spp. on in hydroponic greenhouses S84

Tobacco mosaic virus in, control by PopW

from induced resistance in, 1202

Tomato golden mosaic virus in, S173

Tomato spotted wilt virus in, loss caused by in winter, 462

transgenic, broad spectrum resistance against species of different tospovirus serogroups, S140

Nielsen, D. M., 797

Nielsen, G. C., 960

Nielsen, K. A., S159

Nielsen, L. K., 960

Nieto-Angel, D., S3, S59, S98, S128, S133

Nigatu, L., S238

Nightshade. See Solanum sp.

Nikolaeva, E. V., S91

Nikolaeva, O. V., S47, S57, S88, S154, 778, 1052

Nilaparvata lugens (brown planthopper), on rice occurrence and management in Korea, S169 radar observation of migration of, $\mathrm{S} 83$

Nimbya alternantherae, on alligatorweed, S194

Ningnanmycin, for control of Sclerotinia homeocarpa and Colletotrichum cereale, on turfgrass, S111

Nischwitz, C., S125, S128, S129

Nishijima, K. A., S129

Nita, M., S56, S85

Nitromethylene nicotinoids, metabolism and stability of, S194

Niu, D., S129

Niu, D.-D., 1202

Nivalenol, Fusarium spp. on wheat and, 124

Njambere, E. N., S129, S211

Njau, P., S127

Njoroge, S. M. C., 523

Nock, J. F., S262

Noel, J., S176

Noel, J. T., S212

Noga, G., S13, S22, S77

Noling, J., S156

Noling, J. W., S129

Noll, L. W., S19

Non-host disease resistance, against multiple pathogenic fungi, DNAse signals from pathogen and, S68

Noni. See Morinda citrifolia

Noorda-Nguyen, K. M., S82

Noreña, C., S254

Norman, D., S130

Norman, D. J., S74, S145

Northern corn leaf blight. See Exserohilum turcicum

Northern rootworm. See Diabrotica barberi

Northern stem canker. See Diaporthe phaseolorum

Northwest Potato Variety Development Program (NPVDP)

new potato varieties with reduced fungicide requirements and, $\mathrm{S} 15$

screening for resistance against Pythium ultimum, S190

Norton, G. W., S161

Norton, R., S262

Nouri, S., S130

Noussourou, M., S60

Novinscak, A., S98, S130

Novy, R. G., S190

Nucleopolyhedroviruses

of beet armyworm, S225

use of as biological control agents in Australia, S224

Nuding, A., S20

Nunez, J., S130
Nunney, L., S130

Nuss, D. L., S273, S275

Nut gray necrosis. See Fusarium lateritium

Nutter, F. W., S63, S222, S274, S2.3

Nwe, L., S116

Nwilene, F., S130

Nwilene, F. E., S6

Oak. See Quercus spp

Oak, S., S74, S131

Oat blue dwarf virus (OBDV), coat protein expression strategy of, S47

Obando, C., S120

OBDV. See Oat blue dwarf virus

Oben, T. T., S131

Oberle, C. S., S192

Obligate pathogens, laboratory methods for evaluating, S229

Ocamb, C. M., 805

Occidiofungin, Burkholderia contaminans strain MS14 production of, S33

Ochoa Corona, F., S7, S9, S41, S44, S135, S217

Ochratoxin A

Aspergillus niger on corn and peanut and, S135

Aspergillus ochraceus biosynthesis of, S48

Ochs, J., S2.7

Ocimum basilicum (basil), Peronospora belbahrii

on colonization by Pseudozyma aphidis, S263

systemic acquired resistance inducers for control of, S120

O'Connell, N., S2, S49

Oculimacula spp., on Aegilops longissima, S165

Oda, C., S37

O’Donnell, C., S238

O'Donnell, K., 124

O’Donnell, K., S144

O’Donovan, J. T., S180

Odontoglossum ringspot virus (ORSV)

generation of antibody against from phage display library, S55

in orchids

elimination of, S187

molecular method for detection of, S26

Oerke, E., S72

Ofek, M., S92

Ogihara, Y., S94, S177

O'Gorman, D. T., S180

Oguntade, O., S131

Oh, C.-S., 935

Oh, I., S92, S165

Ohelo. See Vaccinium reticulatum

Ohm, H., 1278

Ohnishi, S., 575

Ohshima, K., S62

Ohtsu, R., S159

Oidium neolycopersici, on tomato, S254, S277

Oil palm. See Elaeis guineensis

Ojiambo, P., S131

Ojiambo, P. S., S127, S213, 451

Ok, C., S262

Oka, Y., S131

Okabe, I., S173

Okayama, H., 316

Okazaki, R., S6

O'Keeffe, T. L., S136

Okoth, S., S89

Oktarina, S., S114

Okubara, P., S117, S144

Okubara, P. A., S196

Okunowo, W. O., S131

Olanya, M., S98, S132

Olanya, O. M., 135

Olatinwo, R., S56

Olaya, G., S132, S166, S228, S229

Olea europaea (olive)

Pseudomonas savastanoi on, IS53 transposase promoter and, S29

Spilocaea oleagina on, sporulation dynamics and infection timing, S71 
Verticillium dahliae on, 304

Oleander. See Nerium oleander

Oleic acid, ICRISAT mini-core peanut germplasm

characterization and, S30

Olfert, O. O., S179

Oligoadenylate synthetase (OAS) pathway, broad spectrum virus resistance and, $\mathrm{S} 2.3$

Olineka, T., S134

Olivares-García, C., 304

Olive. See Olea europaea

Oliveira, A. L. M., 416

Oliveira, M. A., S8

Oliveira, R. B., S8

Oliver, J. E., S132

Olivera Firpo, P. D., S132

Olotuah, O. O., S132

Olpidium bornovanus, Monosporascus cannon-

ballus ascospore germination and, 794

Olsen, J., S63, S149, 1061

Olsen, M., S129

Olsen, N., S190

Olson, B. R., S132

Olson, H. A., 1373

Olson, J., S9

Olson, L., S245, S2.6

Olson, L. K., S2.7

Olson, M. E., S69

Olson, S. M., S136

Olson, T. N., S91

Omdal, D., S32

Onasanya, A., S130

Onasanya, R. O., S6

Oncidium spp., Dickeya sp. on, S29

O’Neal, M., S153

O'Neil, W., S122

On-farm research, for implementation of methyl

bromide alternatives, $\mathrm{S} 45$

Ong, K., S48

Ongena, M., 996

Onion. See Allium cepa

Ooshiro, A., S173

Oostendorp, M., S133, S160

Oosterhof, J., S133

Ophiognomonia clavigignenti-juglandacearum,

on butternut, S20, S257, S262

Ophiostoma spp.

associated with bark beetles infesting conifers, S204

western oak bark beetle in oak in California and, S249

Ophisphaerella korrae, on bermudagrasses, S177

Ophraella communa, for control of ragweed, S185

Ophyostoma stenoceras, on rose, S59

Opperman, C. H., S42

Orange. See Citrus sinensis

Orange jasmine. See Murraya paniculata

Orange peel oil, for Aleurocanthus woglumi on citrus in Brazil, S28

Orange spotting disease of oil palm. See Coconut

Cadang-cadang viroid

Orapa, W., S219

Orchids

Acidovorax cattleyae on, S175

Cymbidium mosaic virus in, elimination of $\mathrm{S} 26, \mathrm{~S} 187$

Dickeya sp. on, S29

molecular method for detection of viruses in, S26

Odontoglossum ringspot virus in, S55, S187

Ordoñez, M. E., 870

Organic farming

disease severity and yield potential of rice cultivars in, S270

host plant and substrate shifts in soil microbial communities and, S32

production of healthy seed potatoes and, S31

profile of Pythium spp. in certified fields, S4

pyrosequencing to reveal influence of on

bacterial communities and plant health, S102 seed meals for disease control in apple orchards, S117

tomato, effect of cover crops on nematode population density, S120

Ornamental plants, in Kerman Province, Iran,

fungal diseases of, $\mathrm{S} 13$

Orobanche spp. (broomrape)

management of, S239

plant-plant and plant-microbe interactions in rhizosphere and, S233

in tomato, strigolactone and resistance against, 213

Orozco-Santos, M., S3, S133

Orquera, G., S133, S183

Orseolia oryzivora, on rice, S130

Ortega-Beltran, A., S133, S250

Ortiz, B., S123

Ortiz-Ribbing, L. M., S134

Oryctes rhinoceros, management of, S219, S220

Oryza sativa (rice)

African rice gall midge on, $\mathrm{S} 130$

Bipolaris oryzae on, deficiency in silicon uptake and, 92

brown planthopper on

occurrence and management in Korea, S169 radar observation of migration of, $\mathrm{S} 83$

Burkholderia spp. on

$B$. glumae: management with beneficial $B$. strains, S270; melanin-like pigments and virulence of, S266; molecular and genomic studies of, S266; NAC-like transcription factor and, S268; quorum sensing in, S264; silver nanoparticles for control of, S36; in Texas, S205

suppression by pretreatment with various chemicals, S166

disease resistant cultivars, S204

Fusarium spp. on

F. fujikouri: hot water treatment for seed disinfection and germination, S155; resistance to prochloraz, S91

F. moniliforme and Burkholderia glumae, silver nanoparticles for control of, S36

$F$. verticillioides, association between isolates from, S88

Gaeumannomyces graminis on, mode of infection, S202

gene flow and herbicide resistance in, S236

Gibberella fujikuroi on, sodium hypochlorite for control of, S165

Helminthospoirum oryzae on, Pseudomonas

fluorescens SP007s for control of, S146

inverse response of two genes against bacterial

blight of, S182

Magnaporthe oryzae on

chitinase gene and disease resistance, S100

determination of geographic origin of different pathovars, S182

ethylene overexpression for resistance against, S71

GATA factor and virulence, S2.8

influence of weather factors on, S52

inhibition by Sarocladium oryzae, S166

Lysobacter enzymogenes for control of, S116

mapping quantitative trait loci for resistance, 176

molecular mapping of resistance genes in cultivar Xiangzi 3150, 620

mutated lines showing improved resistance to, $\mathrm{S} 148$

OsERF9, biotic and abiotic stress responses and, $\mathrm{S} 108$

$\mathrm{PaC}$ mediated adaption to alkaline $\mathrm{pH}$ and, $\mathrm{S} 140$

PCG1 gene and pathogenesis of, S198

phenomics of, S149

$P i-b$ resistance gene and, $\mathrm{S} 156$

$P i$-ta locus and, S82

reactive oxygen species, MoHYRl and,
S76, S273

rhizobacteria in defense of, S5

small RNAs and biosynthetic genes of, pathogenicity and, S150

zinc-finger effectors, plant cell death and immunity and, $\mathrm{S} 108$

Magnaporthe spp. on, mode of infection, S202 organic production systems for, S270

Rhizoctonia spp. on

response of to plant extracts, $\mathrm{S} 11$

$R$. solani: chitinase gene and disease resistance, S100; Chromolaena odorata extract for control of, 231; ethylene overexpression for resistance against, S71; genetic basis of resistance, $\mathrm{S} 170$ inhibition by Sarocladium oryzae, S166; B. subtilis for control of, S204; suppression with brassica biofumigation crops, S204; testing mega-varieties for susceptibility, S112

Rice stripe virus in, S205

Sarocladium oryzae on, S166

Sclerotium hydrophilum on, response of to plant extracts, S11

smuts on, crop rotation, soil tillage and fertility and, S7

Southern rice black-streaked dwarf virus in, S194

in tropical and subtropical Asia, as framework for analysis of risk factors for crop health under global change and agricultural shifts, 696

USDA-APHIS quarantine program for, S114

Xanthomonas oryzae on

copper and, S207

genetic background of $\mathrm{Xa} 7$ resistance gene and, S188

Osborne, L., S67

Osborne, L. E., S87, S244, S2.3, S2.4

Osei, M., S60

Osei, M. K., S228

OsERF9, Magnaporthe oryzae on rice and, S108

Oshima, K., 567

Osler, R., S255

Osman, F., S4, S134

Osman, F. A., S61

Osorno, J. M., S138

Ospina-Giraldo, M. D., S134

Osswald, W., S40

Osterbauer, N., S134

Ostriniae furnacalis (Asian corn borer), Trichogramma dendrolimi for control of, S39

Ostry, M. E., 404

Osuntoki, A. A., S131

Otani, H., S136

Otrosina, W., S135

Otto, K., S17

Otuka, A., S159

Oudemans, P., S143

Ouedraogo, L., S193

Outwater, C. A., S188

Ouyang, P., S135

Overstreet, C., S266

Oviposition, in white fly parasitoids, S185

Owens, K. J., S125

Owens, R. A., S181

Ownley, B. H., S2, S75, S109, S121, S184

Oxalate oxidase, and resistance against Sclerotinia minor on peanut, 786

Oxalic acid, Sclerotinia sclerotiorum pathogenicity and, S86, S104

Oxidative burst, Induced systemic resistance against Botrytis cinerea and, 768

Oxylipins, as signals in cross-kingdom communications regulating disease progression, S230

OxyR, Pantoea stewartii subsp. stewartii on corn and, S23

Oxytropis spp. (locoweeds), Undifilum spp. on comparison of Undifilum DNA and swainsonine content, $\mathrm{S} 2$ 
detection and localization of, S152

new swainsonine-producing species, S14

proteomic analysis of, $\mathrm{S} 104$

Özaktan, H., S65

Ozias-Akins, P., S66

Ozkilinc, H., S135, S171

Pachybasin, from Trichoderma harzianum, S106

Packaging. See Solid wood packing material

Paclobutrazol, and demethylation inhibitor fungi-

cides for Sclerotinia homeocarpa on turfgrass, S25

Padasht, F., S112

PaDIL, overview of, S218

Paecilomyces lilacinus, for control of Meloidogyne incognita, 92

Paenibacillus polymyxa, and Botrytis cinerea on grape, S71

Paetzold, L., S194

Paez, P. A., S71

Pagliaccia, D., S135

Paichongding, metabolism and stability of, S194

Pájtli, É., S136

Pak choy. See Brassica rapa subsp. chinensis

Pale cyst nematode. See Globodera pallida

Palencia, E. R., S135

Palkovics, L., S136

Palloix, A., 154

Palm. See Cocos nucifera; Elaeis guineensis;

Phoenix spp.

Palm, M. E., S95

Palmateer, A., S278

Palmateer, A. J., S26, S29, S175

Palmer, C., S181

Palmieri, M., S210

Palmucci, H. E., S64, S136

Palomares-Rius, J. E., 1168

Palou, L., S124

Palukaitis, P., S198, S199

Palumbo, J. D., S136

Pan, H., S201

Pan, J., S53

Pan, S., 620

Panaccione, D. G., S53, S54

Panama disease. See Fusarium oxysporum f. sp. cubense

Pande, S., S226

Pandey, A. K., S139

Pandian, K., S162

Pandian, V., S58

Pandora neoaphidis, on soybean, S153

Panicle blast. See Magnaporthe oryzae

Panicle blight. See Burkholderia gladioli

Panicum spp.

P. miliaceum (proso millet), Acidovorax avenae subsp. avenae on, S198

$P$. virgatum (switchgrass)

foliar diseases of in Mississippi, S61

incidence and prevalence of fungal pathogens on, $\mathrm{S} 184$

Puccinia emaculata on, S16, S174

Sebacina vermifera and drought tolerance, S60

Panijel, M., S136

Pannecoucque, J., 996

Panonychus citri, on citrus, S186

Pantoea spp.

$P$. agglomerans

on cotton, transmission by brown stink bug, S119

quorum sensing and, S136

strain E325: against Erwinia amylovora on apple flower stigmas, S146, 1234; monitoring environmental impact and behavior in orchards, S19

strain EH252, for control of Erwinia amylovora on pear, 113, 299

$P$. ananatis, on onion, S274

applied genomics to understand and improve biocontrol activity of, S232
P. stewartii subsp. stewartii, on corn oxidative stress response, virulence, host colonization and, S23

PCR primers for detection of, S16

P. vagans strain C9-1, for control of Erwinia amylovora on pear, 113, 299

Pantoja, M. B., S166

Papaya. See Carica papaya

Papaya leaf-distortion mosaic virus (PLDMV), in papaya, S198

Papaya ringspot virus (PRSV)

deletion of $\mathrm{N}$ terminus of larger coat protein of, S35

in papaya, $\mathrm{S} 198, \mathrm{~S} 237$

Pappu, H. R., S5, S12, S30, S93, S105, S109,

S121, S162, S164, S172, S178, S182

Parac, E. A., S227

Paracoccus marginatus (papaya mealybug) on brinjal, S162 on papaya, biological control of, S85

Parada, R. Y., S136

Paradornuwat, A., S44

Pararetroviruses, in dahlia, promoter elements from, S5

Pardo, J. M., S253

Pardyjak, E., S112

Parejko, J. A., 1481

Paret, M. L., S136

Parikh, P. D., S139

Park, E., S141

Park, H., S165

Park, I., S137

Park, J., S74, S100, S137, S208, S245

Park, K., S91, S234

Park, M., S137

Park, S., S36, S92, S137

Park, S.-Y., 523

Park, Y., S230

Parke, J. L., S20, S101, S137

Parker, B. O., S215

Parker, S. R., S196

Parkin, I., S67

Parks, E. J., 147

Parkunan, V., S138

Parnell, S., 1184

Parrella, M. P., S250

Parsley. See Petroselinum crispum

Parthenium hysterophorus, sustainable manage-

ment of under changing climate, S238

Partridge-Telenko, D. E., 786

Paschke, M., S23

Passiflora edulis (passion fruit)

Cladosporium spp. on, S174

phytoplasmas on, S272

Xanthomonas axonopodis pv. passiflorae on, 416

Pastor-Corrales, M. A., S138

Pastures, use of microbes in bioprotection of, S224

Pastushock, G., S165

Patel, A., S164

Patel, A. V., S80, S182

Patel, J. S., S2.7

Patel, N., S116, S138, S231

Pathogen-associated molecular patterns (PAMP)

Arabidopsis CRT1 family and, S113

Arabidopsis-Pseudomonas syringae interaction and, S207

Candidatus Liberibacter asiaticus flagellin protein and, S206

defense response of Anthurium andraeanum against Radopholus similis and, S113

early activation of defense genes in kumquat by the citrus canker pathogen and, S51

Patil, V. B., S138

Patterson, C., S93

Patterson, H. A., 492

Paul, P., S50, S170, S191, S223, S242

Paul, P. A., 16, S31, S48, S160, S195, S221, 1122

Paulitz, T. C., S4, S144, S161, 1481

Paulsen, I., S117
Paulsen, I. T., S231

Pautasso, M., 392, 1024, 1032

Pavan, W., S140, S221

Paveley, N. D., 1224

Payne, A., S138

Payne, A. F., S267

Payne, G. A., S222, 797

Payton, M., S155

Paz, Z., S208

PBNSPaV. See Plum bark necrosis stem pittingassociated virus

PBNV. See Peanut bud necrosis virus

PCG1 gene, Magnaporthe oryzae pathogenesis and, S198

Pcg2 gene, from Magnaporthe oryzae, S187

PCV. See Peanut clump virus

Peña, A., S55

Pea. See Cicer arietinum; Pisum sativum

Pea enation mosaic virus (PEMV), in pea, S182, $\mathrm{S} 2.5$

Pea mosaic virus (PeMV), in pea, S2.5

Pea streak virus (PeSV), in pea, S2.5

Peach. See Prunus persica

Peach latent mosaic viroid (PLMVd), in stone fruit trees, detection of, $\mathrm{S} 105$

Peachey, E., S138

Peak, nutritional formulation for suppression of plant diseases, S77

Peanut. See Arachis hypogaea

Peanut bud necrosis virus (PBNV) in tomato, S58, S210 in vegetables, in India, 367

Peanut clump virus (PCV), Polymyxa graminis on cereals and, 1149

Peanut Rx, for management of peanut diseases, S56

Pear. See Pyrus pyrifolia

Pearce, T. L., S139

Pearl millet blast. See Pyricularia grisea

Pearsaul, D., S132

Pecan. See Carya illinoensis

Pectin methylesterase, Phytophthora infestans on potato and, S134

Pectobacterium spp.

P. atroseptica, on potato, S187, S193

$P$. carotovorum

3-hydroxy-2-butanone pathway for virulence of, S114

on lettuce, Salmonella enterica and, S96

on wild potato, resistance to, 205

P. chrysanthemi, on banana, S15

Pectolyase, Salmonella enterica on tomato and, S212

PeCTV. See Pepper curly top virus

Pedersen, D. K., S31

Pedersen, J. F., S243

Pedersen, P., S132

Pederson, J., S2.6

Pedley, K., S40, S220

Pedley, K. F., S139, S141, 535

Peduto, F., S139, S179

Peeden, K., S108, S139

Peeden, K. A., S173, S178

Peever, T., S135, S171

Peever, T. L., S46, S77, S127, S2.2

Pegues, M., S68

Peinado, S. A., S139

Peiqian, L., S15

Pelargonium extract, for Rhizoctonia spp. and

Sclerotium hydrophilum on rice, $\mathrm{S} 11$

Peltier, A. J., S245

PeMV. See Pea mosaic virus

Pena, J. E., S77

Peng, G., S77

Peng, J., S139, S140

Peng, K., S106, S108, S109, S248, S251

Peng, Y., S140, S187, S198

Peng, Z., S140

Pengfei, Z., S84

Penicillin, Candidatus Liberibacter asiaticus and, 1097 
Penicillium spp.

on citrus, postharvest evaluation of chemicals as inducers of resistance against, S124

$P$. expansum, on apple and pear, $\mathrm{S} 182$

$P$. solitum, on apple, S141

Pennisetum spp.

$P$. clandestinum (kikuyugrass), genetic structure of Magnaporthe grisea populations associated with, 85

P. glaucum (pearl millet), Pyricularia grisea on, S164

Pentalonia nigronervosa, localization of Banana bunchy top virus within, S20

Penthiopyrad

for Colletotrichum cereale, S261

for control of Sclerotium cepivorum on onion, S52

partitioning and efficacy in apple leaves, S142 uptake and translocation in wheat leaves, S141, S142

Peper, A., S93

Pepino mosaic virus (PepMV)

engineering infectious cDNA clone of, S199

in tomato

deep sequencing for identification of, S106 generation of infectious clones, S46

genetic and biological isolate variability, S70

Pepper. See Capsicum annuum

Pepper curly top virus (PeCTV), quantification and differentiation in mixed viral infections, S139

Pepper yellow dwarf virus (PeYDV), quantification and differentiation in mixed viral infections, S139

Peppermint. See Mentha spp.

Perception of risk, rational decision making and, 654

Peregrinus maidus (corn planthopper), Maize mosaic virus and fitness and wing morphology, S72

Pereira, S. C., 92

Peres, N. A., S140

Perez, C. A., S140

Perez-Hernandez, O., S2.8

Perim, L., S8

Peronospora spp.

$P$. belbahrii, on basil

colonization by Pseudozyma aphidis, S263 systemic acquired resistance inducers for control of, S120

$P$. farinosa, on spinach, characterization of new races and strains of, S52

Peros, J., S14

Perotin, B., S142

Perry, K. L., S189

Persea americana (avocado)

Colletotrichum gloeosporioides on, imazalil

for control of, S128

Phytophthora cinnamomi on, S135, S278

Raffaelea spp. on

R. canadensis, $\mathrm{S} 50$

R. lauricola, $\mathrm{S} 78$

seaweed extract for control of thrips on, S126

Persimmon. See Diospyros spp.

Perumal, R., S140

Pestalotiopsis $\mathrm{sp}$

on mangosteen, S89

on persimmon, in Brazil, S17

P. psidii, on Brassica rapa, $\mathrm{S} 37$

Pestnet diagnosis service, S218

PeSV. See Pea streak virus

Peter, K., S141

Peter, K. A., S86, S183

Peters, J., 1365

Peterson, G., S40, S220

Peterson, G. L., S141

Pethybridge, S., S2.2

Pethybridge, S. J., S139, S141, S162, 640, 1112

Petroselinum crispum (parsley)
Pseudomonas viridiflava on, S116

rapid identification of $P$. syringae $p v$. corian-

dricola and $P$. syringae pathovars on, 847

Petzoldt, C. H., S1

PeYDV. See Pepper yellow dwarf virus

Pfeiffer, D., S60

Pfeiffer, D. G., S228

Pfender, W. F., 644

PFLP. See Plant ferredoxin-like protein

Pflueger, V., S145

Phaeocryptopus gaeumannii, on Douglas fir, 583

Phaeoisariopsis griseola, on common bean, S278

Phaeomoniella chlamydospora, on grape, S42

Phaeosphaeria nodorum, on wheat

association mapping of resistance in USDA

National Small Grains Collection, 1301

flag leaf-based foliar fungicide application thresholds for, S191

new QTL for resistance to, 1278

Phakopsora spp.

diagnostic quantitative PCR assays for, S157

P. pachyrhizi (Asian soybean rust)

on kudzu, S199

on soybean: aerial application for control of, S8; extended latent infection period with, S269; identification of resistance genes in Hyuuga soybean, 535; near isogenic lines, resistance and, S58; neural networks for pattern recognition in, S123; penetration and establishment of, 894; silicon amendment and resistance to, S257; virus-induced gene silencing and, S139

on soybean, archaeophytopathology of, S244

Phalaenopsis spp.

Acidovorax cattleyae on, S175

Odontoglossum ringspot virus and Cymbidium mosaic virus in, $\mathrm{S} 187$

Phaseolinone, Macrophomina phaseolina and, S11

Phaseolus spp. (bean)

Aspergillus flavus on, aflatoxin production and, S23

Colletotrichum lindemuthianum in, genetic analysis of resistance to, 757

Cucumber mosaic virus in, novel satellite

RNA associated with, S130

Didymella fabae on, $\mathrm{S} 135$

disease incidence in Angola, S277

disease prevalence and distribution in $\mathrm{Ne}$ -

braska, S70

Fusarium spp. on

F. avenaceum and Rhizoctonia solani, fungicide seed treatments for, S30 inheritance of resistance, $\mathrm{S} 124$

F. oxysporum f. sp. phaseoli, new virulence groups in, 470

P. lunatus (lima bean), Phytophthora phaseoli, gene expression during infection, S94, S273

Phaeoisariopsis griseola on, S278

Phytophthora spp. on

P. capsici, S43

$P$. phaseoli, gene expression during infection, S94, S273

Pseudomonas syringae on pv. phaseolicola, S202, S242 pv. syringae, $\mathrm{S} 242$

Pythium spp. on, S69, S259

Rhizoctonia solani on, S159, 996

Sclerotinia sclerotiorum on, Trichoderma spp. for control of, S109

Uromyces appendiculatus on, S138, S245, S2.7

P. vulgaris (snap bean)

pathogens of, chloride salt and changes in tap root calcium partitioning, S26

Phytophthora capsici on, S43

Pseudomonas syringae pv. phaseolicola on, copper resistance in, $\mathrm{S} 202$

Pythium spp. on, S69, S259 white mold on, search for resistant cultivars, S278

Xanthomonas spp. on

$X$. axonopodis pv. phaseoli, S242, 425

$X$. fuscans subsp. fuscans, 425

Phelipanche spp., in tomato, strigolactone and resistance against, 213

Phellinus spp., on ironwood, S216

Phenacoccus solenopsis (Solenopsis mealybug), on brinjal, S162

Phenazine-1-carboxylic acid, Streptomyces scabies on potato and, $\mathrm{S} 9$

Phenazines, biological control of Rhizoctonia solani on bean and, 996

Phenolic acids, Fusarium graminearum and, 929

Pheromone trap catches, bean bug on soybean and, S48

Philmus, B. J., S64

Phipps, P. M., 786

PhiRSS1, and virulence of Ralstonia solanacearum, $\mathrm{S} 2$

Phoenix spp.

$P$. canariensis (Canary Island date palm),

Fusarium spp. on, detection in Nevada, S125

Rhynchophorus ferrugineus on, $\mathrm{S} 3$

P. dactylifera (date palm), Rhynchophorus ferrugineus on, S3

Phoma spp.

heterothallism in, S2.2

P. ligulicola var. inoxydabilis, on pyrethrum,

1112

P. sclerotioides, on alfalfa, S29, 594

Phomopsis spp.

$P$. amaranthicola, for control of waterhemp and redroot pigweed, $\mathrm{S} 134$

on blueberry, S99

on grape, identification of new, S56

$P$. sclerotioides, in cucurbit field soil, detection of, S56

on soybean

identification of accessions with resistance against, $\mathrm{S} 103$

stink bugs and, S85

widespread latent and pathogenic infection in Minnesota, S243

on sunflower, S115

$P$. viticola, on grape, $\mathrm{S} 221$

Phosphite, Fusicladium effusum on pecan and, S17

Phosphoglucose isomerase, Epiphyas postvittana and, S70

Photinia $\times$ fraseri, Entomosporium $\mathrm{sp}$. on, drench and foliar fungicides for control of, S68

Phyllactinia guttata, on almond, S157

Phyllosphere, E. coli O157:H7 in, S212

Phymatotrichopsis omnivora, multi-gene based

detection and identification of, $\mathrm{S} 9$

Physoderma maydis, on corn, S93

Phytoalexins

hypovirulent Rhizoctonia spp. and, 828

Induced systemic resistance against Botrytis cinerea and, 768

Phytomonas staheli, on oil palm, S253

Phytophthora spp.

algicides for in infested water, S119

on blueberry, S167

CANARY for rapid detection of, S106

P. capsici

differences in virulence of global isolates of, S63

diversity and fungicide resistance of, S79

fluopicolide-resistant, risk assessment of, S110

genetic structure of populations, S149, 1061

global phenotypic variation in, S63

herbicide-resistant, cesA3 mutations and, S34

in irrigation water, management of, S100

on multiple new species in Brazil, S43 
on pecan, $\mathrm{S} 159$

on pepper: biofungicides as transplant and soil treatment, S250; co-infection with Meloidogyne incognita and, S176, fungicides for management of, S115; Revus drip application and, S94

on rose, Martelella endophytica for control of, plant growth promotion, resistance induction, nitrogen fixation and, S15

on squash, Revus drip application and, S94

on tomato, plant activators and salinityinduced predisposition, S147

on watermelon, sources of resistance to, S94 zoxamide and, 1104

P. cinnamomi

on avocado, S135, S278

on cranberry, Chromobacterium sensu lato

for biological control of, S168

on mulches, cellulase activity for suppression of, 223

P. colocasiae, on taro, screening for resistance, $\mathrm{S} 21$

community-based stream monitoring program for, $\mathrm{S} 247$

P. cryptogea, on floriculture crops in N.C. greenhouses, 1373

P. drechsleri, on floriculture crops in N.C.

greenhouses, 1373

of forests, website for, S137

gene trees vs. species trees for resolving clade

$1 \mathrm{C}$ phylogeny, S16

$P$. infestans

aerial dispersal as component of late blight decision support system, S263

custom transcription factors for manipulation of gene expression in, S7

hybridization of to unknown related species, S62

on potato: in 2010 following 2009 epidemic, S41; Andean soils from Ecuador for suppression of, S182; caspase 3-like activity and, S52; characterization of from suppressive soil in Ecuador, S133; characterization of isolates (2010), S261; coinfection of by two viruses, S25; pectin methylesterase gene expression during infection, S134; transcriptome dynamics in response to, S58; in Wisconsin in 2009 and 2010, S162; xyloglucanspecific endoglucanase inhibitor proteins and, S85

on potato (wild), Rpi-blbl gene of and resistance, S69, 263

on Solanum betaceum, S120

sporangia survival, meteorological factors and, S132

on tomato: in 2010 following 2009 epidemic, S41; characterization of isolates (2010), S261; coinfection of by two viruses, S25; control using high tunnels, S79; fungicide resistance, pathogenicity, and virulence, $\mathrm{S} 246$

on wild potato, Rpi-blb1 gene of and resistance, S69, 263

on intensive crops in Argentina, S136

in irrigation water, identification of, S110

on Japanese iris, S6

P. kernoviae, sporulation potential on selected hosts, S191

Lucid key to, S153

multiples detection of, S18

$P$. nicotianae

on Catharanthus roseus, S266

on pineapple, $\mathrm{S} 167$

on tobacco: Brassica juncea for control of

S73; components of resistance, S98

in nurseries, greenhouses, and landscape

plantings in Indiana, S244

in nursery irrigation water runoff, S74

P. obscura, on Kalmia latifolia, S65
P. palmivora

on oil palm, S253, S254

on papaya, disease tolerance gene identification, S82

on pepper, control by microbial and chemical fungicides, S74

$P$. phaseoli, on lima bean, gene expression during infection, S94, S273

$P$. plurivola, in European beech

citricolin effector protein localization in roots, $\mathrm{S} 40$

potassium phosphite and, S40

on pumpkin and watermelon, molecular charac-

terization and fungicide sensitivity, S268

$P$. ramorum

on California bay, rhododendron, and camellia, S177

on canyon live oak, S8

effect of salinity on viability and infectivity, S146

inoculum density effects on infection of, S274

in Italian forests, $\mathrm{S} 182$

on ornamental and native plants: migration within North America and Europe, 166; risk analysis for, S166

problems preventing entry and spread of, S218

queries for detection of in simulated metagenomes, S50

real-time and nested PCR for detection of, S38

research at National Ornamentals Research

Site at Dominican University of California, S85

in soil, management with Trichoderma asperellum, $\mathrm{S} 191$

sources of in Sammamish waterway, S32

spatial sampling for detection of outside of eradication zone, 725

spread to water, soil, and vegetation outside nursery in Washington, S32

on star jasmine, S134

transmission of in California oak woodlands, influence of forest type on, 492

utilization of dead leaf litter in aquatic systems and, S8

on Viburnum tinus and Rhododendron sp., test system for quantifying inoculum in runoff from infected plant roots, 1457

in vitro baiting assay for recovery of from waterways, S131

zoospore germination inhibition by chemical fungicides, S248

rapid diagnostic tools for, $\mathrm{S} 153$

P. rubi, on raspberry, $\mathrm{S} 248$

screening of world collection for viruses, S116

severity risk spatial model for, $\mathrm{S} 90$

P. sojae

Avr genes of, S190

effector proteins of, S230

on soybean: avrla gene and, S246; comparison of genes underlying two QTL conferring partial resistance to, S186; mapping QTL conferring resistance to, S186; new race of in Argentina, S64; QTL conferring partial resistance, S100; Rps gene loci and, S66

in streams in Virginia, S74

Streptomyces spp. for control of, S180

survival of in irrigation water, temperature and, S69

survival of in simulated aquatic system at different $\mathrm{pH}$ levels, $\mathrm{S} 93$

volunteer stream monitoring for in Washington, $\mathrm{S} 48$

Phytoplasmas. See also Candidatus spp.

on almond, peach and pear, S172

on grapevine, new approach to management of, S156 on guacime causing witches' broom, S255

$i$ PhyClassifier for identification and classifi-

cation of, S214

on passion fruit, $\mathrm{S} 272$

plant hormones as biomarkers of early infection, S273

on potato, $\mathrm{S} 44$

on purple coneflower, $\mathrm{S} 139$

on tomato, S272

Phytopythium spp., on intensive crops in

Argentina, S136

PI-3-P, entry of oomycete, fungal and insect effectors into host cells and, S230

Pi47 and Pi48 genes, and resistance against Magnaporthe oryzae, 620

$P i-b$ resistance gene, Magnaporthe oryzae on rice and, S156

Pichia guilliermondii, glucanase and chitinase from, S66

Picton, D. D., S125

PidS and PidR, Burkholderia glumae on rice and, S88

Pierce, B., S141

Pierce's disease. See Xylella fastidiosa

Pierson, E., 1285

Pierson, E. A., S45

Pierson, L. S., S45

Pigweed. See Amaranthus spp.

Pil-Chp chemosensory-like operon, Xylella

fastidiosa on grape and, S10

Pilkington, L. J., S151

Pils, J. R., S141, S142

Pimenta, R. S., S81

Pineapple. See Ananas comosus

Pineapple mealybug wilt associated viruses (PMWaV)

detection of, S42

in pineapple, in Hawaii, S229

Pineda, B., S253

Pinewood nematode. See Bursaphelenchus xylophilus

Ping, Y. C., S55

Pinson-Gadais, L., 929

Pinus spp.

\section{Armillaria spp. on, S258}

blackstain root disease of, $\mathrm{S} 135$

Bursaphelenchus xylophilus on, Pseudomonas spp. and, S209

Cronartium ribicola on, chitinase gene and resistance against, 904

Dothistroma septosporum on, sexual reproduction and gene flow of in British Columbia, 68

Fusarium circinatum on, S174

Gibberella circinata on, S167

Grosmannia clavigera on, S188

mountain pine beetle and Leptographium

longiclavatum on, S51

Sphaeropsis sapinea sensu lato on, 334

western corn rootworms on, S2.4

white pine needle disease of in eastern Canada, S260

Pio-Ribeiro, G., S166

PIPO (Pretty Interesting Potyviridae ORF), interaction of with maize protein, $\mathrm{S} 107$

Pirahesh, S., S142

Pisani, C., S142

Pistia stratioles (water lettuce), Myrothecium roridum for control of, S131

Pisum sativum (pea)

Asochyta rabiei on, detection of fungicide resistance and, S62

Chickpea chlorotic stunt virus in, S205

Fusarium graminearum on, gene expression during root infection, S35

new broad-spectrum fungicide for, $\mathrm{S} 115$

Pea enation mosaic virus in, $\mathrm{S} 182$

Pseudomonas syringae on, detection of in seeds, S36

RNA-seq based research on interaction with 
Sclerotinia sclerotiorum, S2.9

Soybean dwarf virus in, S176

$\mathrm{Pi}$-ta gene locus, resistance to Magnaporthe oryzae and, $\mathrm{S} 82$

Pitman, T., S134

Pityophthorus juglandis (Walnut twig beetle), Geosmithia morbida and, S55, S138

Planococcus ficus, on grape, mating disruption for control of, S120

Plant Biosecurity Short Course, overview of, S38

Plant defense activators, chemical and gene technological approaches for, S233

Plant Disease and Insect Clinic, social media sites at, S109

Plant ferredoxin-like protein (PFLP), in Arabidopsis thaliana, hypersensitive response (HR) and, 741

Plant growth regulators, and demethylation inhibitor fungicides for Sclerotinia homeocarpa on turfgrass, S25

Planthopper, small brown. See Laodelphax striatellus

Plantwise Initiative, detection of new and emerg

ing pests and diseases through, S73

Plasma technology, for control of seedborne diseases, S264

Plasmids, from Erwinia amylovora in orchards in Washington and Oregon, S26

Plasmodiophora brassicae on canola, S77, S179 on pak choy, 1424

Plasmopara spp.

$P$. halstedii on sunflower characterization of two types of resistance to, 970 emergence of new virulent strains, S2.3

$P$. viticola on grape, decision support system for management of, S24

PLDMV. See Papaya leaf-distortion mosaic virus

Pleochaera polychaeta, on mesquite, S129

Plett, J., S230

PLMVd. See Peach latent mosaic viroid

Ploetz, R., S78, S142, S277

PLRV. See Potato leafroll virus

Plum bark necrosis stem pitting-associated virus (PBNSPaV), in stone fruit trees, detection of, S105

Plum pox virus (PPV)

characterization of $\mathrm{W}$ isolate, $\mathrm{S} 117$

eradication programs in U.S. and Canada, S222

M strain, S122

in Prunus spp.

analysis of epitope structure of coat protein, 611

LAMP assays for detection of, S58

molecular, ultrastructural, and biological characterization of isolates from Pennsylvania, 627

molecular epidemiology of in Japan, 567

sequence variability, recombination analysis, and specific detection of the W strain, 980

spatial dynamics of, S63

sampling and detection efficiencies of U.S and Canadian eradication programs, S2.3

Plutella xylostella (diamondback moth)

catharidin for control of, S84

on collard greens, biorational insecticides used for, S53

Plyler-Harveson, T., S159

PmCh4B gene, in white pine, and resistance against Cronartium ribicola, 904

PMWaV. See Pineapple mealybug wilt associated viruses

PNRSV. See Prunus necrotic ringspot virus

Poa spp. (bluegrasses)

Colletotrichum cereale on, S259

Waitea circinata on, S35

Pochonia chlamydosporia var. catenulata, for control of Meloidogyne incognita, 92

Poculum sp., isolated from warm season turfgrass in Florida, S39

Podosphaera spp.

P. clandestina

Burkhard cyclone sampler for detection of, S106

on cherry, chasmothecia development and dispersal, S203

$P$. macularis, Burkhard cyclone sampler for detection of, S106

P. xanthii

fungicide sensitivity of, S118

on pumpkin, S261

Pokharel, R., S142, S143

Poland, J. A., 290

Polashock, J., S143

Polonik, W., 523

Polymixa graminis, on cereals, Peanut clump virus and, 1149

Pomegranate. See Punica granatum

Pomerantz, A., S143

Pompe-Novak, M., 1292

Pond, E., S135

Ponts, N., 929

Poojari, S., S4, S81, S143, S144, 367, 1446

Poole, G., S144

Poon, J., S67

Pooran Desouza, S., S245, S246

Pop orthologs

Ralstonia solanacearum and, S80

Tobacco mosaic virus and, 1202

Popcorn disease, on mulberry, S35

Popko, J., S25

Popko, J. T., S262

Poplawsky, A. R., S230

Porch, T., S277

Porch, T. G., S278

Porchas, M., S249

Poromarto, S., S144

Porter, L. D., S4, S144

Posadas, A., S85

Posopsis sp. See Mesquite

Pospieszny, H., S18, S70

Post, A. R., S144

Post harvest decay, fludioxonil for control of, S37

Post-transcriptional gene silencing, ultrasensitive silicon nanowire field-effect transistor and NextGeneration Sequence for study of, S104

Potassium bicarbonate, for Monilinia spp. on peach, S97

Potassium phosphite, and Phytophthora plurivola on beech, $\mathrm{S} 40$

Potato. See Solanum bulbocastanum; Solanum tuberosum

Potato leafroll virus (PLRV)

exploring interactome using co-immunoprecipitation coupled to mass spectrometry, S63

p17 protein of, virus capsid protein and, S47

on-site detection of, S6

Potato purple top phytoplasma

homeostasis of gibberellin in tomato with, S272

plant hormones as biomarkers of early infection, S273

on tomato

abscisic acid and, S275

gibberellic acid treatment and, S272, S275

Potato spindle tuber viroid (PSTVd)

in tomato, deep sequencing for identification of, S106

Potato virus $S$ (PVS), late blight severity and, $\mathrm{S} 105$

Potato virus $X$ (PVX)

NbPSL11P protein and, S36

in pepper, $S 136$

Potato virus $Y$ (PVY)

distribution in plant organs, tissues, and cells, 1278 genetic diversity of, S88, 778

genetic typing of strain Z, 1045

introduction of necrotic strains of, S57

novel recombinant genome of, S57

in pepper, distribution and diversity of in

Turkey, S24

in potato

in Chihuahua, Mexico, S154

eIF4E genes and resistance to, $\mathrm{S} 63$

predictivity of resistance to in wild relatives of

cultivated potato, 1074

resistance gene markers, S190

in tobacco

in China, genetic diversity of, 377

overcoming host resistance during singlehost passages, S194

unusual serological activity in isolates of, S57

Pothier, J. F., S144, S145

Potnis, N., S145

Potyviruses

in cigar wrapper tobacco, S260

multiplex one-step RT-PCR for improved

detection of, $\mathrm{S} 125$

in sweet potato, $\mathrm{S} 270$

Poudel, B., S145, S268

Pourrahim, R., S62

Powdery mildew, on wheat, detection with hyper-

spectral remote sensing, S26

Powell, C., S202

Powell, C. A., S205, S206, 1097

Power laws

heterogeneity of disease incidence and, 1396

in modeling disease epidemics, different atmospheric conditions and, 1465

Pozza, E. A., S200

PPV. See Plum pox virus

Prabhu, A. S., S52, S167

Prasad, R. D., S145

Prasanna Kumar, M. K., S145

Prathuangwong, S., S32, S37, S146

Pratylenchus spp. (root-lesion nematodes)

on corn, comparison of methods for extracting, $\mathrm{S} 2.1$

on fruit trees in Iran, S175

on potato, Verticillium dahliae and, S209

on tea, distribution and population density in Iran, S75

PRDA-003, for soil-borne diseases, S194

Predajna, L., 980

Preece, J., S134

Presting, G. G., S114, S161

Preuett, J. A., S146

Priaxor

for diseases of pome fruits, stone fruits, fruiting vegetables, and potatoes, S184

as new broad-spectrum fungicide for use in row crops, $\mathrm{S} 5$

Price, J. F., S146

Prior, P., 154

Prishmann, J., S242

Probenazole, for induction of systemic acquired resistance, $\mathrm{S} 233$

Proctor, R., S22

PROCULTURE model, overview of, S47

Programmed cell death (PCD) in sunflower, Plasmopara halstedii and, 970 use of by Sclerotinia sclerotiorum to hijack host defenses and manipulate host redox environment, S86

Prom, L. K., S140

Propiconazole

for Fusicladosporium carpophilum and Alternaria spp. on almond, S54

for Sclerotinia homeocarpa on turfgrasses, resistance to, $\mathrm{S} 262$

Typhula ishikariensis and, S17

Protect U.S. Program, overview of, S45

Prothioconazole, Cylandrocladium spp. on peanut, $\mathrm{S} 19$

PRSV. See Papaya ringspot virus 
Prunus necrotic ringspot virus (PNRSV) detection and characterization of in Iran, S150 in National Clonal Germplasm Repository, $\mathrm{S} 134$ in rose, $\mathrm{S} 62$

Prunus replant disease, Cylindrocarpon macrodidymum on roots of almond and peach with $\mathrm{S} 15$

Prunus spp.

apricot, Plum pox virus in, molecular epidemi-

ology of in Japan, 567

Armillaria astoyae on, S188

$P$. avium (sweet cherry)

Calosphaeria pulchella on, S179

Pseudomonas syringae pv. syringae on, management of, S27

Blumeriella japaii on, S86

cherry

Blumeriella japaii on, S86

Monilinia fructicola on, sterol demethylation inhibitor fungicides and, S2.6

multiple viruses in Colorado orchards, S143

new broad-spectrum fungicide for, $\mathrm{S} 184$

Podosphaera clandestina on, chasmothecia development and dispersal, S203

Cylindrocarpon spp. on, S160

P. dulcis (almond)

Aspergillus section Flavi on, aflatoxin producing potential and community structure of, S44

Colletotrichum acutatum on, effect of wetness duration and temperature and cultivar sensitivity on, 1013

Cylindrocarpon spp. on, S15, S160

Fusicladosporium carpophilum on: natural fungicide resistance and, S54; QoIresistant populations, $\mathrm{S} 111$

Phyllactinia guttata on, S157

phytoplasmas on, S172

Tomato ringspot virus in, $\mathrm{S} 160$

Xylella fastidiosa on, lipopolysaccharide and virulence and host specificity of, S38

Meloidogyne incognita in, $M a$ gene and resistance against, 945

Monilinia spp. on, spatial distribution and

genetic population structure, S221

P. persica (peach)

Armillaria sp. on, high planing, root collar excavation and, S161

Cylindrocarpon spp. on, S15, S160

fungi and oomycetes associated with replant problem in, S197

Monilinia fructicola on: scutellaria for control of, S107; sterol demethylation inhibitor fungicides and, S2.6

Monilinia spp. on, management with biorational fungicides, $\mathrm{S} 97$

new broad-spectrum fungicide for, $\mathrm{S} 184$

phytoplasmas on, S172

Plum pox virus in, molecular epidemiology of in Japan, 567

Pseudomonas syringae on, S174

Xanthomonas arboricola pv. pruni on, S144, S261

Plum pox virus in

analysis of epitope structure of coat protein, 611

LAMP assays for detection of, S58

molecular, ultrastructural, and biological characterization of isolates from Pennsylvania, 627

molecular epidemiology of in Japan, 567

sequence variability, recombination analysis, and specific detection of the W strain, 980

spatial dynamics of, S63

Xanthomonas arbicola pv. prunei on, S144, S261

Pruvost, O., 887
Pryor, B., S171

Pscheidt, J., S146

Pscheidt, J. W., S71, S172

Pseudoleptomastix mexicana, for control of Para-

coccus marginatus on papaya, S85

Pseudomonas spp.

$P$. aeruginosa, on oil palm, induced resistance and, S192

P. aureofaciens, for control of Sclerotinia

homeocarpa on turfgrasses, S2.9

biological control properties of, $\mathrm{S} 117$

P. cannabina pv. alisalensis

on Brassica spp., S189

on crucifers, S157

for Clavibacter michiganensis on tomato, S98

P. CMR12a, for control of Rhizoctonia solani on bean, 996

for control of Helminthosporium solani on potato, S257

P. fluorescens

A506 for control of Erwinia amylovora on pear, 113, 299

Q2-87 and Q8r1-96, novel pathways of, S231

Q8r-1 and Q2-87 strains, genome sequence of, $\mathrm{S} 117$

SP007s for control of rice pathogens, S146 on tomato, in live coating seed, S116

TonB-dependent outer membrane proteins of, S70

for Gaeumannomyces graminis var. tritici on wheat, S201, 1481

genomic diversity of biocontrol strains of, S231

LBUM300, monitoring gene expression of in soil, S130

P. marginalis, on garlic, S115

phenazine-1-carboxylic acid production by, control of Streptomyces scabies on potato and, S9

$P$. savastanoi, on olive and oleander, IS53 transposase promoter and, S29

on sorghum, effect of sorghum genotype on, S243

spontaneous GAC mutants and biological control, S45

$P$. syringae

on lilac, S172

on Lomatium spp., S159

on parsley, rapid identification of pathovars, 847

on pea, detection of in seeds, S36

pv. persicae, on peach, S174

pv. phaseolicola: on bean, S242; on snap bean, copper resistance in, S202

pv. syringae: on bean, S242; iron responsive sigma factor and achromobactin biosynthesis in, S64; on peach, S174; on sweet cherry, management of, S27

pv. tomato: on Arabidopsis thaliana, NDR1 integrin-like protein and, S2.5; plant activators and salinity-induced predisposition, S147; plasmodesmatal localized protein, malic acid transporter and, S97

rsmA in phytotoxin-producing pathovars, S93

on wheat, field evaluation for resistance, S2.4

P. tolaasii, on Agaricus bisporus, essential oils for control of, $\mathrm{S} 7$

$P$. viridiflava

on milk vetch, $\mathrm{S} 90$

on parsley, $\mathrm{S} 116$

Pseudoperonospora spp.

P. cubensis

on cucumber: sexual reproduction of, S38; in solar greenhouses, early warning method for, S197

on cucurbits, temperature and wetness parameters and, S127

genetic relatedness of to Pseudoperonospora humuli, 805

genetic structure of populations, S149

on melon, sexual reproduction of, S38

spatiotemporal spread of, 451

temporal and spatial spread of, S131

$P$. humuli, genetic relatedness of to Pseudoperonospora cubensis, 805

Pseudopityophthorus agrifola (western oak bark beetle), Geosmithia and Ophistoma spp. on oak and, S249

Pseudotsuga menziesii (Douglas fir)

Fusarium spp. on, S171

Phaeocryptopus gaeumannii on, 583

Pseudozyma aphidis, on Peronospora belbahrii on basil, S263

Pseudozyma flocculosa, Ustilago maydis as model system for study of glycolipid gene cluster in, S260

PSTVd. See Potato spindle tuber viroid

Psyllids. See also Diaphorina citri; Trioza erytreae,

Candidatus Liberibacter asiaticus in, S95

Psyllobora vigintimaculata

as bioindicator for Erysiphe necator, S139

on grape, effects of fungicide on, S250

P-TRAC (Pathogen Transport and Response-tool

for Agricultural Canopies), development of, S112

Puccinia spp.

comparative genomic analysis of, S208

$P$. emaculata, on switchgrass

effect on ethanol production potential, S174

in Mississippi, S61

in Tennessee, S16

$P$. graminis

on barley, rpg4 and rpg5 genes and resistance against, $\mathrm{S} 21$

detection of in simulated metagenome, S50

f. sp. tritici on wheat: management strategies using fungicides, S243; resistance to Ug99 race group, S127, 1418; Ugg lineage of, S132

$P$. helianthi, on sunflower

fungicides for management of, S243

hybrid susceptibility and impact on yield, S2.2

resistance to, 241

timing trial in Nebraska 2010, S2.7

$P$. hemerocallidis, on daylily, management of, S22

$P$. horiana, on chrysanthemum, S91

$P$. polysora, strategies for management of in Georgia, S9

P. psidii

in Hawaii, distribution, pathogenicity, and molecular analysis of, S180

microsatellite profile of, $\mathrm{S} 127$

multilocus genotypes indicating host selection in, S127

overview of, S215

$P$. punctiformis, for control of Canada thistle,

S39, S258

P. striiformis

expressed sequence tag-derived SSR markers for, S35

on wheat: evaluation of varieties for host resistance, S26; interaction between host and pathogen, S207

P. striiformis f. sp. tritici

integrated system for monitoring and forecasting of, S103

Pst effector highly expressed in haustoria, S198

race variation in China, $\mathrm{S} 83$

on wheat: in China and US, virulence and molecular comparison, S201; comparison of old and new strains, S121; Lankao 5 strain and resistance, S147; mapping of new genes for resistance, S205; pheno- 
typing resistance and virulence, S121; predicting potential yield loss of, 544 virulence diversity of international collections of, S164

on sugarcane, monitoring spore concentrations of, S61

P. triticina, on wheat

foliar fungicides and, S265

genetic differentiation of populations, 870

$\mathrm{N}$-deficiency and, S22

race and virulence dynamics in China, S33

on wheat, novel resistance against, S25

Puehler, A., S144

Pueraria spp. (kudzu), Phakopsora pachyrhizi on, S199

Pugalendhi, L., S227

Pugliese, M., S66

Pumpkin. See Cucurbita pepo

Punica granatum (pomegranate), Ceratocystis fim-

briata on, volatile organic compounds of, S103

Pupakdeepan, W., S146

Pupola, N., 980

Puppala, N., S168

Puri, K. D., S5, S146

Pusey, P., S26, S146, S232

Pusey, P. L., 710, 1234

Putman, A. I., S87, S147

Putnam, M., S216

Putoa, R., S219

PVY. See Potato virus $Y$

Pye, M. F., S147

Pyraclostrobin

for Asochyta rabiei on chickpea, detection of resistance, $\mathrm{S} 62$

for Botrytis cinerea on apple, resistance against, 1385

for Cercospora zeae-maydis on corn, S31

effect of on corn stalk health, S2.8

Pyrenophora spp.

$P$. teres, on barley

detection in conidia and seed, S98

ELISA for detection of, S24

Laetisaria arvalis for biological control of, S98

P. tritici-repentis, on wheat

QoI-resistant populations, S2.7

QTL contributing resistance against, S2.7

Pyrethum. See Chrysanthemum spp.

Pyricularia spp.

P. grisea

on millet, $\mathrm{S} 164$

on wheat, S264

P. oryzae, on rice, Chromolaena odorata extract for control of, 231

Pyrosequencing

for characterization of potato common scab suppressive soil, S156

of fungal endophytic community in beech forest, $\mathrm{S} 7$

for influence of organic and conventional farming systems on bacterial communities, $\mathrm{S} 102$

Pyrus pyrifolia (pear)

Erwinia amylovora on

analysis of products evaluated for control of, 512

biological control of, 113, 299

genes regulated by $\mathrm{RcsB}$ and $\mathrm{RcsC}$ in, S186

RcsC sensor kinase from, 710

streptomycin-resistant, S128

Penicillium expansum on, S182

phytoplasmas on, $\mathrm{S} 172$

Xylella fastidiosa on, S31, S41

Pythium spp.

$P$. aphanidermatum

pathogenicity gene expression during infection of different hosts, S247

Pythium nunn for control of, S177

sensitive detection and discrimination of, S9 on soybean, seed exudates and resistance to, $\mathrm{S} 11$

on carrot, $\mathrm{S} 110$

in certified organic fields for vegetable production in Washington, S4

on corn, S173

P. cryptoirregulare, on impatiens, S258

cymene for control of spore germination, S109

$P$. deliense, sensitive detection and discrimination of, S9

influence on bacterial community in recycled irrigated water, S23

on intensive crops in Argentina, S136

$P$. irregulare, on soybean, mapping partial resistance to, $\mathrm{S} 48$

mefenoxam sensitivity of, $\mathrm{S} 110$

$P$. nunn, for control of $P$. ultimum and $P$. aphanidermatum, $\mathrm{S} 177$

$P$. oligandrum, for control Esca pathogenic attack, S21

partial saturation of ornamentals for reduction of, S48

on peanut, $\mathrm{S} 265$

in recycled irrigation water, S258

on snap bean

chloride salt and changes in tap root calcium partitioning, S26

fungicide sensitivity of, S69

and other crops in eastern US, S259

on soybean

chloride salt and changes in tap root calcium partitioning, S26

effect of fungicide seed treatments on, S14 on strawberry, S108

on tobacco, transplant production in hydro-

ponic greenhouses and, S84

P. ultimum

on cotton, Reynoutria sp. for control of, S172

on cucumber, Enterobacter cloacae 501R3 for control of, 271

on potato, screening for resistance, S190

Pythium nunn for control of, S177

on rose, Martelella endophytica for control of, S15

on soybean, Reynoutria sp. for control of, S172

Qandah, I. S., S147

Q-Bank, overview of, S218

QBOL, barcoding for identification of quarantine nematodes and close relatives, $\mathrm{S} 90$

Qi, F., S107

Qi, L.-L., 241

Qi, M., S186

Qi, Y., S38

Qian, J., S197

Qian, X., S233

Qianfu, S., S147, S148

Qiang, Y., S147

Qiming, J., S147, S148

Qin, G., S176

Qin, H., S66

Qingyun, G., S68, S147

Qiu, D., S148, S200

Qiu, J., S107, S148

Qiu, W., S202, 1081

Qiyun, Y., S148

Qodir, H. A., S115

QoI fungicides. See Quinone outside inhibitor fungicides

Qu, F., 1264

Qu, X., S188

Quantitative trait loci (QTL)

and Cucumber mosaic virus genes, multigenic system controlling viral systemic infection determined by, 575

effect of rater variability and different rating scales on, 290

for Mycosphaerella graminicola on adult winter wheat plants, 1209

for rapid identification of $P$. syringae $\mathrm{pv}$. coriandricola and $P$. syringae pathovars on parsley, 847

for resistance to Magnaporthe oryzae, 176

for resistance to Meloidogyne incognita on cotton, S187

for resistance to Phytophthora sojae, S186

for resistance to Pyrenophora tritici-repentis on wheat, S2.7

for Stagonospora nodorum on wheat, 1278

transmission of Soybean mosaic virus and

SMV-induced seed coat mottling in soybean and, 750

for white pine resistance to Cronartium ribicola, 904

Xanthomonas axonopodis pv. passiflorae on bean and, 425

Quarantine. See also Biosecurity

digital diagnostic tools for, S218

managing pest risk of plants for planting in international trade, S114

pest interception systems as overwhelmed and, S20

problems in international programs, S218

programs for sugarcane, grasses, rice, and bamboo, S114

surface plasmon resonance technology for pathogen detection and, S215

Queen of fruit. See Garcinia mangostana

Quemada, H., S237

Quercus spp. (oak)

Botryosphaeria spp. on, species complex, S11

Brenneria quercina and Allokemes sp. on, S168

Ceratocystis fagacearum in, detection with rtPCR, S95

fungal species associated with mortality in southern California, S248

Geosmithia spp. on, western oak bark beetle and, S249

Ophiostoma spp. on, western oak bark beetle and, S249

Phytophthora ramorum on

bole infection in Canyon live oak, S8

dead leaf litter in aquatic systems and, S8

influence of forest type on transmission of, 492

migration within North America and Europe and, 166

spatial sampling for detection of outside of eradication zone, 725

Quesada-Ocampo, L., S149

Quesada-Ocampo, L. M., S63, 1061

Quinone outside inhibitor fungicides (QoI)

for Asochyta rabiei on chickpea, monitoring for resistance to, $\mathrm{S} 62$

for Cercospora zeae-maydis on corn, S31

for Erysiphe necator on grape, stability of resistance, $\mathrm{S} 274$

for Fusicladium effusum on pecan, resistance monitoring, S11

for Fusicladosporium carpophilum on almond, resistance to, $\mathrm{S} 111$

meta-analysis of corn yield response to, 1122

plant health and, S213

Quintanilla, M., S216

Quirin, E. A., S18

Quispe, C., S149, S2.8

Quito-Alva, D. F., S115, S149, S154

Quorum sensing

in Burkholderia glumae on rice, S264

in Erwinia amylovora, S2.2

in Pantoea agglomerans, S136

in Xanthomonas citri pv. citri, DSF-mediated regulon of, S67

R2R3MYB transcription factor, Botrytis cinerea on grape and, $\mathrm{S} 163$

Race TTKSK. See under Puccinia graminis f. sp. tritici 
Raczkowski, C. W., S53

Radar, pecan scab predictions and, S138

Radish. See Raphanus sativus

Radmer, L. E., S10

Radopholus similis, on Anthurium andraeanum,

innate response in tissue cultures, S113

Radovich, T., S167

Radwan, O., S149, S150, 970

Raffaelea spp., on avocado, S50, S78

Raghavan, S., S10

Raguchander, T., S159

Ragweed. See Ambrosia spp.

Rahjoo, V., S88

Rahman, M., S27

Rahmanian, P., S150

Raid, R. N., S61

Rainfed agroecosystems

integrated management of food legume diseases in, S226

water limited wheat-based cropping systems in West Asia and North Africa, S226

Rain-free period, haloxyfop-methyl application and, S8

Rajagopalan, P. A., 367

Rajashekara, G., S195

Rakhshandehroo, F., S3, S44, S150, S160

Rallos, L. E., S274

Ralstonia solanacearum

AWR effector proteins and virulence of, S168

bacteriophages as biocontrol agents for, S145

CANARY for rapid detection of, S106

on ginger, $\mathrm{S} 124$

microsatellite analysis for diversity assessment, S74

phiRSS1 filamentous phage and virulence of, $\mathrm{S} 2$

on potato, characteristics of Japanese strains, S173

race 3 biovar 2, rapid detection of in field, S67

species complex, 154

on tobacco, Pseudomonas spp. on and resistance induction, S72

on tomato

Bacillus cereus AR156 and resistance in, S129

grafting for control of, S136

salicylic acid, ethylene pathways and resistance, $\mathrm{S} 121$

SSR linkers linked to QTL associated with resistance, $\mathrm{S} 186$

type 3 effector PopS and, S80

Ramadugu, C., S69, S113, S150, S151

Ramakrishnan, S., S227

Raman, V., S150

Ramaraj, T., S208

Ramasamy, G., S162

Ramasamy, S., S150

Ramillete, E. G., S122

Ramirez, P., S151

Ramming, D. W., 502

Ramos, B., 470

Ramsey-Kroll, A., S32

Ramulispora sorghi, on sorghum, disease sever-

ity, microsclerotium properties and, S18

Randall, J., S55

Randles, J. W., S85

Rane, K. K., S22, S117

Ransom, J., S244

Rao, V. P., S164

Raphanus sativus (radish), Streptomyces scabiei in, tryptophan and regulation of thaxtomin A and IAA production in, 1045

Rappaport, K., S106

Rapusas, H. R., S227

Rascoe, J., S95

Raspberry. See Rubus spp.

Raspberry bushy dwarf virus (RBDV), Raspberry

leaf mottle virus and, S149, S229

Raspberry latent virus (RpLV), transmission by aphids, S149
Raspberry leaf mottle virus (RLMV)

overview of, S229

Raspberry bushy dwarf virus and, S149

Ratcliffe, S. T., S45

Rathe, A. A., S151

Ratoon, Burkholderia glumae in, S205

Rauf, A., S226

Rauscher, G., S46

Ravanlou, A., S12

Ravel, J., S231

Ravi, K. S., 367

Ravichandran, A., S33

Ravindran, A., 1285

Ravnikar, M., S45, 1292

Ray blight. See Phoma ligulicola var. inoxydabilis

Razi, M. F., S150, S151

$R B$ gene, resistance against Phytophthora infes-

tans on potato and, 263

RBSDV, see Rice black-streaked dwarf virus

RCNMV. See Red clover necrotic mosaic virus

RcsBCD phosphorelay system, Erwinia amylovora and, $\mathrm{S} 186$

RcsC sensor kinase, from Erwinia amylovora, 710

Reactive oxygen species

Magnaporthe oryzae on rice and, MoHYR1 and, S76, S273

Pantoea stewartii subsp. stewartii on corn and, $\mathrm{S} 23$

Read, A., S124

Reardon, C. L., S146, 1234

Rearick, E., S172

Rebollar-Alviter, A., S151

Rebouças, T. H., S128

Recendez-Alvarado, M., S54

Rech, N. D., S268

Red clover necrotic mosaic virus (RCNMV), copackaging of genomic RNAs and virion accumulation of, S137

Red palm weevil. See Rhynchophorus ferrugineus

Red ring nematode. See Bursaphelenchus cocophilus

Reddy, M., S270

Reddy, M. S., S204

Redinbaugh, M., S37

Redinbaugh, M. G., S151

Reed, D., S84

Reed, D. L., S74

Reese, B. N., 797

Regnault-Roger, C., S21

Rego, M. J., S166

Regulation of exotic pathogens, S213

Rehmania glutinosa, Ribgrass mosaic tobamovirus in, S91

Reid, J., S65

Reid, L. M., S251, S252

Reilly, C., S193

Reininger, V., S151

Reinsel, M. D., S181

Reis, A., S152

Reis, A. B., S43

Reisinger, P., S93, S237

Reitz, S. R., S189

Remenant, B., S80

Rémus-Borel, W., S183, S257

Ren, R., S205

Ren4 locus, and resistance to Erysiphe necator on grape, 502

Reniform nematode. See Rotylenchulus reniformis

Replant diseases, Cylindrocarpon spp. on almond and peach and, S160

Resende, R. S., S152

Resistance. See also Host resistance

to ALS (acetohydroxyacid/acetolactate synthase) inhibiting herbicides, S236

of Alternaria alternata on citrus, against fungicides, S182

of Botrytis cinerea to boscalid, 986,1385

to fenhexamid, S158

to fungicides, $\mathrm{S} 90$ to multiple fungicides, S56, 1176

to pyraclostrobin, 1385

against CAA herbicides, cesA3 mutations in

Phytophthora capsici and, S34

of Cercospora sojina

to azoxystrobin, $\mathrm{S} 132$

to fungicides, S267, S2.9

of cucurbit powdery mildew populations to fungicides, S99

of Erisyphe necator, to QoI fungicides, S274

of Erwinia amylovora

to kasugamycin, 192

to streptomycin, S128, 182

to fungicides, mutation range leading to, S166

of Fusarium fujikuroi on, to prochloraz, S91

of Fusicladosporium carpophilum and Alter-

naria spp. on almond, to fungicides, S54

gene flow and, S236

to herbicides as threat to dryland farming in

Mediterranean, S236

laboratory methods for detecting and characterizing, S228

microplate assay for Xanthomonas spp. resistance to copper, S75

non-host plant defense against multiple pathogenic fungi and, S68

against pesticides as global issue, S235

of Phytophthora capsici

to fluopicolide, S110

to fungicides, S79

to zoxamide, 1104

of Podosphaera xanthii on pumpkin, to fungicides, S261

of Pseudomonas syringae pv. phaseolicola, to copper, S202

of Pyrenophora tritici-repentis, against QoI fungicides, S2.7

of Pythium spp., against mefenoxam, S110

safety of transgenic disease-resistant crops, S237

of Sclerotinia homeocarpa, to propiconazole, S262

of Venturia inaequalis

to fungicides, S114, S128, S242, S274, S2.3

integrated pest management and, S213

Restrepo, S., S62, S120, S152, S179

Restrepo Benavides, M., S152

Restrepo Restrepo, S., S152

Reticulitermes spp., electronic-nose for detection and discrimination of, $\mathrm{S} 192$

Rey, C., S49

Rey, M. E. C., 1159

Rey, P., S21

Reyes Caldas, P. A., S152

Reyna, R., S152

Reynolds, A.M., 1465

Reynolds, G., S152

Reynolds, G. J., S153

Reynoutria sp., for control of Rhizoctonia solani and Pythium ultimum on soybean and cotton, S172

Rezaee, M. B., S7

Rezaee, S., S13, S75, S142

Rezzonico, F., S232

Rhizobacteria spp.

and Colletotrichum acuatum on pepper, 666

and Magnaporthe oryzae on rice, S5

plant growth promoting

Bacillus vallismortis and, S234

IPM for tropical vegetables in South India and, S159

Rhizoctonia spp.

on barley, S161

cymene for control of spore germination, S109

distribution in European soils, S160

hypovirulent isolates of, assessment of resistance pathways induced in Arabidopsis thaliana by, 828

induction of resistance in Arabidopsis by, $\mathrm{S} 168$ new selective medium for isolation of, $\mathrm{S} 170$ 
resistance of Brachiaria spp. to, S6

on rhododendrons and azaleas, leaf wetness and, S39

on rice, response of to plant extracts, S11

on seashore paspalum, $\mathrm{S} 87$

R. solani

on apple, Brassica juncea seed meal-induced suppression of, S249

on bean, S159, 996

on corn, sedaxane for control of, S132

on cotton, Reynoutria sp. for control of S172

on creeping bentgrass, fungicides for control of, S41

on faba bean, fungicide seed treatments for, S30

inhibition of by endospore-forming bacteria from landscape planting beds, S130

on potato: comparison of methods for identification of, S191; for disease management, S30; postharvest dark skin spots as oversuberization response to, 436

resistance of transgenic plants expressing lactoferrin protein to, $\mathrm{S} 97$

on rice: chitinase gene and disease resistance, S100; Chromolaena odorata extract for control of, 231; ethylene overexpression for resistance against, S71 genetic basis of resistance, S170; inhibition by Sarocladium oryzae, S166; $B$ subtilis for control of, S204; suppression with brassica biofumigation crops, S204 testing mega-varieties for susceptibility, S112

on snap bean, chloride salt and changes in tap root calcium partitioning, S26

on soybean: chloride salt and changes in tap root calcium partitioning, S26; Heterodera glycines and, S2.3; negative interactions between glyphosate and azoxystrobin and, S126; post-emergence herbicides, strobulurin fungicides and, S203; Reynoutria sp. for control of, S172; sedaxane for control of, S132; soybean cyst nematode and, S157

on sugar beet: aggressiveness and crop rotation, S19; azoxystrobin for control of, S89, S245; depth at which causes infection, S246; genetic characterization of population isolated from, S159; metconazole seed treatment for, S118; re mote sensing for detection of, S153 storability and, S172

on sugarcane, NMR for belowground imaging of, S72

on strawberry, S108

on wheat, S161

Rhizomania. See Beet necrotic yellow vein virus

Rhizopus stolonifer, on strawberry, glucoraphane and, S128

Rho, J., S36

Rhododendron spp.

Erisyphe azaleae on, S251

Phytophthora kernoviae on, S191

Phytophthora ramorum on, S177, 1457

Rhizoctonia spp. on, leaf wetness and, S39

Rhodopseudomonas palustris, isolated from contaminated sludge, biodegradation of cypermethrin by, S106

Rhopalosiphum padi (aphids), on wheat, arbus-

cular mycorrhizae and, S2

Rhynchophorus spp., on palms, S3, S254

Ribeiro, P. S., S109

Ribes spp.

elimination of viruses in by in vitro therapy, S81

Gooseberry vein banding associated virus in, S194

novel vitivirus isolated from, $\mathrm{S} 154$

Ribgrass mosaic tobamovirus, in Rehmania gluti- nosa, S91

Ribosomal intergenic spacer analysis, for soil fungal community structure in different peanut rotation sequences, 52

Rice. See Oryza sativa; Zizania palustris

Rice black-streaked dwarf virus (RBSDV), on corn in China, S82

Rice blast. See Magnaporthe oryzae

Rice stripe virus (RSV), new methodology for identification of, S205

Richard, J. L., S222

Richard, P., S71

Richard-Forget, F., 929

Richardson, F., S191

Richardson, P., S74

Richman, R., S159

Richter, B. S., 223, 666

Richwine, N., 627

Ridao, A. D., S64

Ridenour, J. B., S153

Rideout, S., S52, S259

Rideout, S. L., S69, S136

Ridgway, H. J., S178

RIFdb, for classification of plant-associated

bacteria using RIF marker, S161

Riggs, J. L., S124

Riley, K., S31, S48, S247

Riley, R. T., S135, S206, S222

Rintoul, T. L., S247

Rioux, D., S262

Rioux, R., S153

Riptortus pedestris (bean bug) on soybean, pheromone trap catches, timing of invasion and, S48

Riquelme, D., S71

Risk analysis

food safety and, S217

need for weed risk assessment and, S237

Risser, P., 1209

Ristaino, J. B., S153

Ritson, R. M., S153

Ritzenthaller, C., S63

Rivara, K. L., S26

Rivard, C. L., S79

Rivera, L. I., S154, S278

Rivera, M., S57

Rivera, V., S278

Rivera Vargas, L. I., S253, S276

Rivera-Bustamante, R., S54

Rivera-Vargas, L. I., S163, S253, S254, S255, S277

Rizzo, D. M., S8, S178, 492

RNAi-mediated silencing geminiviruses and, S207

of parasitism genes of Meloidogyne incognita, S61

soybean resistance to mixed viral infections and, 1264

RNA-seq, for analysis of interaction between

Sclerotinia sclerotiorum and pea, S2.9

Robbins, M. D., 1217

Roberge, B., S262

Robert, M., S206

Roberts, A., S66

Roberts, D., S93

Roberts, D. P., 271

Roberts, P. A., S187

Robertson, A., S50, S153, S190, S223, S242

Robertson, A. E., S15, S31, S246, 1122, S2.1

Robertson, C. L., S268, S269

Robertson, N., S154

Robertson, N. L., S154

Robideau, G. P., S247

Robinson, J., S38

Robinson, T. L., S27

Robles-González, M., S133

Robles-Hernandez, L., S154

Rocha, C. S., S104

Rocket (Eruca vesicaria), Fusarium oxysporum on, S65
Rodrigues, F. A., 92, S152, S264

Rodrigues, I., S222

Rodrigues, J. C., S276

Rodrigues, R. A., S123, S155

Rodríguez, A., S278

Rodriguez, C. G., S59

Rodriguez, D. A., S179

Rodriguez, G., S23

Rodriguez, J., S254

Rodriguez, L., S155

Rodríguez-López, M. J., 1191

Rogers, E., S155

Rogers, E. E., S99

Rogers, M., S138

Rogers, S., S155

Roh, J., S155, S165, S264

Rojas, S., S99

Rojas-Martínez, R. I., S123

Roldán-Nestor, O., S151

Rollemberg, C. L., S155

Rollins, J., S39

Rollins, J. A., S104

Rolshausen, P., S14, S56

Rolshausen, P. E., S156

Romag, A., S150

Román Avilés, B., S276

Romanazzi, G., S156

Romero, G., S278

Romero, H. M., S254

Romero, M., S14

Ronald, P., S141

Roose, M., S150, S151

Root rot. See Phoma sclerotioides

Root-knot nematodes. See Meloidogyne spp.

Root-lesion nematodes. See Pratylenchoides spp

Rootworms. See Diabrotica spp.

Roper, C., S2

Roper, M., S23

Roper, M. C., S38

Rosa spp.

Arabis mosaic virus in, S44

Prunus necrotic ringspot virus and Apple mosaic virus in, $\mathrm{S} 62$

Rosellinia necatrix, Fusarium oxysporum and Ophyostoma stenoceras on, S59

Tomato ringspot virus in, S160

Rosada, L. J., 923

Rosellinia necatrix, on rose, S59

Rosenberger, D. A., S213, S262

Rosenzweig, N., S156

Roskamp, G. K., S134

Rosmarinus officinalis (rosemary) extract, for

Rhizoctonia spp. and Sclerotium hydrophilum on rice, $\mathrm{S} 11$

Ross, D., S74

Ross, R. E., S126

Ross-Davis, A. L., S127

Rossi, V., S24

Rosskopf, E., S156

Rosskopf, E. N., S32

Rosyara, U. R., S242

Rotenberg, D., S12

Rothrock, C., S111, S170

Rothrock, C. S., S209

Rotylenchulus reniformis on cotton

Bacillus firmus strain GB-126 for control of, S29

host resistance, $\mathrm{S} 265$

management of in multiple soil types with Telone II, S266

soil moisture content and, S123

on soybean, potential resistance to, $\mathrm{S} 99$

sunn hemp cover crop for suppression of, S113

Roundup Ready cropping systems

plant disease and plant health and yield and, S93

Rhizoctonia solani on sugar beet and, negative interactions with azoxystrobin, S126 
Rouse, D., S70

Rouse, M. N., 1418

Roux, J., S215

Rouxel, T., S230

Rowhani, A., S4, S61, S62, S134, S134, 1446

Roy, A., S36, S156

Roychowdhury, M., S156

Royer, T. A., S157

Rozwalka, L. C., S17

Rpi-blb1 gene, in potato, Phytophthora infestans resistance and, S69

$R p L V$. See Raspberry latent virus

RsmA, phototoxin-producing Pseudomonas syringae pathovars and, S93

RSV. See Rice stripe virus

Ruan, H., S45

Rubber, Microcyclus ulei on, S75

Rubin, A., S38

Rubin, B., S236, S239

Rubio, I., S157

Rubus spp.

blackberry

Botrytis spp. on: identification of new, S103; postharvest control of, S151

elimination of viruses in by in vitro therapy, $\mathrm{S} 81$

Erwinia amylovora on, EopI gene as host specificity factor, 935

new ampelovirus infecting, $\mathrm{S} 158$

new emaravirus infecting, S70

raspberry

Botrytis cinerea on, $\mathrm{S} 69$

elimination of viruses in by in vitro therapy, S81

Erwinia amylovora on, EopI gene as host specificity factor, 935

functional biodiversity of, S71

Phytophthora rubi on, S248

Rucker, K., S19

Rudolph, K., S157

Rudolph, K. W. E., 1355

Rueda, A., S234

Ruhl, G., S244

Ruhl, G. E., S73

Rumore, A., S230

Rundquist, D., S71

Runge, F., S149

Rupe, J., S38

Rupe, J. C., S11, S103

Rush, C. M., S194

Rush, M. C., S166, S266, S268

Rush, T. A., S157

Rushanaedy, I., S216

Russell, P. F., S157

Russell, S., S193

Russo, J., S46

Rustroemia floccosum. See Sclerotinia homeocarpa

Rwahnih, M. Al, 1446

Rwegasira, G. M., 1159

Ryegrass, perennial. See Lolium perenne

Saad, A. T., S157

Saalau Rojas, E., S158

Sabanadzovic, S., S70, S158, S181

Sabbatini, P., S11

Sable, S. V., S30

SABP-2 protein, and systemic acquired resistance,

effect of pesticide treatments on, $\mathrm{S} 94$

SABYV. See Suakwa aphid-borne yellows virus

Saccharum spp. (sugarcane)

Acidovorax avenae on, $\mathrm{S} 64$

Agrobacterium-mediated transformation of, S122

Heterodera schachtii and Rhizoctonia solani on, NMR for belowground imaging of, S72

Leifsonia xyli subsp. xyli on, S180

Puccinia spp. on, monitoring spore concentrations of, S61

quantification of spray drift from aerial application on, S8

USDA-APHIS quarantine program for, S114

in vitro multiplication method for transgenic lines of, $\mathrm{S} 122$

Xanthomonas sacchari on, EngA cellulase gene in asymptomatic, S96

Saeki, T., S56

Saenz, P., 611

Sagebrush, big. See Artemisia tridentata

Saini, M., S1

Sainju, U. M., S98

St. Lawrence Seaway, pests, pathogens, and produce on, $\mathrm{S} 213$

Saito, H., S13

Saito, S., S158

Sakai, H., S13, 410

Sakthikumar, S., S208

Sakumoto, S., S159

Salamon, P., S136

Salánki, K., S126

Salas, B., S95, 687

Salaudeen, M., S158

Salcedo, S., S254

Saldarelli, P., S43

Saleh, A. A., S19

Salicylic acid

and host resistance against Ralstonia solanacearum on tomato, $\mathrm{S} 121$

systemic acquired resistance and, S91

Salinari, F., S24

Sall, D. S., S228

Salman, A., S143

Salmonella spp.

detection of in fresh produce, $\mathrm{S} 43$

E. coli $0157: \mathrm{H} 7$ and, multiplex PCR for, S77

S. enterica

comparative genomics of plant and animal isolates, $\mathrm{S} 19$

on lettuce: antagonistic yeasts for control of, S66; Pectobacterium carotovorum and, S96

mechanism of persistence of, S212

in produce production environment, S212

on tomato: effect of phase variation on, S200; high-throughput screening for, S176; pectolytic activity of phytopathogens and, S212

Salvia sp., Clerodendrum golden mosaic China virus in, $\mathrm{S} 181$

Samac, D. A., S29

Samiyappan, R., S58, S159, S227

Sampangi, R., S159

Sampling, for detecting fungicide resistance, S228

Sanada-Morimura, S., S159

Sances, F., S156

Sánchez-Aguirre, M. D., S3

Sanderlin, R. S., S267

Sanders, F. H., S9, S56, S97, S159, S266, S269

Sandra, B., S59

Sang, M. K., 666, 732

Sanogo, S., S159, S168, S250

Sant' Anna, J. R., 923

Santamaría, O., 334

Santhanam, P., S208

Santori, A., 679

Santos, H. T., S174

Santra, D. K., S159

São José, A. R., S3

Saponari, M., S43

Sappington, T., S55

SAR. See Systemic acquired resistance

Sarocladium oryzae, on rice, S166

Sarria, G., S254

Sarria, G. A., S254

Sasaki, R., S49

Sato, E., S56

Sato, S., 1264

Sato, T., S88

Satoh, K., S182

Satpute, A., S95
Sattary, M., S160

Sattler, S. E., S243

Satyanarayana, T., S2.2

Sauve, R. J., S112, S121

Savary, S., S112, S170, S223, 696

Saville, B., S247

Savory, E. A., S2.5

SBWMV. See Soilborne wheat mosaic virus

Scala, F., S160

Scale-dependent landscape epidemiology, S167

Schaad, N., S44

Schaad, N. W., S78

Schade-Schütze, A., S160

Schaefer, J., S243

Schardl, C. L., S53, S54

Schatz, B., S243, S245, S2.2, S2.7

Schaub, T., S104

Schell, M., S67

Scherm, H., 31, S37, S79, S176, S213, S221

Schilder, A. C., S160

Schilder, A. M. C., S11, S120

Schiller, C. T., S190

Schisler, D. A., S160, S200

Schlub, K., S216

Schlub, R. L., S216

Schmale, D. G., S114, S274

Schmidt, C., S87

Schmidt, F. J., S65

Schmidt, L. S., S15, S160

Schmidt, M., S87

Schmitt, M., S129

Schnabel, G., S34, S76, S103, S161

Schneider, K., S16, S48, S81

Schneider, K. L., S114, S161

Schneider, R. W., S30, S157, S264, S268, S269

Schneider, W. L., S41, S50, S171, S176, 627

Schoelz, J. E., S7, S65

Schoen, C. D., S18

Scholl, E. H., S42

Schrimsher, D. W., S161

Schroeder, B., S161

Schroeder, B. K., S71, S77

Schroeder, K. L., S161

Schuenzel, E. L., S10

Schulte-Geldermann, E., S232

Schumann, A. W., S129

Schuster, S. C., S88

Schutte, G. C., S54

Schwartz, H. F., S12, S17, S161

Schwarz, P. B., 687

Schwind, N., 1471

Sciumbato, G., S103

Scleromitrula shiraiana, on mulberry, S35

Sclerotinia spp.

comparative analysis of small RNAs in, S148

comparative transcriptome analysis of, S148

S. homeocarpa

early-season fungicide application and, S79 on turfgrasses: characterization and distribution of mating type genes of, S147; demethylation inhibitor fungicides, plant growth regulators and, S25; DMI exposure and resistance, S267; early-season fungicide application and, S192; effects of light-weight rolling on, S2.3; effects of temperature on, S192, S2.9; influence of fungicide timing and post-application irrigation on, S87; initial inoculum and, S153; microsatellite markers for, S147; ningnanmycin for control of, S111; propiconazole-resistant, S262; Pseudomonas aureofaciens for control of, S2.9; use of temperature and relative humidity variables to predict fungicide application for, S268

S. minor

on lettuce, S249, 340, 358

on peanut: effect of postinoculation relative humidity on, S20; ICRISAT minicore peanut germplasm characterization 
and, S30; management in Texas, S193; oxalate oxidase gene and resistance, 786; population structure and genetic diversity, S59

multiplex PCR for, S2

S. sclerotiorum

aggressiveness of on multiple crops, S5

on alfalfa, sclerotial survival and natural biological control, S144

ascospore germination and infection efficiency, S245

on bean, Trichoderma spp. for control of, S109

on canola: association mapping of resistance against in world collection, S67; genetic diversity and population differentiation, S10; temporal ascospore dispersal pattern during flowering, S147

for control of Cephalanoplos setosum, S68 dispersal in birdseed, S2.7

diversity of mating type locus, apothecia formation and, S35

forecast model for carpogenic germination of sclerotia, S60

fungicide sensitivity of, S2.1

$\mathrm{G}$-protein coupled receptors in soybean and, S25

on lettuce, S249, 340, 358

mycoviruses infecting, $\mathrm{S} 83$

oxalate-minus mutants of, pathogenicity and, S104

oxalic acid, pathogenicity and, S86, S104

on pea, RNA-seq based research on interaction, S2.9

on peanut, screening core collection for resistance, $\mathrm{S} 168$

resistance against in annual bedding plants, S63

on soybean: Coniothyrium minitans for control of, S126, S245; mycoparasites of, S2.4; sclerotial viability and, S83

on turfgrasses, genetic diversity and heterothallism in, S104

Sclerotium spp.

S. cepivorum

on garlic, S179

on onion, $\mathrm{S} 52$

$S$. hydrophilum, on rice, response of to plant extracts, $\mathrm{S} 11$

S. rolfsii

genetic diversity of in southeast US, S270 on peanut, S84, S264

SCMV. See Sugarcane mosaic virus

$\mathrm{SCN}$ (soybean cyst nematode). See Heterodera glycines

Scolytus quadrispinosus (hickory bark beetle),

Ceratocystis smalleyi on hickory and, S86

Scott, B., S181

Scott, J. B., S139, S162

Scott, J. W., 1217

Scott, T., S111, S162, S248, S249

Scutellaria spp.

for control of Monilinia fructicola on peach, S107

Verticillium dahliae on, S247

SDHI fungicides, mutation range leading to resistance against, S166

SDS (sudden death syndrome). See Fusarium virguliforme

Seaweed

extract of for control of thrips on peppers, cucumbers, and Hass avocadoes, S126

for management of root diseases of watermelon and eggplant, S47

for suppression of root diseases of cotton and chili, S8

Sebacina vermifera, switchgrass drought tolerance and, S60

SecA, of Candidatus Liberibacter asiaticus, small molecule inhibitors of, S4
Sechler, A., S44

Sedaxane

as part of comprehensive seed care product for broad spectrum disease protection of small grains, S165

for Rhizoctonia solani on corn and soybean, $\mathrm{S} 132$

for seed treatment use, S133

Sedlakova, B., S99

See, D. R., S165

Seebold, K. W., S73, S84

Seed meals

for control of Macrophomina phaseolina on strawberry, S117, S249

for control of Rhizoctonia solani on apple, S249

for disease control in apple orchards, S117

Seed trade, real and imagined problems in movement of plant pathogens in, S217

Seedborne diseases, silver nanoparticles for control of, S36

Seeds, storage duration, seed quality and, S38

Seem, R., S14

Seem, R. C., 839

Seetharaman, S., S162

Seeve, C., S3

Seidl, A., S246

Seidl, A. C., S162

Seiler, G. J., 241

Seiridium cardinale, on cypress, California as

likely source of epidemic in Mediterranean region, 1408

Sekine, K., S230

Selote, D., S230

Seng, A., S149, S2.8

Sengoda, V. G., S162

Seo, S., S99, S137

Seo, Y., S137

Sep.lveda, X., S162

Seraji, A., S75

Sere, Y., S6

Serfontein, S., S54

Serpi, M., S163

Serrano-Acevedo, J., S163, S250

Serratia entomophila, for control of New Zealand grass grub, S224

Serrato-Diaz, L. M., S163, S277

Serven, B., S2.8

Sessa, G., S136, 349

Sétamou, M., S95

Sether, D., S42, S119

Sether, D. M., S229

Setose Cephalanopolos weed. See Cephalanoplos setosum

Seybold, S., S201

Seymour, L., S221

Sha, X., S266

Shabbir, A., S238

Shaffer, B. T., S172

Shah, D., S170

Shah, K. H., S163

Shaki, N., S163

Shamoun, S. F., S248

Shams-Bakhsh, M., S3, S44

Shan, W., S230

Shane, W. W., 182

Shaner, D., S236

Shaner, G., 1122

Shang, J., S103, S203

Shang, Q., S107, S163, S189, S204

Shankar, M., 1278

Shao, J., S70, S77, S214

Shao, J. Y., S96

Shao, X., S195

Shaodong, H., S84

Shapiro, M., S225

Sharka disease. See Plum pox virus

Sharma, A. M., 445

Sharma, H. C., S226

Sharma, K., 1424
Sharma, M., S164

Sharma, P., S164

Sharma, P. K., S164

Sharma, R., S164

Sharma-Poudyal, D., S164, 544

Sharon, M., S168, 436, 828

Shatters, R. G., S6

Shaw, J., S123

Shaw, R., S179

Shea, K., S258

Sheath blight. See Rhizoctonia solani

Shelby, R. J., S2.8

Shell, D. P., S165

Shelver, W. L., S24

Shem, O., S172

Shen, G., S186

Shen, Q., S204

Shen, Y., S199

Sheng, H., S165

Shepard, M., S225, S227

Shepard, M. B., S226

Shepherd, C. P., S141, S142

Shepherd, L., S16

Sherman, D. J., 627

Shetty, K., S165

Shetty, K. K., S161

Shew, B., S109, S110

Shew, B. B., 786

Shew, D., S98

Shi, J., S202

Shi, Q., S51

Shi, W., 223

Shi, X., S165

Shibu, M., S108

Shier, W. T., S1

Shim, C., S74

Shim, H., S74, S92, S100

Shimomura, N., S136

Shin, D., S36, S165, S264

Shin, S., S137

Shintaku, M., S3, S21, S124

Shintami, S114

Shiraishi, A., S146, S165

Shiraishi, T., S165

Shirinfekr, A., S75

Shishkoff, N., S166, 1457

Shock, C., S159

Shrestha, B., S266

Shrestha, B. K., S166, S268

Shuai, B., S166

Shuker, S., S131

Shuling, S., S84

Sieber, T. N., S151

Sierotzki, H., S166, S229, S2.7

Sierra, L. J., S255

Sikora, R., S72, S226

Sikora, R. A., 105

In silico simulation of massively parallel sequencing, as diagnostic tool, S41

Silicon

deficiency in uptake of, rice-Bipolaris oryzae interaction and, 92

Phakopsora pachyrhizi on soybean and, S257 plant disease resistance and, S182

response of Meloidogyne incognita to, S267 sorghum anthracnose and, S152

Silva, A. C., S8

Silva, D. D., S152

Silva, F. N., S104

Silva, G. B., S52, S166

Silva, J. A., S110

Silva, J. F., S166

Silva, L. P., S167

Silva, R. N., S109

Silva, S. J., S166

Silva-Lobo, V. L., S52, S167

Silva-Rojas, H. V., S151

Silver compounds, for control of seed-borne and foliar diseases, S69

Silvery threadmoss (Bryum argenteum), in golf 
course greens and nurseries, biological control of, $\mathrm{S} 144$

Sim, S. T., S61, S62

Sim, S.-C., 1217

Simmonds, D., S25

Simmons, R., S194

Simon, S. A., S150

Simple sequence repeat (SSR) loci, EST markers

for Puccinia striiformis and, S35

Sims, A., S153

Singh, A. K., S86

Singh, D., S127

Singh, K., S202, 1081

Singh, R., S181

Singh, S., S112

Singh, S. P., 425

Sinn, J. P., S274

Sinohin, V. O., S122

Sintim, H. O., S53

Sipes, B., S87, S113

Sipes, B. S., S113, S167, S187

siRNA deep sequencing, for detection of unknown viruses in plants, S215

Sirococcus clavigigenti-juglandacearum. See Ophiognomonia clavigignenti-juglandacearum

Sisterson, M. S., S171, S185

Sit, T. L., S137

Skantar, A., S129

Skantar, A. M., 480

Skaria, M., S95, S175

Skelsey, P., S167

Skinkis, P., S112

Skoda, S. R., S216

Skullcap. See Scutellaria lateriflora

Slinski, S. L., S167

Slippers, B., S215

Sludge, Rhodopseudomonas palustris from, bio-

degradation of cypermethrin by, S106

Small, I, S18, S261, S263

Smart, C. D., 349

Smilanick, J., 502

Smiley, R., S144

Smiley, R. W., S196

Smith, B. J., S167

Smith, C. A., S262

Smith, D., S2.9

Smith, D. L., S138, S192, S267, S268

Smith, D. R., 334

Smith, H. R., S5

Smith, J., S103

Smith, J. E., S167

Smith, L., S33

Smith, M. E., S178

Smith, P., S189

Smith, R. J., S139

Smith, S. E., S38

Smith, S. G., S141, S142

Smith, T. J., S26

Smither, M. R., S114

Smits, T. H., S19, S45, S144, S146, S232

Smits, T. H. M., 1234

SMV. See Soybean mosaic virus

Smythe, B., S168

Snap bean. See Phaseolus vulgaris

Sneh, B., S168, 828

Sneizko, R., S216

Sneller, C., S100

Snelling, J., S100, S168, S201

Sniezko, R. A., 904

Snook, M. E., S12, S135

Snover-Clift, K. L., S73

Snow molds. See Typhula ishikariensis

Soby, S., S168

Soby, S. D., S29

Social media

for exotic pest identification and extension education, $\mathrm{S} 219$

in turfgrass disease management education, S211

Sodium hypochlorite, for control of Gibberella fujikuroi on rice, $\mathrm{S} 165$

Soft rot. See Pectobacterium carotovorum

Sohn, K., S168

Soilborne wheat mosaic virus (SBWMV), in wheat, 1322

Solanum spp.

S. betaceum (tamarillo)

Colletotrichum acutatum on, S51

Phytophthora infestans on, S120

black nightshade, Alternaria tomatophila on, S74

S. bulbocastanum (wild potato)

Phytophthora infestans on: resistance to, 263; Rpi-blb1 gene of and resistance, S69 resistance to soft rot in, 205

S. carolinense (horsenettle), inbreeding depression and invasion success of, S119

S. lycopersicum (tomato)

Alternaria solani on, sensitivity to mancozeb, chlorothalonia, azoxystrobin fungicides and, S2

Bacillus cereus AR156 and resistance in, S129

Begomovirus spp. in, whiteflies and, S210

Botrytis cinerea on, molecular and biochemical characterization of resistance, S167

Candidatus Liberibacter psyllaurus on, S113

Candidatus Liberibacter solanacearum on, translocation of, 1278

chitosan and fungicides for management of early blight and septoria leaf spot in, S51

Clavibacter michiganensis on: biological control of, S98; bioluminescent, colonization under different humidity regimes, S194; detection of, S133; multivariate matrix for tracing in greenhouse operations, S101; new selective medium for isolation of, 1355; purified fire ant venom alkaloids for control of, S101; silencing of host basal defense responserelated gene expression and, 349

Eremothecium coryli on, brown marmorated stink bug feeding and, S22

Fusarium oxysporum f. sp. radicis-lycopersici on, rhizobacterial induction of systemic resistance and, S65

Geotrichum candidum on, post-harvest disease management, S52

Groundnut ringspot virus on, S189

integrated pest management for in West Africa, S60

Leveillula taurica on, impact of irrigation system on, S97

Meloidogyne javanica on, MCW-2 for management of, S190

as model system for study of huanglongbing, S113

monitoring behavior of cells by GFP labeling during infection process, S55

multiplex PCR for mixed pathogen populations of, S121

nematodes on, effect of cover crops on, S120

new broad-spectrum fungicide for, S184, $\mathrm{S} 259$

Oidium neolycopersici on, S254, S277

Peanut bud necrosis virus in, S58, S210

Pepino mosaic virus in: generation of infectious clones, S46; genetic and biological isolate variability, S70

phyllosphere fungal community characterization, S4

Phytophthora capsici on, plant activators and salinity-induced predisposition, S147

Phytophthora infestans on: in 2010 following 2009 epidemic, S41; characterization of isolates (2010), S261; coinfection of by two viruses, S25; control using high tunnels, S79; fungicide resistance, pathogenicity, and virulence, S246

phytoplasmas on, S272

potato purple top phytoplasma on: abscisic acid and, S275; gibberellic acid treatment and, S275

Pseudomonas fluorescens on, in live coating seed, S116

Pseudomonas syringae pv. tomato on: plant activators and salinity-induced predisposition, S147; plasmodesmatal localized protein, malic acid transporter and, S97

Ralstonia solanacearum on: grafting for control of, S136; resistance to, 154; salicylic acid, ethylene pathways and resistance, S121; SSR linkers linked to QTL associated with resistance, S186

resistance traits from and feeding behavior of whiteflies, Tomato yellow leaf curl virus spread and, 1191

root-knot nematode on, Paecilomyces lilacinus strain 251 for control of, S90

Salmonella enterica on: effect of phase variation on, S200; high-throughput screening for, S176; pectolytic activity of phytopathogens and, S212

Stemphylium solani on, S152

thrips on, influence of control programs on

Tomato spotted wilt virus incidence, S250

Tomato chlorotic spot virus on, S189

Tomato leaf curl peru virus in, S119

Tomato yellow leaf curl virus on, S109

transgenic, broad spectrum resistance against species of different tospovirus serogroups, S140

Verticillium dahliae on, grafting for management of, S79

viroids in, deep sequencing for identification of, S106

water uptake by, immersion depth, dwell time, fruit-water temperature and, S13

wild Solanum spp. as source of disease resistance genes for improvement of, S18 Xanthomonas spp. on, S237, S269, 1217

S. melongena (eggplant)

asafoetida and seaweed for management of root diseases of, S47

Ralstonia solanacearum species complex on, resistance to, 154

Tomato mosaic virus in, in Iran, S3

wild Solanum spp. as source of disease resistance genes for improvement of, S18

S. pimpinellifolium (wild tomato), resistance traits from and feeding behavior of whiteflies, Tomato yellow leaf curl virus spread and, 1191

S. tuberosum (potato)

Alternaria spp. on, S60, S180, S190

biological control agents for, inducible defense genes, metabolic genes and, S30

Candidatus Liberibacter solanacearum on: effect of temperature on reproduction and titer level, S194; effects of temperature on, S162; endophytic bacteria in tubers and, S108; genome sequence analysis and functional predictions, S105; pathogenesis-related protein activity, host defense-associated secondary metabolite production and, S184; PCR assay for detection of, S190; translocation of, 1278

Colletotrichum coccodes on: atypical deep lesions and, S78; natural plant volatile compounds for control of, S193

detection of seed-borne pathogens of from tubers, S75

disease-suppressive Brassica rotation crops and, S98

effects of different cropping system ap- 
proaches and water management on soilborne diseases and microbial communities, 58

fish emulsion for management of scab and yield enhancement of, $\mathrm{S} 1$

Globodera rostochiensis on, deregulation of fields formerly infested with, S22

Helminthosporium solani on: natural plant volatile compounds for control of, S193, Pseudomonas strains antagonistic against, $\mathrm{S} 257$

integrated pest management for in developing countries, S226

integrated pest management in Maine, S47

Meloidogyne spp. on: M. chitwoodi, S214; M. incognita, $\mathrm{S} 87$

new broad-spectrum fungicide for, $\mathrm{S} 184$

Pectobacterium atroseptica on, S187, S193

Phytophthora infestans on: in 2010 following 2009 epidemic, S41; Andean soils from Ecuador for suppression of S182; caspase 3-like activity and, S52; characterization of isolates (2010), S261 coinfection of by two viruses, S25 pectin methylesterase gene expression during infection, S134; potato virus S and, S105; Rpi-blb1 gene of and resistance, S69; transcriptome dynamics in response to, S58; xyloglucan-specific endoglucanase inhibitor proteins and, S85

phytoplasmas on, $\mathrm{S} 44$

Potato virus $Y$ in: in Chihuahua, Mexico, S154; distribution in plant organs, tissues, and cells, 1278

Pratylenchus spp. on, Verticillium dahliae and, S209

production of healthy seed potatoes on organic farms, S31

Pythium ultimum on, screening for resistance, S190

Ralstonia solanacearum on, characteristics of Japanese strains, S173

Rhizoctonia solani on: comparison of methods for identification of, S191; tuber postharvest dark skin spots as oversuberization response to, 436

as source of disease resistance genes for improvement of potato, tomato, and eggplant, S18

Spongospora subterranean on, evaluating spread of in storage, S60

Streptomyces spp. on: Bacillus sp. for control of, S119; characterizing suppressive soil with pyrosequencing, S156; phenazine-1-carboxylic acid production and, S9

varieties with reduced fungicide requirements, sustainable production and, S15

Verticillium dahliae on, S46, S209

virus and phytoplasma diseases of in Yunnan, China, S44

wild Solanum spp. as source of disease resistance genes for improvement of, S18

Solé, M., S168

Solenopsis mealybug. See Phenacoccus solenopsis

Solid wood packing material, introduction of exotic pests in, S217

Solorzano-Morales, A., S151

Someya, N., S116

Son, H., S100, S169

Sonder, K., S220

Song, Y., S169

Soni, R., S30

Sooty blotch and flyspeck (SBFS)

on cucurbits, S2.6

warning system for, $\mathrm{S} 2.6$

Sorghum spp.

as barrier and intercrop option against viruses in watermelon, S276

Colletotrichum sublineolum on, S140

Fusarium spp. on

diversity and pathogenicity of, S36

effect of sorghum genotype on, S243

nitrogen rate and variety selection, and disease severity and yield, S68

Pseudomonas spp. on, effect of sorghum genotype on, $\mathrm{S} 243$

Ramulispora sorghi on, disease severity, microsclerotium properties and, S19

silicon, fungicide, and anthracnose control, $\mathrm{S} 152$

Sporisorium relianum on, $\mathrm{S} 140$

Striga spp. in, S101, S232

Sosnowski, M., S14

Sosnowski, M. R., S169

Soteres, J. K., S236

Sotomayor, D., S278

Soumana, S., S232

Soungalo, S., S193

Sousa, M. C., S110

South American leaf blight. See Microcyclus ulei

Southern rice black-streaked dwarf virus

(SRBSDV), in rice, $\mathrm{S} 194$

Souza, A. C., S174

Souza, M., S43

Souza, R. M., S200

Souzani, S., S169

Sowmya, P., S145

Soybean. See Glycine max

Soybean aphid. See Aphis glycines

Soybean cyst nematode (SCN). See Heterodera glycines

Soybean dwarf virus (SbDV), tradeoffs between host adaptation and vector transmission, S176

Soybean mosaic virus (SMV) aphids and, S274

multiple loci condition seed transmission of 750

Soybean vein necrosis virus (SVNV), new soybean disease in US and, S270

Spadaro, D., S65, S66

Spaine, P., S135

Spaine, P. C., S216

Sparks, A., S170, S223

Sparks, A. N., S169

Spatial distribution, stochastic optimization method for estimation of, 1184

Spatial sampling, for detection of invasive pathogen outside of eradication zone, 725

Speers, C., S244

Spenlinhauer, T. R., S215

Spent substrates, of edible mushrooms, hot water extract from for control of cucumber diseases, S136

SPFMV. See Sweet potato feathery mottle virus

SPGVV. See Sweet potato golden vein virus

Sphaeropsis sapinea sensu lato, 334

Spiceland, D. R., S13

Spiers, J., S260

Spilocaea oleagina, on olive, sporulation $\mathrm{dy}$ namics and infection timing, S71

Spinach severe curly top virus (SSCTV), isolation

of on spinach in Arizona, S20

Spinacia oleracea (spinach)

curtoviruses in, isolation of new, S20

Fusarium oxysporum f. sp. spinaciae on, S248

Peronospora farinosa on, S52

Verticillium dahliae on, S46, S115

Spiteller, M., S18

Spliid, N. H., 960

Spodoptera spp. (armyworm)

injection of insecticides in silk channels for management of, S169

nucleopolyhedrovirus for control of, S225

Spongospora subterranean, on potato, evaluating

spread of in storage, S60

Spooner, D. M., 205, 1074

Sporisorium relianum, on sorghum, $\mathrm{S} 140$
Springer, J. C., S170

Spurlock, T., S170

Squash. See Cucurbita pepo

Squash leaf curl virus (SLCV), on melon,

watermelon chlorotic stunt virus and, 281

Sreedharan, A., S170

Srinivasachary, S., S170

Srinivasan, R., S224

Srivastava, A., S171

Srivastava, P., S170

SRNAs (small RNAs), in Xylella fastidiosa genome, S34

Srour, A. Y., S171

SSCTV. See Spinach severe curly top virus

Sseruwagi, P., S172

St. Martin, S. K., S48, S186

Staack, D., S264

Stacey, G., S150

Stack, J., S40, S65, S73, S220

Stack, J. P., S141

Stagonospora nodorum. See Phaeosphaeria nodorum

Stagonosporopsis ligulicola, on pyrethrum, S141

Stammler, G., S229, S2.7

Stangarlin, J. R., 923

Stangeland, S. K., S57

Stanghellini, M. E., 794

Stanosz, G. R., 334

Star jasmine. See Trachelospermum jasminoides

Stark, J., S15

Steadman, J., S2.7

Steadman, J. R., S278

Steciow, M., S136

Steffenson, B. J., 687

Stein, J., S2.8

Stein, J. M., S243, S246

Steiner, R., S168

Steinerma glaseri, cloning and characterization of immunosuppressive protein from surface coat of, S200

Steinlage, T. A., 750

Stemphylium solani, identification of species hosts for, S152

Stenger, D. C., S99, S171

Stephenson, A., S119

Stetzel, N. D., S2.8

Steven, C. J., S150

Stevenson, K. L., S11, S269

Stewart, J., S13, S171

Stewart, J. E., S171

Stewart, N., S174

Stewart, S., S190

Stewart, S. M., S246

Stilwell, A. R., S71

Stink bugs. See Euschistus servus; Halyomorpha halys

Stobbe, A. H., S50, S171

Stobbe, T., S41

Stocks, I., S73

Stocks, S. D., S45, S73

Stockwell, V., S26

Stockwell, V. O., S19, 113, S146, S172, S232, 299, 1234

Stoddard, T. J., S208

StojÜin, V., S22

Stoll, R., S112

Stoltzfus, J., S65

Stone, A. L., 627

Stone, J. K., S71

Stone fruits. See Prunus spp.

Stotz, H. U., 1311

Stover, E., 1097

Strathie, L., S238

Strathmann, S., S172

Strausbaugh, C. A., S172

Strawberry. See Fragaria $\times$ ananassa

Strawberry Advisory System, overview of, S140

Strawberry pallidosis associated virus, in strawberry, S229

Streams, monitoring for Phytophthora spp., S247 
Strelkov, S., S30

Strelkov, S. E., S77, S179

Strem, M. D., S272

Streptomyces spp.

for control of Phytophthora spp., S180

S. lydicus

breeding effective biological control strain of, $\mathrm{S} 107$

for control of Xanthomonas campestris pv. vesicatoria on pepper, $\mathrm{S} 154$

on potato

characterizing suppressive soil with pyrosequencing, S156

genetic and morphologic diversity of, S244 phenazine-1-carboxylic acid production and, S9

B. sp. for control of, $\mathrm{S} 119$

S. scabies

on potato, phenazine-1-carboxylic acid production and, S9

on radish, tryptophan and regulation of thaxtomin A and IAA production in, 1045

Streptomycin

Candidatus Liberibacter asiaticus and, 1097

for Erwinia amylovora, resistance and, S128, 182

Striga spp. (witchweed)

food security of Africa and, S238

plant-plant and plant-microbe interactions in rhizosphere and, S233

in sorghum, S101, S232

Strigolactones

as signals for plant-plant and plant-microbe interactions in rhizosphere, S233

Striga spp. on sorghum and, S101

tomato resistance to Phelipanche and Orobanche spp. and, 213

Striloburin fungicides

application of to winter wheat in absence of fungal disease, lack of economic benefit of, 323

plant health and, S213

Stripe rust. See Puccinia striiformis f. sp. tritici

Striped mealybug. See Ferrisia virgata

Stromberg, V., S239

Stromberger, M., S23

Strunk, C., S2.5

Stuart, J. J., S230

Su, C., S31, S41

$\mathrm{Su}, \mathrm{H} ., \mathrm{S} 172$

Suakwa aphid-borne yellows virus (SABYV), multiplex RT-PCR for detection of mixed infections with, S163

Subbarao, K. V., S10, S35, S46, S78, S115, S208,

$340,358,523$

Subere, C. V., S229

Suberization, Rhizoctonia solani on potato tubers, postharvest dark skin spots and, 436

Subramanian, S., S59, S172

Subudhi, P., S266

Sudarshana, M. R., S4, S111, S172

Sudini, H., 52, 819

Suffert, F., S65

Sufrin-Ringwald, T., 281

Suga, Y., S173

Sugano, J., S119

Sugar, D., 113, 299

Sugar beet. See Beta vulgaris

Sugarberry. See Celtis laevigata

Sugarcane. See Saccharum spp.

Sugarcane mosaic virus (SCMV), in corn, Wsm genes and, S151

Sugawara, K., S173

Sugiyama, L., S89

Sulaiman, A., S146

Sullivan, J., S69

Sullivan, R. F., S116

Sultana, V., S8, S47, S173

Sumampong, G., S248
Sun, C., S197

Sun, D., S193, S269

Sun, F.-F., 1202

Sun, J., S102, S108, S173, S198

Sun, P., 620

Sun, Q., 839

Sun, X., S41, S83

Sun, Z., S173

Sundin, G., S80, S186, S242

Sundin, G. W., S118, 182, 192, S213, S2.2, S2.6

Sunflower. See Helianthus annuиs

Sung, S., S135

Sunter, G., S173

Suo, X., S214

Suresh, S., S85

Surface plasmon resonance (SPR) technology, for detection of quarantine pathogens, S215

Surfactants, changing host environment for plant

protection purposes and, S240

Suslow, K., S85

Sussel, A. A., S174, S200

Sutherland, A., S39

Sutherland, A. M., S139, S174, S250

Sutton, T., S80

SVNV. See Soybean vein necrosis virus

Swainsonine, Undifilum spp. on locoweeds and comparison of DNA and swainsonine content, S2

detection and localization of, S152

new Undifilum sp., S14

protein extraction and proteomic analysis, S104

Swallow worts. See Cynanchum spp.

Swart, G., S37

Swart, S. H., S54

Sweany, R. R., 952

Sweet bay. See Laurus nobilis

Sweet bunden, of sugarberry, S206

Sweet cherry. See Prunus avium

Sweet orange. See Citrus sinensis

Sweet potato. See Ipomoea batatas

Sweet potato feathery mottle virus (SPFMV) detection of by one-step RT-PCR, S102 insect vector movement and, S270

Sweet potato golden vein virus (SPGVV),

infectivity in Nicotiana benthamiana, S277

Sweet potato leaf curl virus (SPLCV), infectivity

in Nicotiana benthamiana, S277

Sweet potato viruses (SPV)

detection of by one-step RT-PCR, S102

insect vector movement and, S270

phylogenetic relationships among, S102

Sweets, L. E., S200

Sweigard, J. A., S76, S273

Swett, C. L., S174

Swiecki, T., S8

Swiss needle cast. See Phaeocryptopus gaeumannii

Switchgrass. See Panicum virgatum

Switchgrass rust. See Puccinia emaculata

Sykes, V. R., S174

Symbiotic control, Xylella fastidiosa on citrus and, S96

Synchytrium solstitiale, for control of yellow starthistle, S273

Synthetic gene circuits, for plant-based detection of pathogen indicators, S178

SYP-Z048, for Monilinia fructicola, S34

Syringia spp. (lilac), Pseudomonas syringae on, S172

Sysak, R. W., S160

Systemic acquired resistance (SAR) Bacillus sereus on lily and, S248

chemical and gene technological approaches for, S233

from evolutionary perspective, $\mathrm{S} 152$

Fusicladium effusum on pecan, phosphite and, S17

glycerolipid metabolism and, S230

hypovirulent Rhizoctonia spp. and, 828

inducers of for control of Peronospora belbahrii on basil, S120
Iris yellow spot virus and, S178

methyl salicylate, salicylic acid, lipids, light and, S91

SABP2-mediated, effect of pesticide treatments on, $\mathrm{S} 94$

Szabo, L. J., S208

Szurek, B., S193

T3SS. See Type III secretion system

Tabien, R. E., S204, S205

Tadych, M., S143

Taheri, S., S174

Takach, J., S174

Takahashi, S., 567

Takamoto, H., S55

Take-all inoculum build-up (TAB), Gaeumannomyces graminis var. tritici on wheat and, $\mathrm{S} 118$

Takeshita, M., S72, S116

Takinami, Y., 567

Talaromyces sp., volatile substance from that promotes plant growth and blocks disease development, S165

Talaromyces trachyspermus, for control of Sclerotinia sclerotiorum on soybean, S2.4

Talas, F., S120

Tale Zari, A., S175

Talley, J., S188

Tally, A., S94

Tamaki, H., S173

Tamang, P., S246, S2.8

Tamarillo. See Solanum betaceum

Tamborindeguy, C., 1285

Tamo, M., S224

Tanaka, F., S75

Tanaka, S., S177

Tande, C. A., S87, S244

Tang, W., S175

Tang, X., S40, S220

Tangerine. See Citrus $x$ tangerina

Taniguchi, G., S167

Tanner, J. D., S175

Tantineni, S., S2.6

Tariq, M. R., S8

Tarnowski, T. L., S175

Taro. See Colocasia esculenta

Tatalovic, N., S175

Tatineni, S., S24

Tavantzis, S., S30

Taylor, C., S117

Taylor, C. G., S150, S185

Taylor, C. R., S65

Taylor, P. W., S175

TBDP. See TonB-dependent outer membrane proteins

TBRV. See Tomato black ring virus

TCDVd. See Tomato chlorotic dwarf viroid

TCSV. See Tomato chlorotic spot virus

Tea. See Camellia sinensis

Teaumroong, N., S200

Technology transfer, of vegetable IPM packages in India, S227

Teichmann, B., S260

Telone, for nematodes on cotton, S266

Teper- Bamnolker, P., 436

Tephritid fruit fly. See Batrocera invadens

Teplitski, M., S176, S200, S212

Termites

control of based on dummy-egg carrying behavior, S233

electronic-nose for detection and discrimination of, $\mathrm{S} 192$

Thakur, R. P., S164

Thangavelu, R., S122

Thannhauser, T., S63

Thatching grass. See Hyparrhenia rufa

Thaveechai, N., S44

Thaxtomin A, and Streptomyces scabiei in radish, 1045

Thecaphora amaranthi, on amaranth, S123

Theobroma cacao (cacao), Moniliophthora spp. 
on, S272, S274

Thielaviopsis basicola on cotton, S111, S209

on soybean, S27, S38

Thies, J. A., S176

Thines, M., S149

Thiruvudainambi, S., S42

Thomas, A., S269

Thomas, D., S94

Thomas, J. E., S65

Thomas, K., S135

Thomas, S., S168, S176

Thomashow, L., S117

Thomashow, L. S., S201, S231, 996, 1481

Thomma, B. P., S208

Thompson, D. C., S176

Thomsen, I. K., 960

Thorkelson, J., S36

Thornton, M., S15

Thorpe, D. J., 555

Thousand cankers disease. See Geosmithia morbida

Thrips. See also Frankliniella spp.

identification system for in East Africa, S59

mulches for management of, S130

on onion, resistance against, S17

Peanut bud necrosis virus in tomato and, S210 and plant pathogenic fungi in mango inflorescences, S255

seaweed extract for control of on peppers, cucumbers, and Hass avocadoes, S126 on tomato, influence of control programs on Tomato spotted wilt virus incidence, $\mathrm{S} 250$

Thunbergia laurifolia (clock vine), Alternanthera mosaic virus in, $\mathrm{S} 182$

Thuy, P. T. H., 231

Thuy, T. T. T., 231

Ti plant. See Cordyline fruticosa

Tiadinil, for induction of systemic acquired resistance, $\mathrm{S} 233$

Tian, B., S176

Tian, S., S176

Tian, T., S195

Tian, Y. P., 377

Tibetan Plateau, forest diseases, insects, and integrated pest management in, S33

Tiedemann, A. von, 1355

Tilletia spp., on wheat, S13

Timchenko, T., S64

Timko, M., S239

Timmer, L., S171

Timmerman, A., S2.5

Timmons, C., S43

Timper, P., S266

Tisserat, N., S17, S55, S138, S168, S201, S247

Tisserat, N. A., S168, S178

Tittabutr, P., S200

Tjosvold, S., S177

Tkachi, N., S131

Tobacco. See Nicotiana spp.

Tobacco mosaic virus (TMV)

ethylene-response factor 5 and, S198

as expression vector in coffee, $\mathrm{S} 7$

mulches for management of insects vectoring, S130

in tobacco, control by PopW from induced resistance in, 1202

Tobacco rattle virus (TRV), in Dicentra spec-

tabilis, molecular characterization of, S154

Tobacco streak virus (TSV), gene silencing vector

from, soybean seed development and, S86

Tobiasz, M., S258

ToCLV. See Tomato leaf curl virus

ToCV. See Tomato chlorosis virus

Toda, T., S56

Togola, A., S130

Toh, R., S238

Tojo, M., S177

Tokuda, M., S94, S177

ToLCPEV. See Tomato leaf curl Peru virus

Toleubayev, K., S177
Tolin, S. A., S161, S210

Tomaso-Peterson, M., S61, S85, S177

Tomato. See Solanum lycopersicum

Tomato black ring virus (TBRV), influence of defective RNAs on symptom expression, S18

Tomato chlorosis virus (ToCV), in cucurbits in Costa Rica, S151

Tomato chlorotic dwarf viroid (TCDVd), in tomato, deep sequencing for identification of, S106

Tomato chlorotic spot virus (TCSV), on tomato, S189

Tomato golden mosaic virus (TGMV), in tobacco, $\mathrm{S} 173$

Tomato leaf curl New Delhi virus (ToLCNDV), in melon, factors controlling mechanical transmissibility of, $\mathrm{S} 30$

Tomato leaf curl Peru virus (ToLCPEV), in tomato, S119

Tomato leaf curl virus (ToCLV), weeds as reservoir hosts of, $\mathrm{S} 94$

Tomato mosaic virus (ToMV), in eggplant, in Iran, S3

Tomato necrotic spot virus (ToNSV), in central valley of California, S13

Tomato ringspot virus (ToRSV) elimination of by in vitro therapy, S81 in rose and almond, $\mathrm{S} 160$

Tomato spotted wilt virus (TSWV) characterization of vsRNAs derived from, S93 genetic based population analysis of nucleocapsid protein of, S55

Iris yellow spot virus and, in datura, genetic complementation between, S12

in lettuce, nucleocapsid protein gene for pathogen-derived resistance in, $\mathrm{S} 3$

mulches for management of insects vectoring, S130

in peanut

in North Carolina and Virginia, 147

production practices, cultivar selection, and incidence of disease and yield of, S68 in planta expression of glycoprotein of, $\mathrm{S} 123$

in solanaceae of Georgia, S125

in tobacco, loss caused by in winter, 462

in tomato, influence of thrips control programs on, S250

using host resistance genes for control of, S75 western flower thrips and, differentially expressed proteins in response to, $\mathrm{S} 12$

Tomato yellow fruit ring virus (TYFRV), on peanut, S62

Tomato yellow leaf curl China virus (TYCCNV) causes of genetic diversity in, S203 RNAi-mediated silencing and, S207

Tomato yellow leaf curl virus (TYLCV) Bemisia tabaci feeding behavior and spread of, 1191

identification of in China, S82

on tomato, S109

on watermelon, S122

Tomich, J. M., S12

Tomitaka, Y., 316

TonB-dependent outer membrane proteins (TBDP),

of Pseudomonas fluorescens, S70

Tonnang, H., S57

Tonolla, M., S145

Tooley, P. W., S274

Toona ciliata (cedar), Xanthomonas spp. on, S200

Torres, G. A., S254

Torres, J., S278

Torres, R., S99

Torres de Matute, O., S222

Torres-Barragan, A., S178

Torreya taxifolia, soilborne pathogens as cause of decline of, $\mathrm{S} 255$

ToRSV. See Tomato ringspot virus

Tory, D., S94

Tospoviruses artificial microRNAs for engineering resis- tance against, S121

broad spectrum resistance in transgenic tobacco and tomato against species of different serogroups, S140

in Hymenocallis littoralis and Hippeastrum vittatum in China, S51

in vegetables, importance and genetic diversity of in India, 367

Toth, I., S186

Townshend, J. M., S178

Toyoda, K., S165

Trachelospermum jasminoides (star jasmine),

Phytophthora ramorum on, $\mathrm{S} 134$

Trade. See Import regulations; Quarantine

Trail, F., 1091

Tran, P., S178

Transgenic crops. See also Genetic engineering

an ethical look at, S237

papaya, Papaya ringspot virus resistance and, S237

for pest management, impact of on environment and food safety, S226

squash, S237

tomato, resistance to Xanthomonas spp. and resistance gene from pepper, S237

Translational biology, for deployment of disease resistance traits, $\mathrm{S} 237$

Traore, H., S232

Travadon, R., S14, S156, S178

Travers, S. E., S5

Trebicki, P., S53

Tredway, L. P., S111, S147, S267

Tree-of-heaven. See Ailanthus altissima

Tremblay, A., S209

Trialeurodes vaporariorum (whitefly) criniviruses in multiple crops in Costa Rica and, S151

geminiviruses in pepper and, S150

temperature-dependent development and reproduction of, S57

Triapitsyn, S., S59

Triazole fungicides, application of to winter wheat in absence of fungal disease, lack of economic benefit of, 323

Trichoderma spp.

T. asperellum, for control of Phytophthora ramorum in nursery soil, $\mathrm{S} 191$

for control of Sclerotinia sclerotiorum, on bean, S109

T. harzianum

L-amino acid oxidase isolated from, S108, S251

Botrytis cinerea and, S106

chrysophanol and pachybasin from, S106

interaction with Fusarium solani f. sp. pisi, S91

novel glucanases from, S248

heat shock response in, $\mathrm{S} 145$

T. koningi, genes in from Metarhizium anisopliae, S33

on peach, S197

screening strains of for decomposition of agriculture wastes, S109

$T$. virens, for potato disease management, S30

Trichogramma dendrolimi, for control of Asian corn borer, S39

Trichothecenes

Fusarium graminearum and, 929

and population genetic analysis of Gibberella zeae from barley, 687

Tricyclazole, sensitivity of Magnaporthe grisea to, S45

Trifloxystrobin, for Cercospora zeae-maydis on corn, S31

Trifolium spp. (clover)

Red clover necrotic mosaic virus in, S137

Soybean dwarf virus in, S176

Triforine, for Monilinia vaccinii-corymbosi on

blueberry, S176

Trigiano, R., S260 
TriMV. See Triticum mosaic virus

Trioza erytreae (African citrus psyllid), Candidatus Liberibacter ssp. and, S10

Tripathi, D., S178

Tripathi, M., S164

Triplett, E., S77

Triplett, L., S193

Triplett, L. R., S178, S183

Trippe, A., S134

Tristeza. See Citrus tristeza virus

Triticale, Blumeria graminis on, analysis of

interaction between, S53

Triticum aestivum (wheat)

application of fungicide to in absence of fungal disease, lack of economic benefit of, 323

assessment of seed treatments for protection against biological winterkill in, S73

Bacillus amyloliquefaciens for control of

Fusarium graminearum on, S39

Blumeria graminis on

in China, S45

Puccinia triticina and $\mathrm{N}$-deficiency and, $\mathrm{S} 22$

cereal cyst nematodes on, species and pathotype identification, $\mathrm{S} 102$

Cochliobolus sativus on

collection of isolates and assessment of virulence pattern, $\mathrm{S} 2.8$

virulence variability and genetic diversity of, S5

effects of viruses of on supply and demand, S53

fluctuations in diseases in North Dakota, 2004-2010, S2.6

fungi associated with roots and crowns of diseased, S277

fungicide application on disease-resistant strains, S132

fungicide application to in absence of fungal disease, lack of economic benefit of, 323

Fusarium spp. on

F. culmorum, in Idaho, $\mathrm{S} 16$

F. graminearum: climate, weather, and heterogeneity of, S221; Clonostachys rosea strain ACM941 for control of S194; Cryptococcus flavenescens, triazole fungicides and, S160; deoxynivalenol biosynthesis-related gene expression during colonization by, 1091; molecular and phenotypic variation of German populations, S120; transcriptome analysis of infection by different chemotypes, S52

nivalenol-type populations, 124

F. pseudograminearum: fungal community analysis through ITS sequencing, S73;

QTL for resistance, S144; simple model for management of, S12

Gaeumannomyces graminis var. tritici on, S118, S201, 1481

gall-inducing leafhopper on, effect of barley

chromosome addition, S94

Gibberella zeae on

biological control agents for, S200

cytological alterations induced by combinatorially selected defense peptides, S65 fungal mating pheromone peptides and S199

growth in water limited cropping systems, food security and, S226

Heterodera filipjevi on, S196

identification of pathogens causing root rot

diseases of in China, S82

inoculation methods for evaluating root pathogens of, S246

integrated pest management for in Oklahoma, S157

Locusta migratoria on, effect of barley chromosome addition, $\mathrm{S} 177$

Magnaporthe spp. on

$M$. grisea: international perspective on,
S220; risk mapping potential in Brazil, $\mathrm{S} 221$

M. oryzae: gene flow levels 20 years after first epidemics, S221; resistance among US cultivars, S220; standardization of protocols to test for, S40; susceptibility of select US cultivars, S141

Mycosphaerella graminicola on

chromosome dynamics, genome evolution, stealth pathogenesis of, S208

fungicide mixing, resistance and, 1224

genetic differentiation at microsatellite loci among populations, 1251

genetic population structure of, S243

QTL for adult-plant resistance, 1209

Oculimacula spp. on, S165

penthiopyrad uptake and translocation and, S141, S142

Phaeosphaeria nodorum on, association mapping of resistance in USDA National Small Grains Collection, 1301

powdery mildew on, detection with hyperspectral remote sensing, S26

PROCULTURE model and, S47

Pseudomonas syringae on, field evaluation for resistance, $\mathrm{S} 2.4$

Puccinia spp. on

P. graminis f. sp. tritici: management strategies using fungicides, S243; resistance to Ug99 race group, S127; Ugg lineage of, S132

novel resistance against, $\mathrm{S} 25$

$P$. striiformis: in China and US, virulence and molecular comparison, S201; comparison of old and new strains, S121; evaluation of varieties for host resistance, S26; Lankao 5 strain and resistance, S147; mapping of new genes for resistance, S205; phenotyping resistance and virulence, S121; predicting potential yield loss, 544; race variation in China, S83; virulence diversity of international collections of, S164

$P$. triticina: foliar fungicides and, S265 genetic differentiation of populations, 870; race and virulence dynamics in China, S33

Pyrenophora tritici-repentis on

QoI-resistant populations, S2.7

QTL contributing resistance against, S2.7

Pyricularia grisea on, S264

Rhizoctonia spp. on, S161

Rhopalosiphum padi on, arbuscular mycorrhizae and, S2

Soilborne wheat mosaic virus in, 1322

Stagonospora nodorum on, S191, 1278

Tilletia spp. on, S13

Triticum mosaic virus in, S24, S2.2, S2.6

wheat curl mite on, virus transmission by, S71

Wheat streak mosaic virus in, S24, S2.2, S2.5

Xanthomonas campestris pv. translucens on

quick identification of, S244

yield loss in spring wheat and, S87

Triticum monococcum, genetics of resistance to race TTKSK of Puccinia graminis f. sp. tritici on, 1418

Triticum mosaic virus (TriMV)

detection and discrimination of, S9

in wheat

transmission of by wheat curl mite, S71

wheat curl mite and, S2.6

Wheat streak mosaic virus and, S24, S2.2

Trivedi, P., S4, S178

Trivedi, R. S., S178

Trogolo, J. A., S259

Tronsmo, A., S239

Trotel-Aziz, P., 768

Trouillas, F. P., S179

Truffles, identification, hosts, distribution, and

molecular phylogeny of, S81
Trujillo, C. A., S179

Trumble, J., S113

Truong, H., S186

TRV. See Tobacco rattle virus

Tryptophan, regulation of thaxtomin A and IAA

production in Streptomyces scabiei and, 1045

Tsai, C., S76

Tsai, T.-C., S264

Tsror, L., S241

Tsror, Lahkim, 436

Tsuchiya, K., S56, S72, S95, S116, S173, S179, S188

Tsuda, K., S208

Tsuda, S., 316

Tsuda, Y., S208

Tsuga spp., Armillaria spp. on, S258

Tsui, C., S51

Tsujita, N., S177

Tsukiboshi, T., S173

Tsushima, S., S56, S95, S179

TSWV. See Tomato spotted wilt virus

TTKSK race. See under Puccinia graminis f. sp. tritici

Tu, Z., S29, S58

Tufan, H. A., S220

Tuinstra, M., S232

Tulam, V., S10

Tumlinson, J. H., S16

Tumuluri, R., S10

Turechek, W. W., 1366

Turfgrasses. See also Individual species

Cochliobolus sp. on, S177

Colletotrichum cereale on, S111, S187, S259

fungicides for management of diseases in, S211

Magnaporthe spp. on

M. grisea, 85

M. poae, $\mathrm{S} 204$

new broad-spectrum fungicide for, S259

Ophisphaerella korrae on, S177

Poculum sp. isolated from in Florida, S39

Sclerotinia spp. on

S. homeocarpa: characterization and distribution of mating type genes of, S147; demethylation inhibitor fungicides, plant growth regulators and, S25; DMI exposure and resistance, S267; earlyseason fungicide application and, S79, S192; effects of fungicide timing and post-application irrigation on, $\mathrm{S} 87$; effects of light-weight rolling on, S2.3; effects of temperature on, S192, S2.9; initial inoculum and, S153; microsatellite markers for, S147; ningnanmycin for control of, S111; propiconazole-resistant, S262; Pseudomonas aureofaciens for control of, S2.9; use of temperature and relative humidity variables to predict fungicide application for, S268

$S$. sclerotiorum, genetic diversity and heterothallism in, $\mathrm{S} 104$

silvery threadmoss in, biological control of, $\mathrm{S} 144$

Typhula ishikariensis on, fludioxonil, propiconazole, chlorothalonil sensitivity and, S17

Waitea circinata on, S35, S129

Turini, T. A., S179, S250

Turkington, T. K., S179, S180

Turnbull, G., S30

Turnbull, G. D., S77

Turner, J., S53

Turner, R. S., S114

Tušek Žnidaric, M., 1292

Tweddell, R. J., S257, S261

Twieg, E., S106

TYCCNV. See Tomato yellow leaf curl China virus

Tychon, B., S47

TYLCV. See Tomato yellow leaf curl virus

Tyler, B. M., S230

Tylka, G. L., S42, S175, S191, S209

Tymon, L. S., S180 
Tymon Putnicki, L. S., S251

Type III secretion system (T3SS)

bioinformatics for study of, S145

of Dickeya dadanti, S206

Erwinia amylovora on tobacco and, S197

Xanthomonas axonopodis pv. manihotis on cassava and, S152

Typhula ishikariensis

in changing environment and molecular basis for interactions with plants, S239

on turfgrass, fludioxonil, propiconazole, chlorothalonil sensitivity and, $\mathrm{S} 17$

Tzanetakis, I., S87, S206, S268, S270

Tzanetakis, I. E., S70, S97, S145, S158, S229

Tzeng, D., S76, S180

Tzeng, K., S31, S76

Tzeng, Y., S41

Uchida, J., S146, S180, S215

Uchida, J. Y., S127, S165

Uematsu, S., S6

Uganda cassava brown streak virus (UCBSV), occurrence and diversity in Tanzania, 1159

Ugg lineage. See under Puccinia graminis f. sp. tritici

Ukwungwu, M., S130

Ulhoa, C. J., S109

Ulloa, M., S187

Umbellaria californica (California bay), Phytoph-

thora ramorum on, $\mathrm{S} 177$

Umbrella magnolia, Magnolia mosaic virus in, S158

Umetsu, N. K., S233

Uncinula necator. See Erysiphe necator

Undifilum spp., on locoweeds

new swainsonine-producing species, S14

U. oxytropis

detection and localization of, S152

proteomic analysis of, $\mathrm{S} 104$

swainsonine content and, S2

University of Maryland Plant Diagnostic Labora-

tory, woody host plant problems diagnosed in 2008-2010, S117

Upadhyaya, H. D., S164

Urashima, A., S180

Urban forestry education, global food security

short courses for enhancement of, S38

Urbez Torres, J. R., S180

Urea sprays, for Venturia inaequalis on apple, S262

Uredo rangelii (myrtle rust), on myrtaceae, S72

Uromyces spp.

U. appendiculatus, on bean, S138, S245, S2.7

$U$. transversalis, on gladiolus, $\mathrm{S} 181$

Urushibara, T., S13

Usami, T., S6, S88

Ustilaginoidea virens (false smut), on rice, crop rotation, soil tillage and fertility and, S7

Ustilago spp.

U. maydis

on corn, drydown rates, environmental factors, and resistance, $\mathrm{S} 251$

as model system for study of glycolipid gene cluster in Pseudozyma flocculosa, S260

U. nuda, on barley, rapid detection of, $\mathrm{S} 10$

Usugi, T., 316

Utomo, H., S266

Uyemoto, J. K., S4, S172

Uzuhashi, S., S177

Vaccinium spp.

V. corymbosum (blueberry)

black shadow disease on, S143

Blueberry necrotic ring blotch virus in, $\mathrm{S} 115$

Botryosphaeria dothidea on, S194

Cladosporium spp. on, epiphyte populations and, S99

Colletotrichum acutatum on, antifungal compounds in resistant cultivar, S120
Diaporthe/Phomopsis complex associated with, S99

Lasiodiplodia theobromae on, S194

Monilinia vaccinii-corymbosi on, S176

Neofusicoccum ribis on, $\mathrm{S} 194$

Phomopsis spp. on, S99

Phytophthora spp. on, S167

Xylella fastidiosa on, improving PCRbased detection of, S37

V. macrocarpon (cranberry)

fruit rot resistance and heritability in, S143

Phytophthora cinnamomi on, Chromobacterium sensu lato for biological control of, $\mathrm{S} 168$

$V$. reticulatum (ohelo), powdery mildew resistance and, S89

Vadamalai, G., S85

Vaira, A., S126, S181

Valdivia, C., S62

Vale, F. X., S123, S155

Valencia-Botín, A., S181

Valent, B., S40, S220

Valent, B. S., S141

Valente, A. A., S181

Valkonen, J. P. T., 377

Vallad, G. E., S269, S270, 523

Vallance, J., S21

Valls, M., S168

Valverde, R., S181

Valverde, R. A., S158

van den Bosch, F., 725, 1184, 1224

van der Knaap, E., S41

van Dusschoten, D., S72

Van Ghelder, C., 945

van Heusden, A. S., S51

Van Nostrand, J. D., S178

Van Ryzin, B., S153

Van Twest, S. M., S251

Vance, C. P., S29

Vandemark, G., S148

Vandervoort, C., S120

Vangessel, M., S181

VanKirk, J., S161

Vannini, A., S7, S182

VanOverbeke, M., S63

Varga, A., S248

Vargas, J., S151

Vargas, J. M., S2.3

Vargas, M., S162

Varon, F., S254

Varrelmann, M., 718, 1330, 1338

Vaughan, L., S182

Vaz, M., S254

Vázquez, D. A., S279

Vázquez-Jiménez, J., S133

VBP, in Agrobacterium tumefaciens, S58

Vega, B., S182

Vega-Arreguin, J., S230

Vegetative compatibility groups (VCG)

of Aspergillus flavus on corn, S250

and Colletotrichum acutatum on different hosts, 923

of Cryphonectria parasitica on chestnut, S170

of Fusarium oxysporum f. sp. cubense on banana, S43, S122

in soil and corn kernel Aspergillus flavus populations, 952

of Verticillium dahliae

on olive, 304

phylogenetic relationships among, S83

on potato and mint, $\mathrm{S} 46$

on sunflower, $\mathrm{S} 4$

Velázquez-Monreal, J., S133

Velez, D. C., S254

Velini, E. D., S8

Velvet bean caterpillar. See Anticarsia gemmatalis

Vemmer, M., S182

Vemulapati, B. M., S182

Venette, R. C., 404

Venkatesan, S., S85
Venturia inaequalis, on apple

genetic diversity and temporal dynamics, S83

integrated pest management and fungicide resistance and, S213

multiple fungicide resistance and, $\mathrm{S} 128$

post-harvest foliar urea sprays for, S262

rapid detection of fungicide resistance, $\mathrm{S} 2.3$

seasonal distribution of fungicide resistance, S114, S274

survey of fungicide resistance, S242

tank mixing of dodine for, $\mathrm{S} 80$

$V$-resistant cultivars and, $\mathrm{S} 14$

Vera Cruz, C. M., S182

Vercauteren, A., 166

Verdejo- Lucas, S., 410

Verdier, V., S183, S193

Verdier, V. M., S168

Verhagen, B., 768

Vericompost tea, for control of Phytophthora nicotianae on pineapple, S167

Vernaiz, M., S183

Vernière, C., 887

Veronese, P., S208

Veronica anthelmintica, for control of Meloidogyne javonica, $\mathrm{S} 173$

Verstappen, E., S18

Verstraten, J., S191

Verticillium spp.

V. albo-atrum

ATG8 autophagy gene of, S251

comparative genomic analysis of, S208

lucerne and non-lucerne isolates of, $\mathrm{S} 88$ on tree-of-heaven, S89

$V$. chlamydosporium, for control of Meloidogyne incognita, 92

$V$. dahliae

ATG8 autophagy gene of, S251

on broccoli and cauliflower, phenological and phytochemical changes correlating with, 523

on cabbage, quantitative detection in soil, S13

comparative genomic analysis of, S208

genes involved in microsclerotia development of, S250

leguminous cover crops as hosts for, S109

on mint, S46, S247

on olive, 304

on peppermint, S247

phylogenetic relationships among vegetative compatibility groups, $\mathrm{S} 83$

population structure of, ancient split in evolutionary history and, S10

on potato, S46, S209

on skullcap, S247

on spinach, S46, S115

on strawberry, S261

on sunflower, S4, S241

on tomato, grafting for management of, S79

$V$. longisporum, on cabbage, quantitative de-

tection in soil, $\mathrm{S} 13$

species limits of, S78

Vetch. See Astragalus sinicus

Vetten, H., S64

Vf gene, and apple against Venturia inaequalis, S14

Viaud, M., 1433

Viburnum spp.

emaravirus and cryptovirus infection of, S158

Phytophthora ramorum on, test system for quantifying inoculum in runoff from infected plant roots, 1457

Vicent, A., 1346

Vicia faba (faba bean)

Didymella fabae on, S135

Fusarium avenaceum and Rhizoctonia solani on, fungicide seed treatments for, S30

Vick, A., S11

Vick, B. A., 241

Vico, I., S86, S141, S183 
Victorivirus spp., termination-reinitiation strategy for downstream ORF translation in, S101

Vidalakis, G., S2, S49, S69, S87

Vieira, M. L. C., 416

Vigne, E., S63

VIGS. See Virus-induced gene silencing

Vilchez, M., S54

Vilela, C. M., S8

Viljoen, A., S18, S122

Villalobos, W., S255

Villamarín, D., S133, S183

Villani, S. M., S128

Vinatzer, B., S69

Vinatzer, B. A., 847

Vinca (annual). See Catharanthus roseus

Vincelli, P., 1122

Vincetoxicum spp. See Swallow worts

Vine decline. See Monosporascus cannonballus

Viroids

in oil palm, S85

replication of in citrus protoplasts, S69

in stone fruit trees, detection of, S105

in tomato, deep sequencing for identification of, S106

Virulence groups, in Fusarium oxysporum f. sp.

phaseoli, on bean, 470

Virus-induced gene silencing (VIGS)

for assessing gene function in cotton plant, S21

for identification of genes involved in host basal defense to Clavibacter michiganensis subsp. michiganensis, 349

Phakopsora pachyrhizi on soybean and, S139

Tobacco streak virus-based vector for soybean seed development, S86

Virus-like particles, as chemical bio-conjugate substrates, S126

Vital, K., 887

Vitale, S., 679

Vitebio.net, downy mildew in vineyards and, S24

Vitis spp. (grape)

Agrobacterium vitis on

nontumorigenic $A$. vitis strain $\mathrm{F} 25$ for control of, S86

phosphopantetheinyl transferase gene and necrosis, $\mathrm{S} 23$

Arabis mosaic virus in, $\mathrm{S} 44$

Aspergillus spp. on, novel fruiting structure produced by, $\mathrm{S} 142$

Botrytis cinerea on

characterization of $B s l$ genes in response to, S250

epiphytic yeasts for biocontrol of, $\mathrm{S} 162$

fenhexamid resistance and, S158

multidrug resistant, promoter rearrangements and, 1176

R2R3MYB transcription factor and, S163

Botrytis pseudocinerea on, Botrytis cinerea and, 1433

Colletotrichum gloeosporioides on, identification and virulence differentiation, $\mathrm{S} 103$

effect of downy and powdery mildew on, S11

Elsinoe ampelina on, S26, S169

eradicating exotic diseases on, S169

Erysiphe necator on

chasmothecia development and dispersal, S203

effect of acute low temperature events on, S14

effect of UV-A and UV-B on airborne conidia concentrations, S196

inoculum detection for timing of fungicide application and, S249

LAMP assays for detection of, S112

Ren4 locus and resistance to, 502

time lagged effects of weather variables on airborne spore concentrations, S197

visual scouting, spore trapping systems, and bioindicators for detection of, S139

volatile organic compound emission and, S174
Esca-related pathogenic fungi in, S21

Eutypa lata on, S14, S156

grapevine leafroll disease of, effects of on

anthocyanins and flavonoids, S67

Grapevine leafroll-associated viruses in genetic diversity in $3^{\prime}$ terminal region of, 445

as genetically diverse population, 1446

grapevine trunk diseases on in British Columbia, S180

Grapevine vein clearing virus in, S202, 1081

Guignardia bidwelli on, S169

Hanseniaspora uvarum on, S259

Lasiodiplodia theobromae and Diplodia seriata on, pycnidial development, pycnidiospore germination and, S39

Phomopsis spp. on, S56, S221

phytoplasmas on, new approach to management of, S156

Planococcus ficus on, mating disruption for control of, S120

Psyllobora vigintimaculata on, effects of fungicide on, S250

sour rot of in Niagara region, S259

trunk diseases of, $\mathrm{S} 42$

Xiphinema spp. on, genetic population structure based on mitochondrial DNA variation, 1168

Xylella fastidiosa on

alg $U$ gene and, S165

assessment of movement process in susceptible and resistant cultivars, 77

biofilm formation and, S141

characterization of chemosensory gene cluster in, S10

FRET probe genotyping of, S18

lipopolysaccharide and virulence and host specificity of, S38

metabolic profiling of susceptible and resistant lines, S107

modeling cold curing of in California, 1492

proteomic analysis of host response to, S105

role of egestion in the inoculation mechanism of foregut-borne plant pathogens and, 912

secondary metabolite and defense-related protein levels in xylem and, S185

yeasts associated with sour rot of, S189

Vitiviruses, novel isolated from currants, S154

Vitoreli, A., S183

In vitro therapy, for elimination of small fruit viruses, $\mathrm{S} 81$

Vivancos, J., S183

VOC. See Volatile organic compounds

Vogel, G., S145

Voisin, R., 945

Volatile organic compounds (VOC)

of Candida intermedia, for control of Botrytis cinerea on strawberry, 859

of Ceratocystis fimbriata on, on pomegranate, $\mathrm{S} 103$

for control of potato blemish disease pathogens, S193

Erysiphe necator on grape and, S174

Fusarium oxysporum on Arabidopsis thaliana and, S16

green leaf volatiles, as plant defense mechanism, S48

plant-parasite interactions and, S231

produced by grape infested with glassywinged sharpshooter, S184

Voldeng, H., S195

Von Dahl, C., S92

von Tiedemann, A., S220, 1338

Vorhoelter, F., S144

Vorsa, N., S143

Voss, K. A., S222

Vossbrinck, C. R., S260

Vu, A. L., S121, S184
Waalwijk, C., S43

Wada, T., S49

Wade, L., S2

Waitea circinata

on bentgrass and bluegrass, S35

on turfgrass, microsatellite markers for population genetic analysis, S129

Wajnberg, E., 679

Wakefield, L., 839

Walcott, R., S183, S265

Waldstein, D., S2.6

Waldstein, D. E., S184

Walgenbach, P., S184

Walker, A.-S., 1176, 1433

Walker, D. R., S58

Walker, E., 1278

Walker, K. L., S218

Walker, M. A., S105, S107

Walker, N. R., S211

Walker, S., S51, S172, S184

Wall, M. M., S129

Wallis, C., S184, S185

Wallon, T., S98

Walnut. See Juglans nigra

Walnut blight. See Xanthomonas arboricola pv. juglandis

Walnut twig beetle. See Pityophthorus juglandis

Walse, S., S184

Walsh, C. S., S69

Walsh, D. B., S144

Walsh, E. K., S185

Walter, A. J., S6

Walter, N., S117

Walters, T., S248

Walters, T. W., S218

Wan, A., S198, S201

Wan, F., S185

Wan, Y., S31

Wang, B., 377

Wang, C., S37, S187

Wang, D., S44, S49, S140, S186, S187, S198, $710, \mathrm{~S} 2.8$

Wang, G.-L., 620

Wang, H., S48, S100, S173, S185, S186, 1217

Wang, I., S187

Wang, J., S58, S107, S186, S199, S225, 445, S2.8

Wang, J.-F., 154

Wang, K., S113, S185, S187

Wang, L., S82, S93, S104, S194

Wang, M., S201, S205

Wang, N., S4, S67, S75, S76, S80, S84, S101,

S138, S170, S178, S181, S196

Wang, P., S2

Wang, Q., S34, S71, S108

Wang, R., S187, S198

Wang, S., S125, S207, 620

Wang, T., S76, S188

Wang, W., S198

Wang, X., S39, S41, S186, S187, S207

Wang, Y., S187, S188, 620, 750

Wang, Z., S107

Wanner, L. A., S188

Wanobi, O. O., S131

Wanyera, R., S127

Warburton, M., S21

Ward, N. A., S268, S269

Ward, N. B., S157

Ward, T. J., 124

Wardzynski, M., S191

Warkentin, D., S184

Warner, F., S2.8

Warner, F. W., S160

Warnstrom, E. L., S188

Warr, M., S269

Warren, J., S188

Warriner, K., S217

Warshavsky, S., 436

Wasala, L., S188

Watanabe, H., S188

Watanabe, S., S20 
Water lettuce. See Pistia stratioles

Waterhemp. See Amaranthus spp.

Watermelon. See Citrullus lanatus

Watermelon bud necrosis virus (WBNV), on

vegetables, in India, 367

Watermelon chlorotic stunt virus (WmCSV) on melon, Squash leaf curl virus and, 281 on watermelon in Iran, S122

Waters, C. M., S2.2

Watkins, C. B., S262

Watrin, C., S132

Watson, A., S189

Watters, H., S73

Way, M. O., S205

Wayadande, A., S7, S188

WBNV. See Watermelon bud necrosis virus

Weather input errors, and decision aids for multiple-decision disease management, 644

Weaver, M., S1

Webb, K. M., S182, S2.5

Weber, B., S114

Webster, B. J., S60

Webster, C. G., S189

Wechter, W., S189

Wechter, W. P., S106

Weed risk assessment, need for, S237

Weeds

emerging threats, climate change and, S240

fluorescent spectra and lifetime of, impacts of selected herbicides on, S77

invasive as threat to agriculture and human health, S237

parasitic, dangers of, S238

Weems, J. D., S189, S246

Wegulo, S. N., S24, S2.2

Wei, G., S125

Wei, L., S189

Wei, S., S170

Wei, W., S214, S272, S273, S275

Wei, Y., S107, S189, S204

Wei, Z., S106

Weiland, J. J., S47

Weinberger, K., S225

Weiss, B., 416

Weiss, R. M., S179

Weisz, R., 323

Welker, R. M., S45, S79

Weller, D., S117

Weller, D. M., S201, S231, 1481

Welliver, R., 627

Wells, L., S68

Wen, A., S190

Wen, L., S202

Wenner, N., 1091

Werbiski, R., S262

Werle, R., S2.9

Werres, S., S65, 166

Wessel-Beaver, L., S276

Westerdahl, B. B., S190

Western bark beetle. See Pseudopityophthorus agrifola

Western flower thrips. See Frankliniella occidentalis

Western rootworm. See Diabrotica virgifera

Westphal, A., 878

Westwood, J., S228, S239

Weyns, J., 1149

Wharton, P. S., S15, S190, S193

Wheat. See Triticum aestivum

Wheat curl mite. See Aceria tosichella

Wheat streak mosaic virus (WSMV)

in corn, Wsm genes and, S151

sensitive detection and discrimination of, S9

SNP genotyping method for, S155

in wheat

North Dakota 2010 outbreak, S184

spring inoculated winter wheat lines, S2.5

transmission of by wheat curl mite, S71

Triticum mosaic virus and, S2.2

Wheat streak mosaic virus and, S24
Wheeler, T. A., S270

Whitaker, B. D., S86

White, D., S104

White, J., S143

White, N., S49

White pine blister rust. See Cronartium ribicola

Whiteflies. See Bemisia tabaci; Trialeurodes vaporariorum

Whitfield, A., S9

Whitfield, A. E., S12, S123

Whitham, S. A., S139

Whitworth, J. L., S190

Wick, H. C., S263

Wick, R. L., S258, S263

Wicker, E., 154

Wickett, N., S239

Wickland, A. C., 492

Wickramasinghe, D., S190

Wicks, T. J., S169

Widmer, T. L., S146, S191, S273

Wiechel, T. J., S191

Wiggs, S. N., S191

Wijeratne, A., S186

Wijeratne, S., S186

Wikipedia, editing in to learn concepts in plant pathology, S70

Wilcox, W., S156

Wilcox, W. F., S158, S169, S228

Wild rice. See Zizania palustris

Wildung, M., S77

Wilkinson, H. T., S54

Williams, B., S86

Williams, K., S117

Williams, S., S93

Willocquet, L., S170, S223, 696

Willyerd, K., S170

Willyerd, K. T., S191

Wilson, A., S192

Wilson, C., S268, S2.9

Wilson, C. M., S192

Wilson, L. T., S205

Wilson, R., S149, S2.8

Windels, C. E., S19, S153

Windham, A., S16, S260

Windham, M., S16, S260

Windham, M. T., S174

Wingfield, B., S215

Wingfield, M., S204

Wingfield, M. J., S140, S215

Wingo, R., S174

Wininger, S., 213

Wintermantel, W. M., S158, S192

WISDOM, for predicting potato late blight epidemics, S247

Wise, K., S191

Wise, K. A., 1122, S2.8

Witches broom phytoplasma on coffee, S276 on purple coneflower, S139

Witchweed. See Striga spp.

Witherell, R. A., S114

Wittmer, L. M., S274

WmCSV. See Watermelon chlorotic stunt virus

Woeste, K., S201

Woin, N., S130

Wolcan, S. M., S136

Woldemariam, T., S252

Wolf, I., S136

Wolf, S., S90

Woloshuk, C. P., 797

Wong, F., S129

Wong, F. P., S35, 85, S229

Wong, M., S192

Wongkaew, S., S200

Wonni, I., S193

Wood, B. W., S17, S193, S196

Wood, E., S193

Wood, M., S63

Wood packaging. See Solid wood packing material

Woodell, L., S190
Wood-Jones, A. K., S193, S269

Woodruff, W., S135

Woodward, J., S193, S266

Woodward, J. E., S270

Worapong, J., S59

Workneh, F., S194

World Phytophthora Collection, screening for viruses, S116

The World Vegetable Center, overview of, S225

Wosula, E., S270

Wrather, A., S103

Wright, A. F., S194

Wright, D. L., S170, S199

WSMV. See Wheat streak mosaic virus

Wu, B., S194, S239

Wu, B. M., 340, 358

Wu, W., S272, S275

Wu, X., S150

Wu, Z., S35

Wuming, X., S148

Wunsch, M., S2.7

Wunsch, M. J., 594

Wydra, K., S6, S182

Wyenandt, C. A., S259

Xa7 resistance gene, Xanthomonas oryzae pv. oryzae on rice and, $\mathrm{S} 188$

XAC1496 gene, Xanthomonas citri subsp. citri growth and pathogenesis and, S75

XACM. See Xanthomonas axonopodis pv. citrumelo

XagP gene, Xanthomonas axonopodis and, S37

Xanthomonas spp.

on apple, S163

$X$. arboricola pv. juglandis, kasugamycin and copper or mancoxeb for management of, S2

$X$. arboricola pv. pruni on peach, S261

on Prunus spp., complete genome sequence of, S144

on Australian cedar, S200

X. axonopodis

pv. citri: on citrus, B. subtilis for control of, S76; classification of pathogenic variants of, S105

pv. citrumelo, on citrus, comparative genomic analysis of, S80

pv. dieffenbachiae, draft genome assembly of, S114

pv. manihotis, on cassava, S152, S179

pv. passiflorae, on passion fruit, 416

pv. phaseoli, on bean, S242

on soybean, virulence factors involved in $\mathrm{S} 32$

$x a g P$ and $f l i D$ mutants of, S37

$X$. campestris

pv. campestris: on crucifers, S260; new model for races of, S78

on ficus, $\mathrm{S} 26$

pv. phaseoli, on bean, 425

pv. translucens, on wheat: quick identification of, S244; yield loss in spring wheat and, S87

pv. vesicatoria, on pepper, biological control of, $\mathrm{S} 154$

pv. vitians, on lettuce, influence of cultivar on, S59

X. citri

pv. anacardii, insertion sequence- and tandem repeat-based genotyping techniques for, 887

pv. citri: on alemow, comparative host responses to narrow and broad host range strains, S84; on citrus, role of XAC1496 on growth and pathogenesis of, S75; DSF-mediated quorum sensing regulon of, S67; evaluation of chemicals and extracts for control of, S202; genes involved in biofilm formation by, S101; on grapefruit, S17, S55, S84; on kumquat, 
early activation of defense genes in, S51; on orange, cybrid response to biotic stress caused by, S55; transposon mutagenesis for identification of virulence factors, S196

pv. mangiferaeindicae, insertion sequenceand tandem repeat-based genotyping techniques for, 887

$X$. cucurbitae, on pumpkin, in Illinois, $\mathrm{S} 12$

$X$. fuscans pv. fuscans, on bean, 425

$X$. hortorum pv. carotae, on carrot, S194

microplate assay for copper resistance in, S75

$X$. oryzae

pv. oryzae, on rice: Chromolaena odorata extract for control of, 231; genetic background of $\mathrm{Xa} 7$ resistance gene and S188; genetic diversity and DNA fingerprinting of isolates from east and central Africa, S6

pv. oryzicola, genetic diversity of, $\mathrm{S} 193$

on rice, copper and, S207

X. perforans, on tomato, S269, 1217

resistance gene from pepper conferring resistance to in tomato, S237

$X$. sacchari, on sugarcane, EngA cellulase gene in asymptomatic, S96

$X$. translucens, development of molecular diagnostic markers for, $\mathrm{S} 168$

XEGIPs. See Xyloglucan-specific endoglucanase inhibitor proteins

Xi, K., S180

Xi, Y., S194

Xia, Y., S230

Xiang, H., S32, S163, S205

Xiang, K., S251

Xiang, M., S104, S194

Xiao, C., S90

Xiao, C. L., S251, 986, 1385

Xiao, Q., S194

Xiao, Y., 620

Xiaoming, P., S15

Xiaoyuan, Z., S148

Xie, C., S270

Xie, J., S83

Xie, X., 213, S233, S239

Xinfang, Z., S147

Xing, L., 878

Xing, X., S102

Xiong, R., S195

Xiong, Z., S40, S194, S199, 1136

Xiphinema spp., genetic population structure

based on mitochondrial DNA variation, 1168

Xu, D., S102, S195

Xu, J., S140, S198

$\mathrm{Xu}, \mathrm{L} ., 620$

Xu, M., S202

$\mathrm{Xu}, \mathrm{Q} ., \mathrm{S} 195$

$\mathrm{Xu}, \mathrm{S} ., \mathrm{S} 132$

Xu, X., S101, S195, S221, 392

Xu, X.-M., 1024, 1032, 1366

$\mathrm{Xu}, \mathrm{Y} ., \mathrm{S} 195$

Xue, A., S195

Xue, M., S140, S187, S198

Xue, Y., S103

Xyleborus sp. (ambrosia beetle), and Raffaelea

canadensis on avocado, S50

Xylella fastidiosa

Arabidopsis thaliana as model host for, S155

biologic and symbiotic control of using endophytic bacteria, S96

on blueberry, improving PCR-based detection of, S37

on citrus, detection and discrimination of, S135 on coffee, S276

genome-based diagnostic markers for strain differentiation, S77

on grape

alg $U$ gene and, $\mathrm{S} 165$

assessment of movement process in susceptible and resistant cultivars, 77 biofilm formation and, S141

characterization of chemosensory gene cluster in, S10

FRET probe genotyping of, S18

metabolic profiling of susceptible and resistant lines, $\mathrm{S} 107$

modeling cold curing of in California, 1492 proteomic analysis of host response to, S105 secondary metabolite and defense-related protein levels in xylem and, S185

Inc-1 plasmid of, S99

lipopolysaccharide and virulence and host specificity of, S38

on mulberry, S130

multiplication and movement in Australian native plant species, $\mathrm{S} 151$

on pear, S31, S41

on pecan, $\mathrm{S} 267$

plasmid-based expression vectors for recombinant protein production in, $\mathrm{S} 188$

role of egestion in the inoculation mechanism of foregut-borne plant pathogens and, 912

searching for sRNAs in genome, S34

synthetic gene circuits for plant-based detection of, S178

Xyloglucan-specific endoglucanase inhibitor

proteins (XEGIPs), of potato, S85

Yaacoby, T., S238

Yadav, N. V., S196

Yahyaoui, A., S226

Yajima, W., S35

Yakabe, L. E., S196

Yam. See Dioscorea spp.

Yam virus diseases, as threat to food security in

West Africa, S48

Yamada, T., S2, S55

Yamagishi, M., S43

Yamagiwa, Y., S165

Yamaguchi, I., S13, S56, S233

Yamaji, Y., 567

Yan, F., 1202

Yan, G., S196

Yan, H., S103, S196, S197

Yan, J., S103

Yan, L., S2.9

Yan, Q., S75, S196

Yan, W., 620

Yan, Y., S230

Yáñez-Morales, M., S123

Yang, B., S203

Yang, C., S39, S106, S108, S206, S251

Yang, D., S197

Yang, F., S197

Yang, H., S76, S197, S200

Yang, H.-T., 1481

Yang, J., S107, S140, S187, S197, S198

Yang, K., S100, S248

Yang, L., S105, 859

Yang, M.-M., 1481

Yang, N., S185

Yang, P., S187

Yang, W., S199, 1217

Yang, X., S45 S148, S197, S200

Yang, X. B., S2.4

Yang, Y., S71, S91, S108

Yasuda, F., 316

Ye, X., 1264

Yeasts, grape sour rot and, S189

Yeater, K., S7

Yeh, S., S35, S140, S198

Yeh, S.-D., 367

Yellow shoot disease. See Candidatus Liberibacter asiaticus

Yellow starthistle. See Centaurea solstitialis

Yeo, K.-H., 1492

Yilma, S., S190

Yim, K., S36

Yin, C., S198, S208

Yin, J., S79
Yin, K., S194

Yin, L., S106

Yin, N., 986

Yoder, J., S239

Yoder, K., S80

Yoder, K. S., S114, S274

Yokomi, R. K., S43

Yokota, K, S95

Yolageldi, L., S65

Yoneyama, K., 213, S233, S239

Yoon, J., S198, S199

Yoon, Y., S100, S198

Yoshimoto, E., 575

Yoshimura, A., S188

Youm, O., S216

Young, C., S53, S174

Young, H., S19, S54, S125

Young, H. M., S199

Young, R., S232

Young, S., S208

Young, W., S31

Yu, J., S32, S163, S205, 1322

$\mathrm{Yu}, \mathrm{K} ., \mathrm{S} 230$

Yu, N., S199

Yu, T., S35

Yu, X., S83

Yu, Z., S103

Yuan, H., S102

Yuan, M., S207

Yuan, Q., S199

Yuen, G. Y., S199, S200

Yuen, J. M., S130

Yuh, J. P., S94

Yun, H., S100

Yun, S., S200

Yuttavanichakul, W., S200

Zacaroni, A., S174, S200

Zamanizadeh, H., S88, S112, S142, S150, S169, S175

Zambino, P., S111, S248, S249

Zang, R., S251

Zanthoxylum alatum, essential oil from for control

of pinewood nematode, S137

Zapata, M., S276, S279

Zapata, N., S162

Zaragoza, W., S200

Zasada, I., S209

Zasada, I. A., 480

Zayas Garcia, E. J., S255

Zea mays (corn) aflatoxins, cyclopiazonic acid, and fumonisins in, reduction of by biocontrol strains of Aspergillus flavus, S1

arrested ear development in, foliar-applied pesticides and surfactants and, S2.8

Aspergillus spp. on

A. flavus: comparison of soil and kernel populations, 952; detection and identification of using solid-phase microextraction, S269; detection of aflatoxin-producing isolates, S193; evaluating resistance using stem inoculations, S193; gene expression profile and response to kernels, 797; genetic diversity within vegetative compatibility group of, S250; in Mexico, aflatoxin contamination and, S181; at varying elevations in Mexico, S133

A. niger, endophytic associations and mycotoxin production, $\mathrm{S} 135$

proteins associated with aflatoxin resistance in, S21

Cercospora zeae-maydis on

abscisic acid production by, $\mathrm{S} 44$

foliar fungicides for control of, S242

genes involved in foliar infection, $\mathrm{S} 72$

quinone outside inhibitor fungicides and, S31

Clavibacter michiganensis ssp. nebraskensis on, commercially available tests for, S2.5 
Curvularia lunata on

differential proteins and genes induced by resistant germplasm, S33

genetic differentiation and resistance evaluation, $\mathrm{S} 147$

Diabrotica virgifera on, S182

ear molds and mycotoxins in North Dakota (2009), S244

earworm on, S169

Exserohilum turcicum on, S148, S252

fall armyworm on, S169

foliar fungicide application on, profitability of in Illinois, S189

Fusarium spp. on

drydown rates, environmental factors, and resistance, $\mathrm{S} 251$

mycotoxins associated with in South Africa, S18

F. oxysporum f. sp. vasinfectum, root-knot nematode and, S270

role of mycotoxins in seedling infection and, $\mathrm{S} 22$

F. verticillioides: association between isolates from, S88; genetic diversity of $\mathrm{S} 88$; B. mojavensis for control of, $\mathrm{S} 12$; movement of fungus, fumonisins, and biomarkers of exposure, S206

identification of pathogens causing root rot diseases of in China, S82

injection of insecticides in silk channels for management of lepidopteran pests of, S169

Maize mosaic virus in, Peregrinus maidus fitness and wing morphology and, S72

Maize streak virus in, S158

maize wallaby ear symptoms on, cultura control of, S116

Meloidogyne incognita on, Fusarium oxysporum f. sp. vasinfectum and, S270

meta-analysis of yield response to foliar fungicides, 1122

multiple viruses in, Wsm genes and, S151

nematodes on

comparison of methods for extracting, S2.1 distribution and abundance in Illinois, S110

northern corn rootworm in, S55

Pantoea stewartii subsp. stewartii on oxidative stress response, virulence, host colonization and, S23

PCR primers for detection of, S16

perception by growers and consultants on

importance of diseases of, S50

Physoderma maydis on, S93 planting date and weed management in, S181

previous crop history and response to foliar fungicides in, S242

Puccinia polysora on, strategies for management of in Georgia, S9

pyraclostrobin foliar fungicide application and harvest timing and, S2.8

Pythium spp. on, S173

Rhizoctonia solani on, sedaxane for control of, $\mathrm{S} 132$

Rice black-streaked dwarf virus in, S82

southern corn rust and, S266

spatial and temporal patterns of insect damage and aflatoxin on, S128

Ustilago maydis on, drydown rates, environmental factors, and resistance, S251

weed control with flaming and cultivation, S91

Zearalenone, Fusarium spp. on corn and, S18

Zebra chip disease. See Candidatus Liberibacter solanacearum

Zebra grass. See Miscanthus sinensis

Zee, F., S89

Zehr, U. B., 367

Zemetra, R., S59

Zeng, H., S148, S200

Zeng, J., S103

Zeng, Q., S206, S208

Zerbini, F. M., S104, S166

Zerillo, M. M., S201

Zeun, R., S133

Zhai, J., S150

Zhan, G., S201

Zhang, A., S203

Zhang, C., S139

Zhang, C. L., 377

Zhang, D., S66, S272, 1322

Zhang, G., S132, S203

Zhang, G. R., S203, S246, S267, S2.9

Zhang, H., S185

Zhang, J., S195, S201, S203, S207, 859

Zhang, L., S44, S83

Zhang, M., S202, S203

Zhang, M. Q., 1097

Zhang, N., S123, S129, S202, S204, S211

Zhang, R., S203

Zhang, S., S120, S202, S204, S270

Zhang, T., S107, S202

Zhang, X., S66, S189, 1264

Zhang, Y., S107, S198, S199, S201, S202, 1081

Zhang, Z., S43, S44, S51, S203, S2.3

Zhao, B., S209

Zhao, C., S197
Zhao, F., S88

Zhao, M., S2.6

Zhao, S., S202, S204

Zhao, W., S187, S198

Zhao, X., S107, S189, S195, S204

Zhao, Y., S102, S186, S197, S214, S272, S273,

S275, 710

Zhao, Y. F., S118

Zhao, Z., S186

Zheng, D., S23

Zhiqiang, C., S148

Zhiyong, Z., S84

Zhong, S., S5, S146

Zhongqi, H., S132

Zhou, C., S204, S205

Zhou, J., S178, S206, S207, S270

Zhou, L., S73, S145, S205

Zhou, L. J., 1097

Zhou, Q., S77

Zhou, S., S208

Zhou, T., S82, S205

Zhou, X., S82, S204, S205, S207, S270

Zhou, X. G., S50, S204, S205, S270

Zhou, Y., S26, S82, S189, S195, S205

Zhou, Z., S185

Zhu, S., S34

Zhu, X., S251, S252

Zhu, Y. J., S82

Zhuang, X., S2.9

Zhuo, K., 1270

Ziegler, D., S145

Zinc-finger effectors, plant cell death, immunity, Magnaporthe oryzae and, S108

Zingiber officinale (ginger), Ralstonia solanacearum on, $\mathrm{S} 124$

Ziska, L. H., S240

Zitomer, N. C., S206

Zizania palustris (wild rice), Cochliobolus miyabeanus on, $\mathrm{S} 29$

zNose technology, for detection of Burkholderia cepacia on onion, S189

Zou, H., S206

Zou, L., S206

Zoxamide, Phytophthora capsici and, 1104

Zuñiga, F., S254

Zuñiga, L., S162

Zucchi, M. I., 416

Zucchini. See Cucurbita pepo

Zühlke, S., S18

Zuluaga, P., S261

Zuo, R., S102

Zydenbos, S. M., S224 